Historic, Archive Document

Do not assume content reflects current scientific knowledge, policies, or practices. 
I 
Unted States 23

Department of

Agrlculture

Forest Senvice

Alaska Region

February 1994

R10-MB-253

霆

THE

졸

CHUGACH

NATIONAL

FOREST

AND

ITS PARTNERS

ALASKA

1993 
If you are interested in becoming a partner with the Chugach National Forest, please contact any of the following offices:

Forest Supervisor's Office Chugach National Forest 3301 "C" Street Suite 300 Anchorage, Alaska 99503

Glacier Ranger District Chugach National Forest P.O. Box 129

Girdwood, Alaska 99587

Seward Ranger District Chugach National Forest P.O. Box 390 Seward, Alaska 99664

Cordova Ranger District Chugach National Forest P.O. Box 280 Cordova, Alaska 99574 We look forward to hearing from you. 


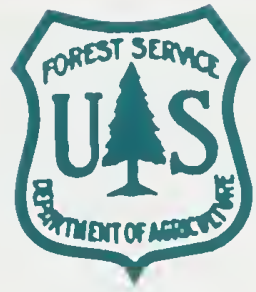

The
Chugach National Forest
and It's
Partners

The USDA Forest Service is responsible for the stewardship of America's National Forests. We are working to accomplish this goal with the active involvement of many private and other public sector partners. Our management of your national forest is immeasurably enhanced through the assistance of others.

Alaska's Chugach National Forest is bringing together private companies, organizations, agencies, and individuals to help manage the nation's second largest national forest (5.6 million acres). In 1993, 100 different partners contributed more than $\$ 1,000,000$ to help us provide goods and services to Americans and visitors from around the world.

These pages describe the many ways our partners have so unselfishly contributed to the American people by helping us manage the Chugach National Forest.

This publication is dedicated to our partners. 



\section{Table of Contents}

Recreation

2

3

$4-5$

6

7

8

9

10

11
Recreation Opportunities Along the Seward Highway Scenic Byway .Russian River Angler Trail "A Plan for Recovery"

National Trails Day

Backcountry Trail Maintenance Cordova International Volunteer Month Appalachian Mountain Club Service Trips Cordova Community Work Service Boyscouts - Susitna Council Coghill Trail Update
13

14

15

16

17

18

19

20

21

22

23

24

25

26

27

28
Cooper Landing Small Mammal Monitoring Kenai Peninsula Alpine Range Enhancement Crescent Mountain Moose/Sheep Habitat Improvement Seward Bear Awareness Program Bald Eagle Nesting Survey Kenai Peninsula Cooperative Wolverine Project Kenai Peninsula Cooperative Brown Bear Model "Give Moose A Brake" Cooperative Project Neotropical Bird Monitoring Project Audubon Christmas Bird Survey Kachemak Bay Shorebird Festival Prince William Sound Mountain Goat Survey .Copper River Delta Moose Habitat Study Sitka Black-Tailed Deer Survey Dusky Canada Goose Nest Plot Surveys Bering Lake Trumpeter Swan Study Evaluation of Body Condition Indices for Assessing Nutritional Status of Moose on the Copper River Delta Population Dynamics of Gray Wolves on the Copper River Delta Physiology of Migration in Western Sandpipers Migratory Shorebird Staging on the Copper River Delta .Copper River Delta Aerial Moose Survey .Copper River Waterfowl Surveys District Inventory and Monitoring Neotropical Migratory Bird Monitoring Moose Winter Ecology Turnagain Arm Marine Mammal Stranding Network 
40

41

42

43

44

45

$46-47$

48

49

50

51

52

53

54

55

56
.Twentymile River \& Placer River Sport Fisheries Management Plan Kenai Small Lakes Resident Sportfish Development . Resurrection Creek Fisheries Habitat Restoration Resident Lake Cutthroat Study Mile 18 Cutthroat-Dolly Varden Study Fishway Maintenance and Monitoring Mile 18 Creek Basin Wild Habitat Survey and

Coded Wire Tagging Project Mile 25.25 Spawning Channel Sheridan Habitat Structures American Fisheries Society Coho Salmon Habitat Workshop Monitoring Fishing Pressure Explorer Creek and the Railroad Ponds System in Portage Valley Portage Valley Youth Fishing Days Portage Valley Resident Sportfish and Wild Salmon

Habitat Development Western Prince William Sound Fishway Maintenance and Monitoring Girdwood Valley Fish Monitoring Project Coghill Lake Cooperative Fertilization and Sockeye

Salmon Enhancement

\section{Natural Resource Conservation Education}

58

59

60

61

62

63

64

65

66

67

$68-69$

70

71

$72-73$
.Chugach Region Elder-Youth Conference .District Natural Resource Education .Arbor Day Tree Planting Program Kids Fishing Day Environmental Awareness Days Seward Parks and Recreation Day Camp .Cordova Science Club Natural Resource Conservation Education for Prince William Sound National Resource Conservation and Environmental Education Programs (Special Groups and Events) .National Resource Conservation and Environmental

Education Program (Schools) .Cordova Discovery Room Kids Fishing Derby International Migratory Bird Day 4-H Forestry Camp 


\section{Public Information and Interpretation}

Search for Historic Russian Plates in Prince William Sound

.Tern Lake Wildlife Viewing Platform Monofilament Fishing Line Recycling Program Russian River/Kenai River Catch and Release

Rainbow Poster

Moose Creek Fish Viewing Platform Fisheries Habitat Mitigation on Highway Realignment Projects

$81-82$

83

84

85

86

87

88

$89-90$

91

92

93

94

95

96

97

98
Kenaitze Indian Tribe Interpretation Site .Providing Public Sweet Smelling Toilet ..World Explorer Cruises .Connections" - A Museum Exhibit Watchable Wildlife Placemats Transport Cabin Maintenance on Resurrection Pass Trail Watchable Wildlife Radio Series .Copper River Delta Shorebird Festival .Copper River Delta Media Projects A Workshop on Critical Forest Habitats and Long-Term Planning in the Prince William Sound Area Forest Interpreters on the M/V Ptarmigan .Forest Interpreters Staff Alaska Marine Highway System Ferries Prince William Sound Tourism Association .Chugach State Park Alaska Natural History Association Student Conservation Association

\section{Minerals, Vegetation, and other Partnerships ............99}

100

101

102

103

104

105

106

107

108

109

110
.The Role of Equisetum in Phosphorus Cycling and Net Primary

Productivity on the Copper River Delta .The Role of Nitrogen Fixation in Copper River Delta Ecosystems .Modeling Primary Productivity in the Copper River Delta Ecosystem . Assessing the Dynamics of Natural Resource Development in

Prince William Sound .Ecological Classification and Mapping of the Copper River Delta ..Wetland Vegetation Classification of the Copper River Delta Rutgers University Study Trip Southern Zone Logistics Office Interagency Airtanker ..KAKM Channel 7 Interagency Fire Helicopter 
i

ii.....

Recreation Wildlife $\checkmark$ Fisheries viii $\mathrm{xi}$ Natural Resource Conservation Education Public Information and Interpretation xvi Minerals, Vegetation, and other Partnerships 
RECREATION 


\section{The Project}

\section{RECREATION OPPORTUNITIES ALONG THE SEWARD HIGHWAY SCENIC BYWAY \\ SEWARD RANGER DISTRICT}

\section{The Partners}

Their Contributions

Cook Inlet Aquaculture (CIAA) $\$ 3,000$

Seward Chamber of Commerce (SCC) $\$ 10,000$

Chugach National Forest (Fisheries \& Recreation) $\$ 8,000$

\section{The Benefits}

- interpretive display

- highly visible example of Forest Service Partnership

\section{The Work}

Funding for the FY '93 President's Initiative program was used to develop a first class, professional display to profile the many recreational opportunities the Chugach National Forest offers visitors travelling along the Seward Highway Scenic Byway. Forest graphic artist, Kathy Sarns, designed a computer generated district map which will direct visitors on where to enjoy a variety of activities in the Chugach, accessible from the Seward Highway Scenic Byway, such as hiking, camping, fishing, salmon, and wildlife viewing. In 1994, the display will be posted at the Seward District Office, the Seward Boat Harbor, and the Marine Highway Ferry Office. The map will also be displayed at the Cook Inlet Aquaculture's Trail Lake Hatchery and Bear Lake Weir along with information on CIAA's fisheries enhancement programs and the Seward Chamber of Commerce to promote visitor activities in the Seward area. Cook Inlet Aquaculture Association constructed the Bear Lake Weir Kiosk with grant money SCC acquired from the Alaska Department of Fish and Game's Sportfish Development Program. 


\section{The Project}

\section{RUSSIAN RIVER ANGLER TRAIL \\ "A PLAN FOR RECOVERY" \\ SEWARD RANGER DISTRICT}

Cook Inlet Region, Inc. (CIRI)

Kenaitze Indian Tribe

National Marine Fisheries Service

Alaska Department of Fish and Game Alaska State Parks
U.S. Fish and Wildlife Service

Kenai River Sport Fishing Association

Alaska Flyfishers

Alaska Sportfishing Association

Rutgers University undergraduate student

(All partners are providing donated time - approximately six person days per partner)

\section{The Benefits}

- multi-agency plan for rehabilitation of the Russian River area

- project will serve as a model for resource and visitor management

in high-use fisheries areas.

\section{The Work}

During the sockeye salmon runs, the Russian River is the most heavily fished stream in Alaska. Much of the access to fishing is via the Russian River angler's trail leading from the Forest Service Russian River Campground. Heavy angler use along the trail has resulted in trampling of streamside vegetation and compaction and erosion of streambank soil. An existing multi-agency working group was expanded in September 1993 to include members of the public, CIRI, Kenaitze Indian Tribe, and various fishing organizations. This group continues to identify issues and develop alternatives that will solve the problems identified in the Russian River area.

The goal of the plan is to rehabilitate streambanks and protect fish habitat. In addition, working group members are helping

Eroded soils at the Russian River expose tree roots an interpretive plan with some members volunteering to educate anglers during the summer of 1994 about reducing their impact on the Russian River ecosystem.

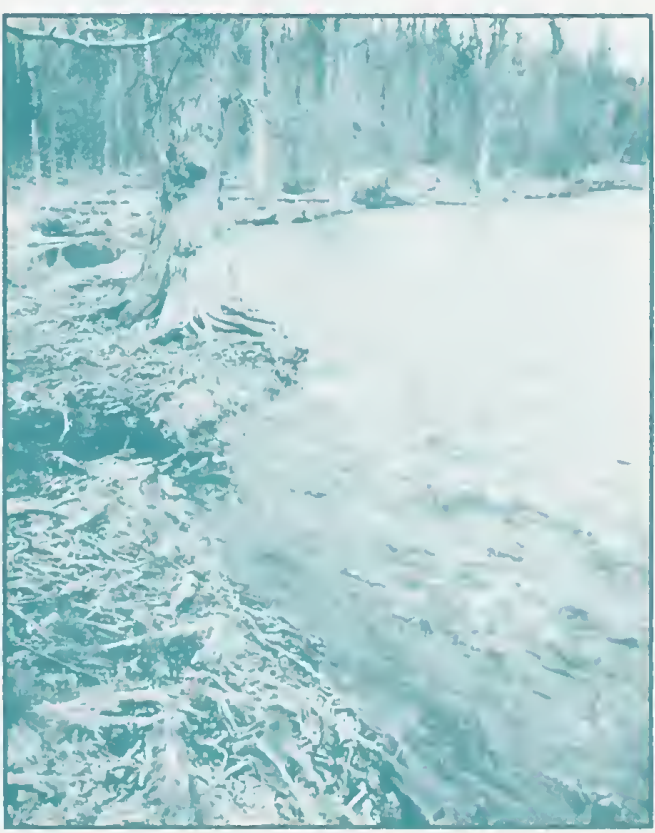


The Project

\section{National Trails DaY \\ SEWARD RANGER DISTRICT}

The Partners

Their Contributions

Arctic Mountain Bike Club (18 members and bikes) (In-kind) $\$ 1,260$

REI provided equipment and space in their

Anchorage store for the Forest Service program (In-kind) $\$ 200$

Chugach National Forest (salary) $\$ 800$

20 Kenaitze Indian Tribal Youth and 12 participants

from the public gained appreciation for trails.

\section{The Benefits}

- accomplished 161 volunteer hours of trail maintenance on three projects.

- participants gained a greater appreciation for trails and the amount of work required to maintain them.

- increased potential for future partnerships with volunteer groups.

- educated more people (REI presentation) in NO-TRACE backcountry ethics.

\section{The Work}

June 5, 1993, was the first celebration of National Trails Day across the Nation.

This special day was set aside to bring together trial users, to draw attention to the importance and value of Trails for All Americans. National Trails Day commemorates the 25 th anniversary of legislation passed in 1968 for the National Trails System Act.

The Seward Ranger District had a very successful and fun day.

Fifty-five volunteers and 12 Forest Service employees participated in a wide range of activities. In addition, two Forest Service employees spent the evening of June 17, at REI in Anchorage giving a NO-TRACE camping presentation and information on the District's hiking trails to 13 people.

Anne Jeffery, (SO Public Affairs), arranged for several Public Service Announcements which were aired on Seward and Anchorage radio stations, and newspaper articles in the Anchorage Daily News and Kenai Peninsula Newspapers. 
1. Gull Rock Hike - This was a ten mile family hike along Tumagain Arm to Gull Rock. The District offered free camping at Porcupine Campground (trailhead is located in the campground) on June 4 and 5. Twelve hikers joined Forest Service representatives Deidre St. Louis (recreation staff officer) and Katie Toth-Stauble (interpreter).

2. Russian Lakes and River Hike - This was a six mile hike on the Lower Russian Lakes trail to the falls, and down the Angler's trail.

Twenty Kenaitze Tribe members joined Forest Service representatives Irene B. Lindquist (Trails Technician), Eric Clarke (Trail Ranger), and two Llamas packing lunch.

3. Carter Lake Bridge - A planked bridge was built over a creek which drains into Carter Lake. Abuttments using gabions and gabion bags needed to be built also.

Five volunteers joined Forest Service representatives Steve Hennig (SO Recreation), Robin Kling (Trail Crew Leader), and Todd McCann (Trail Crew Member).

4. Johnson Pass Trail Maintenance - Ditch and culvert maintenance was accomplished on the north end of this trail. Mountain bike riders rode 12 miles round trip. Tools were strapped to the bikes.

Fourteen mountain bike riders (many from the Arctic Mountain Bike Club) joined Forest Service representatives Jim Rosauer (Trail Ranger), Stephen Hmurciak (Trail Crew Supervisor), and Lisa Wolcott (Trail Crew Member).

5. Resurrection Pass Trail Maintenance - Ditch and culvert maintenance was accomplished on the North end of this trail. Mountain bike riders rode eight miles round trip. Tools were strapped to the bikes.

Four mountain bike riders (Arctic Mountain Bike Club Members) joined Forest Service representatives Patrick O'Leary (Recreation Planner) and Dan Hubbard (Trail Crew Member).

6. No-Trace Camping Presentation - A slide program on NO-TRACE camping was given at REI in Anchorage.

Thirteen people came to listen to the presentation given by Forest Service employee Nancy Gehm (Interpreter). Irene B. Lindquist (Trails Technician) answered questions about hiking trials on the Seward Ranger District. 


\section{The Project}

\section{BaCKCOUNTRY TRAIL MaINTENANCE \\ SEWARD RANGER DISTRICT}

\section{The Partners}

Their Contributions

\section{Shawn Lyons, Outdoor Writer for}

Anchorage Daily News

In-kind(salary) $\$ 500$

\section{The Benefits}

- Shawn Lyons wrote a feature article for the Anchorage Daily News which described the work he did with the Forest Service trial crew. The article helped inform the public about what

Forest Service trail crews do - what the work is and the difficulty of the work.

- two days worth of backcountry trail maintenance was accomplished by Mr. Lyons.

\section{The Work}

On July 29-30, 1993, Shawn Lyons assisted a Seward Ranger District trail crew with backcountry trail maintenance on the Resur- rection River and Russian Lakes Trails. Work was mainly clearing overgrown brush from the trails. 


\section{The Project}

\section{CORdOVA INTERNATIONAL VOLUNTEER MONTH CORDOVA RANGER DISTRICT}

The Partners

Volunteers for Peace International Volunteers Chugach National Forest
Their Contributions

In-kind $\$ 10,400$ $\$ 18,000$

\section{The Benefits}

- 450 feet of an accessible boardwalk constructed

- 160 feet of new trail constructed

- built four hardened interpretive sites

- constructed two staircases

- .8 miles of trail maintenance

\section{The Work}

From July 1 - July 30, 1993, 11 volunteers from around the world took part in the second annual Cordova International Volunteer Month. The goal of this program was to respond to those individuals-both U.S. and foreign-willing to volunteer their time, energy, and skills, while at the same time, providing them a unique, and culturally diverse experience.

The 11 volunteers form Czechoslovakia, France, Germany, Finland, Canada, and the U.S., spent four weeks of hard work constructing an accessible boardwalk at Alaganik Slough and reconstructing an interpretive trail on the Cordova Ranger District. They com-

Alaganik boardwalk provides an accessible path into the spectacular wetlands of the Copper River Delta. pleted 450 feet of boardwalk maintenance and reconstruction on .8 miles of trail.

The International Volunteer Month was a great success and all involved have many fond memories of the experience. The Cordova Ranger District will continue the program in 1994.

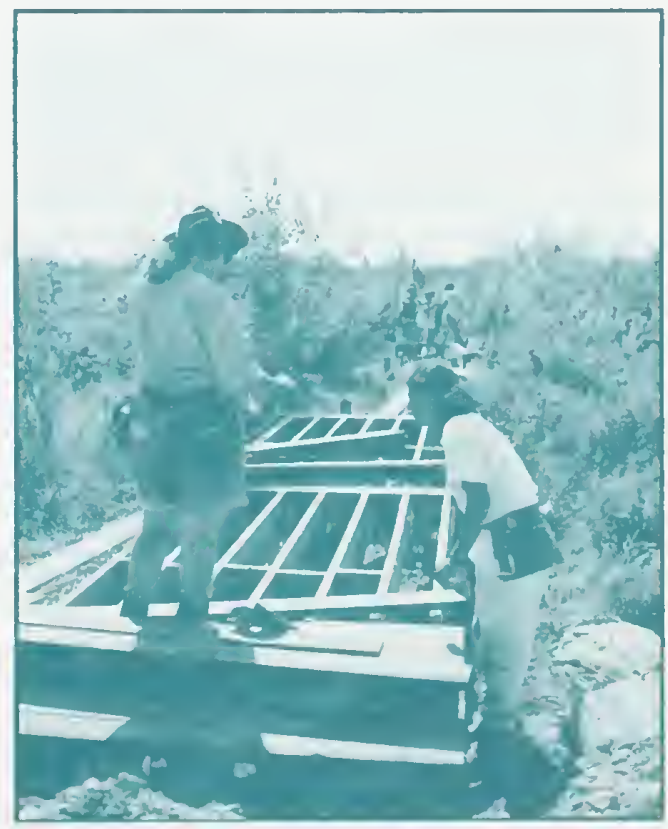




\section{The Project}

\section{Appalachian Mountain Club Service Trips CORDOVA RANGER DISTRICT}

Appalachian Mountain Club (In-kind) $\$ 7,040$

Chugach National Forest $\$ 5,800$

\section{The Benefits}

- 200 feet of an accessible boardwalk constructed

- 560 feet of trail reconstructed

\section{The Work}

This program ran for two 10-day periods in late August and early July 1993. The Appalachian Mountain Club (AMC) adverstised the program to its members and selected five volunteers for each trip. Two group leaders were also chosen by AMC and were in charge of the logistics of the trip, purchasing food, and leading the group in work projects. The Forest Service paid for food for the volunteers during the 10-day periods, air fare for the leaders to get to Cordova, and a fee to AMC for each trip.

Alaganik boardwalk provides an accessible path into the spectacular wetlands of the Copper River Delta.
The AMC volunteer program has been operating on the Cordova Ranger District since 1986. During the past seven years, AMC has donated much time and energy to the Cordova Ranger District. With their help, the Power Creek/Crater Lake Loop Trail (12 miles) and the Power Creek Basin Trail have been completed.

The 1993 AMC volunteer groups completed 200 feet of an accessible boardwalk at Alaganik Slough recreation area and 560 feet of trail reconstruction on Haystack Watchable Wildlife Interpretive Trail.

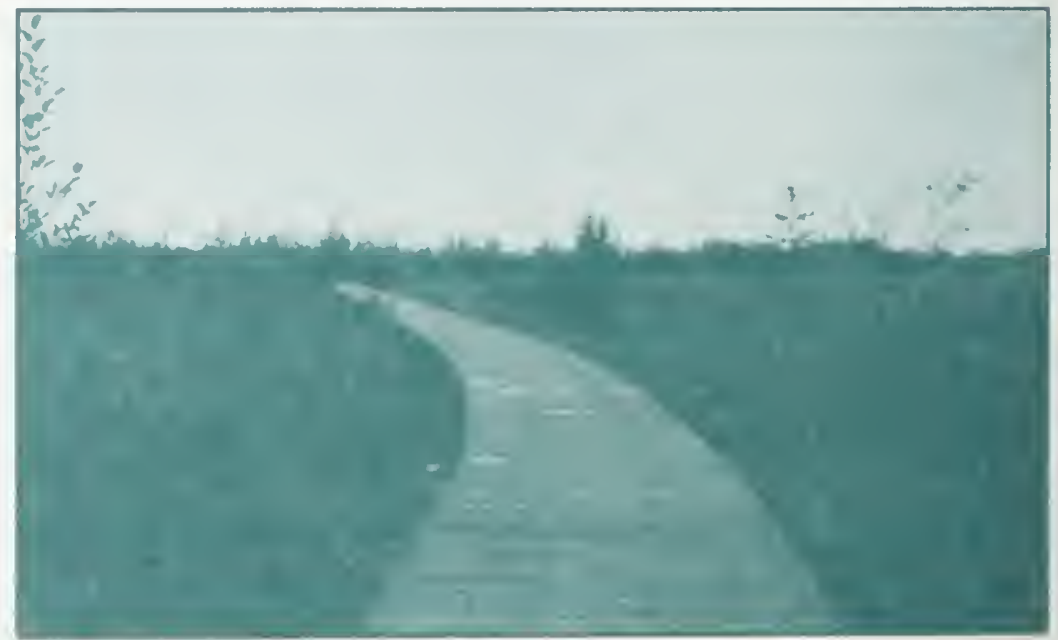




\section{The Project}

\section{Cordova Community Work SERvice CORDOVA RANGER DISTRICT}

\section{The Partners}

\section{Their Contributions}

Alaska Court System .040 hours volunteered Chugach National Forest In-kind

\section{The Benefits}

- volunteer labor for national forest projects

\section{The Work}

This is the second year that the Cordova Ranger District has worked with the Alaska Court System on this program. The court system had several local people who needed to complete community service.
During the summer, three individuals were assigned by the court system to work with the Cordova Ranger District to assit the district's trail crew and perform maintenance work at the district office. 


\section{The Project}

\section{BOYSCOUTS - SUSITNA COUNCIL \\ GLACIER RANGER DISTRICT}

\section{The Partners}

Their Contributions

Boyscouts - Susitna Council

$\$ 16,000$

Chugach National Forest

$\$ 1,050$

\section{The Benefits}

- improved two ski trails in Turnagain Pass

\section{The Work}

Two separate projects helped to improve two ski trails in the Turnagain Pass area. The first project was organized by a scout working on his eagle badge. He led the effort to get other scouts to help clear and install markers on the trail up Tin Can. The second project was a major camp-out for the enitire council, work was done on both Tin Can and Center Ridge Trails, clearing and marking. 


\section{The Project}

Coghill Trail UPDate

GLACIER RANGER DISTRICT

The Partners

Their Contributions

Sierra Club

(in labor) $\$ 12,000$

Chugach National Forest

$\$ 2,250$

\section{The Benefits}

- improving the relationship between the Forest Service and the

Sierra Club, building a trust level

\section{The Work}

The Sierra club worked with the Glacier

Ranger District to improve the Coghill Trail for the past two summers. Work included moving trail out of the muskeg onto drier ground to minimize boardwalk sections. 

WILDLIFE

Partners Partners Partners Partners Partners Partners Partners Partners Partners Partners Partners Partners 


\section{The Project}

\section{CoOper Landing Small Mammal Monitoking SEWARD RANGER DISTRICT}

\section{The Partners} Their Contributions

Rutgers University 88 hours volunteered

\section{The Benefits}

- conduct small mammal responses to beetle epidemic

\section{The Work}

The group of natural resource students from Rutgers University spent a day of their field trip to Alaska. They assisted district biologist in setting up and conducting small mammal survey, using live box traps. This ongoing program is designed to monitor small mammal populations as the vegetation changes because of the spruce beetle epidemic. 


\section{The Project}

\section{Kenai Peninsula Alpine Range Enhancement \\ SEWARD RANGER DISTRICT}

\section{The Partners}

Their Contributions

Alaska Department of Fish and Game ............................................................\$2,000

Sixty-Thirty North ..................................................................................................\$\$2,000

Foundation for North American Wild Sheep .................................................\$2,000

The Benefits

- 3,500 winter range acres surveyed

The Work

Dall sheep and mountain goat populations have declined on the Kenai Peninsula in the past years. In response, the Seward Ranger District is conducting winter range trend and condition surveys to provide long-term population and habitat information. Fertilizer test trials initiated in 1990 are nearing final analysis. This information will be used to develop new range enhancement methods while additional sites are being evaluated for prescribed burning beginning in 1994.

This project will improve sheep and goat winter ranges on the Kenai Peninsula, resulting in better watchable wildlife opportunities.

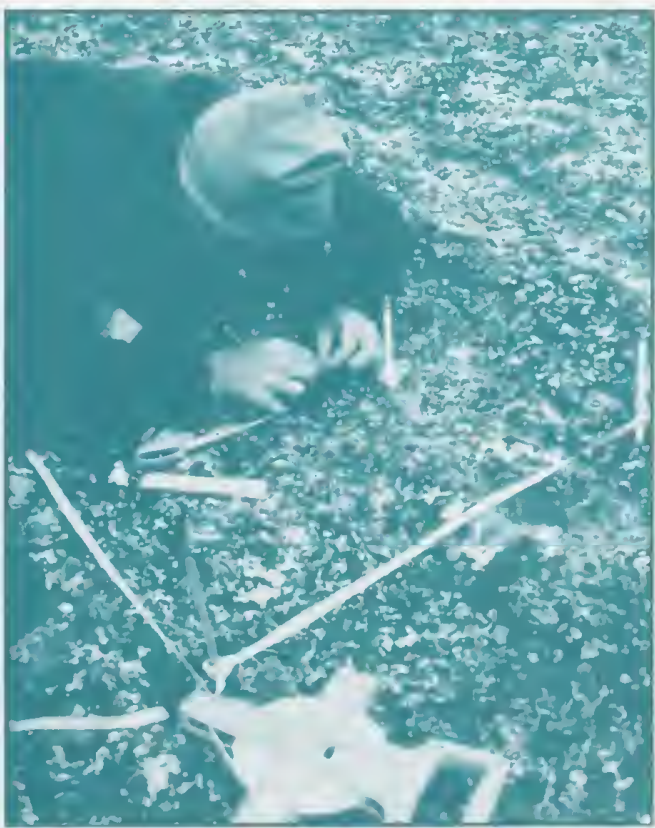




\section{The Project}

\section{Crescent Mountain Moose/ Sheep \\ HABITAT IMPROVEMENT \\ SEWARD RANGER DISTRICT}

\section{The Partners}

Their Contributions

Foundation of North American Wild Sheep................................................\$2,000

Sixty-Thirty North ................................................................................(In-kind) \$500

\section{The Benefits}

- increased forage for wintering moose and Dall sheep thru a prescribe burn.

\section{The Work}

The Forest Service, with financial assistance of NFAWS and with the flying and filming of Sixty-Thirty North Flying Service, burned 1500 acres of winter range for moose (in lower elevations) and sheep in the upper elevations along Kenai Lake. Using a helicopter, district personnel lit the existing vegetation of dead spruce, large birch, and alder. Within weeks of the burn, survey crews found dense resprouting of harwoods and berry producing plants and a new stand of grass in the upper slopes.

This project improves not only hunting but a variety of watchable wildlife and natural resource education opportunities as well.

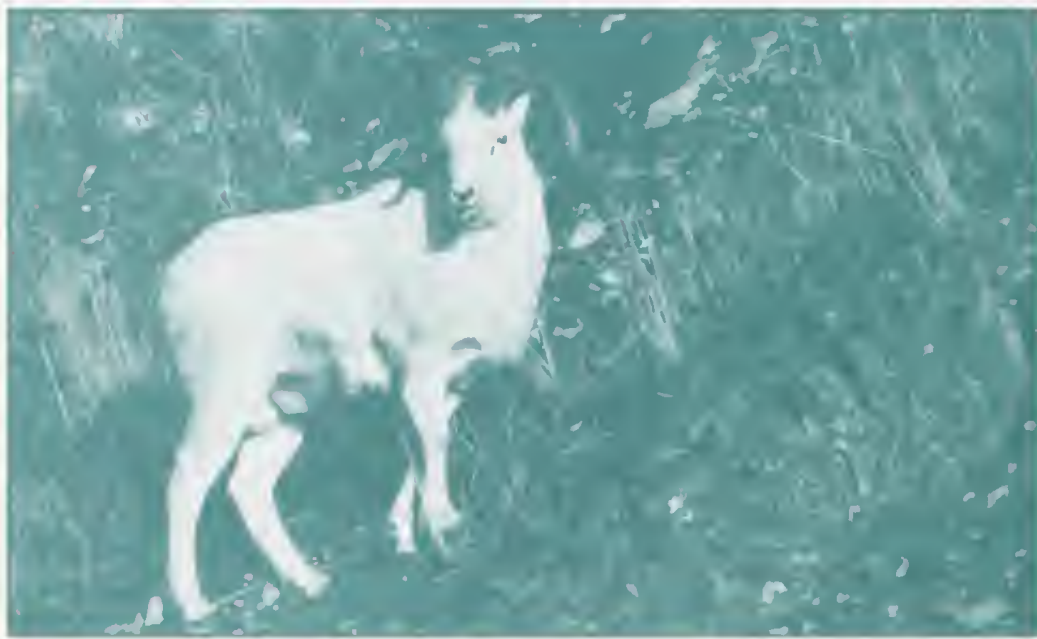




\section{The Project}

\section{Seward Bear Awareness Program \\ SEWARD RANGER DISTRICT}

\section{The Partners}

Their Contributions

Kenai Fjords National Park $\$ 2,000$

Alaska Fish Wildlife Protection $\$ 2,000$ City of Seward (In-kind) $\$ 500$

\section{The Benefits}

The objective of the program was to reduce the threat of bear encounters through an intensive education program aimed at both local residents and visitors, and through improved garbage containment and compliance.

The piece de resistence was Bear Fair on April 24. Close to 100 people came to the fair, featuring Native Bear Tales, a puppet show, and a bear slide show showing how to avoid bear problems.

\section{The Work}

During the summer of 1992 , there was a record number of bear incidents in the town of Seward and at National Forest campgrounds. A community education and action project was created because of the number of deaths to the bears and because of the threat to public safety. Among the members of the committee were Department of Public Safety, Fish and Wildlife Protection, Kenai Fjords National Park, Seward Police Department, and the Seward Ranger District.

Don't Trash Seward's Bears was the title of the program. Numerous newspaper articles were printed and a travelling panel display made the rounds around the community to educate and remind people of the problem. The Seward 6th grade and High School students were involved in research and education projects to assist with the program.
An amateur art contest was also run to design a logo for the project.

Trashy the Bear spent much of the day outside the Senior Center encouraging people to come in and see the show.

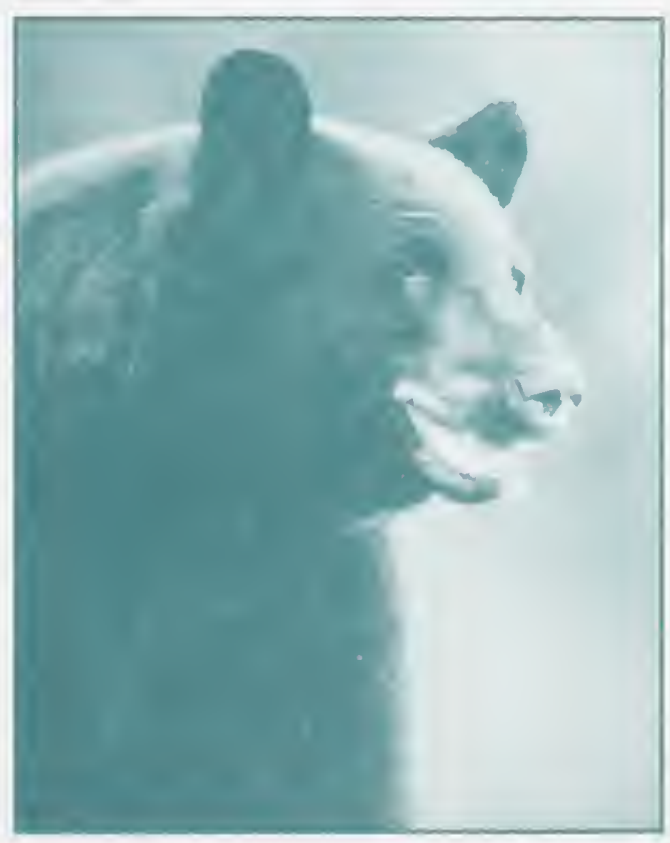




\section{The Project}

\section{Bald EAgle Nesting Survey \\ SEWARD RANGER DISTRICT}

\section{The Partners}

Their Contributions

U.S. Fish and Wildlife Service (In-kind) $\$ 500$ Chugach National Forest $\$ 500$

\section{The Benefits}

- conduct annual eagle nesting survey

\section{The Work}

With assistance from the U.S. Fish and Wildlife Service, the Forest Service flew and surveyed all known bald eagle nests in the

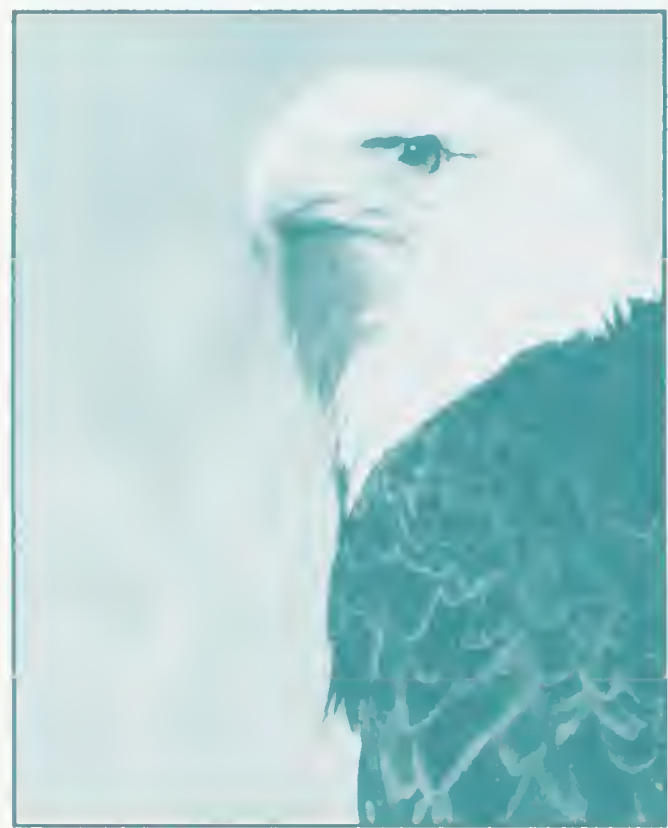

Seward Ranger District area. Several new nests were found and marked as a result of these flights. The bald eagle are monitored each year to determine nesting success.

Adult Bald Eagle 


\section{The Project}

\section{Kenai Peninsula Cooperative Wolverine Project SEWARD RANGER DISTRICT}

\section{The Partners}

Their Contributions

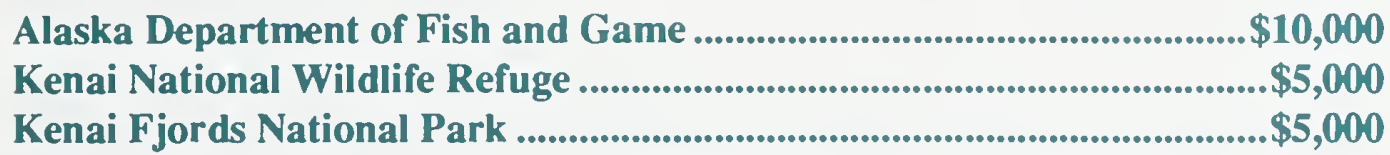

The Benefits

- 50,000 acres wolverine winter range surveyed

\section{The Work}

The wolverine harvest has been closed in Game Management Unit (GMU), 15C as a result of low trapper success and the reduced number of wolverine or wolverine track sightings in the last few years. Since wolverines are wilderness species and require huge tracks of land for home ranges, the investigation of this decline is being conducted on a landscape basis. Aerial surveys will be flown in two successive years by the four cooperating agencies that manage the area surrounding
GMU $15 C$ to develop a population index. If this phase of the project is successful, a more detailed demographics survey will be undertaken.

Benefits of this project include potential for the "Eyes on Wildlife" program and natural resource education opportunities involving wolverine, as well as improved wolverine habitat and population management techniques. It also highlights the increasing need for cooperative management of certain wildlife species by all involved agencies. 


\section{The Project}

\section{Kenai Peninsula Cooperative Brown Bear Model SEWARD RANGER DISTRICT}

The Partners

Their Contributions

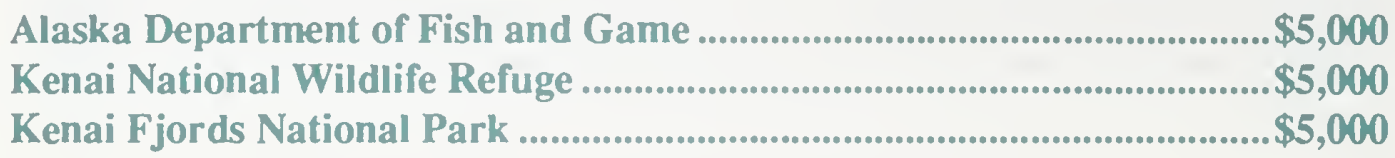

\section{The Benefits}

- brown bear habitat effectiveness model

The Work

The Kenai Peninsula brown bear population is, for management purposes, considered an island population. Habitat loss and degradation due to increasiring human development (coupled with danger to life and property), killing, and sport harvest are producing increased pressures on the population. As additional development and land management activities are planned, the need for a habitat effectiveness model has become apparent. Because brown bear are such wide-ranging animals and cross many jurisdictional boundaries, the modeling effort has been undertaken in an interagency manner. A rough draft of the habitat effectiveness model has been completed and will be ready for field validation in 1994.

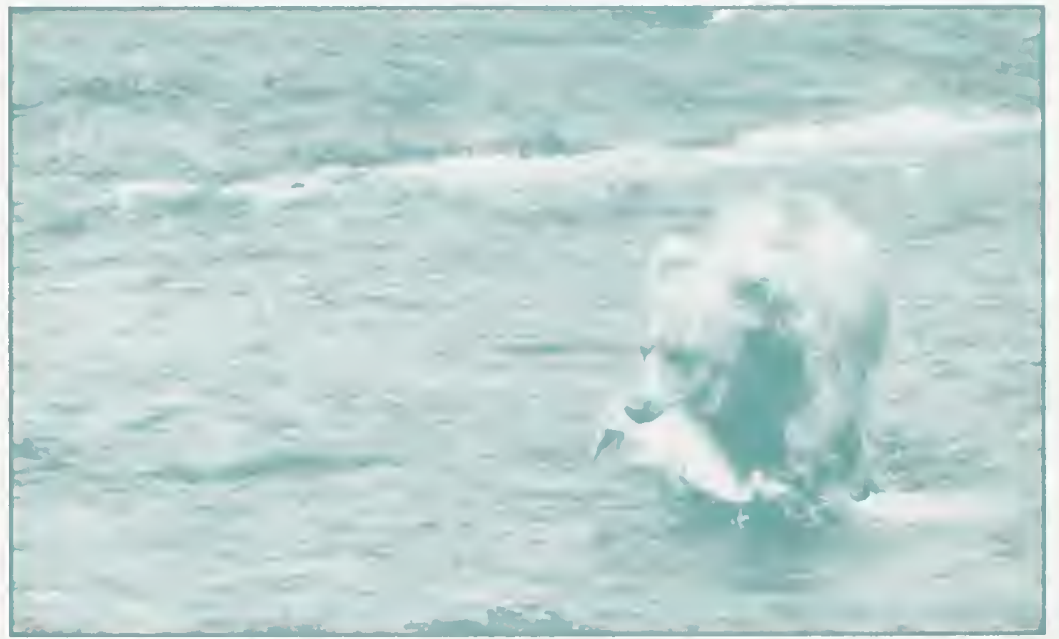




\section{The Project}

\section{"Give Moose a Brake" CoOperative Project SEWARD RANGER DISTRICT}

\section{The Benefits}

- moose habitat improvement on 173 acres

\section{The Work}

Moose/vehicle collisions on the Kenai Peninsula is the major mortality factor for moose. The objective of this project is to increase highway clearing to improve visibility and reduce the number of collisions, attract moose away from the highway by improving nearby habitat, and increase motorist awareness through the distribution of "Give Moose a Brake" window signs.
The Alaska Department of Transportation and Public Facilities provided additional clearing of their right-of-way, and the Alaska Fish and Game provided and assisted in distribution of the signs. The Seward Ranger District wildlife, timber, and fire departments coordinated vegetation projects designed to attract moose away from the highways.

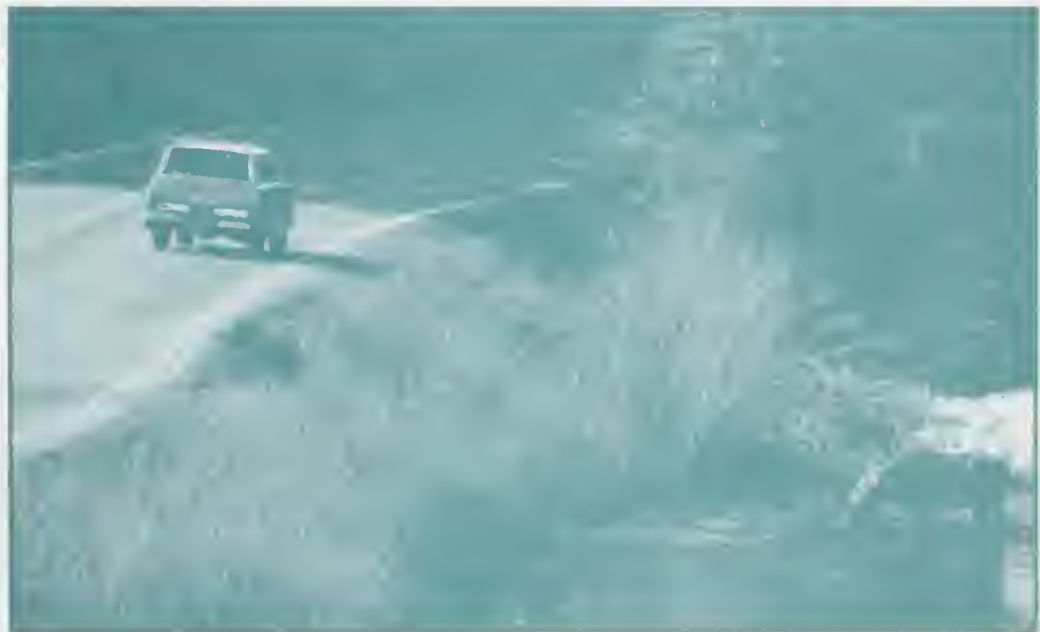




\section{The Project}

\section{Neotropical Bird Monitoring Project SEWARD RANGER DISTRICT}

\section{The Partners}

Their Contributions

U.S. Fish and Wildlife Service

(In-kind) $\$ 10,000$

Alaska Department of Fish and Game

(In-kind) $\$ 2,000$

Chugach National Forest $\$ 15,000$

\section{The Benefits}

- surveys of two breeding bird routes

\section{The Work}

In coordination with the Alaska Partners in Flight Working Group, the Seward Ranger District set up and conducted three breeding bird survey routes. The purpose of these surveys is to monitor population changes of birds which nest in Alaska and winter far to the south (tropics or near tropics). Agencies and groups in other states are assisting with this program using a variety of survey techniques. Seward's program is part of this state and national effort.

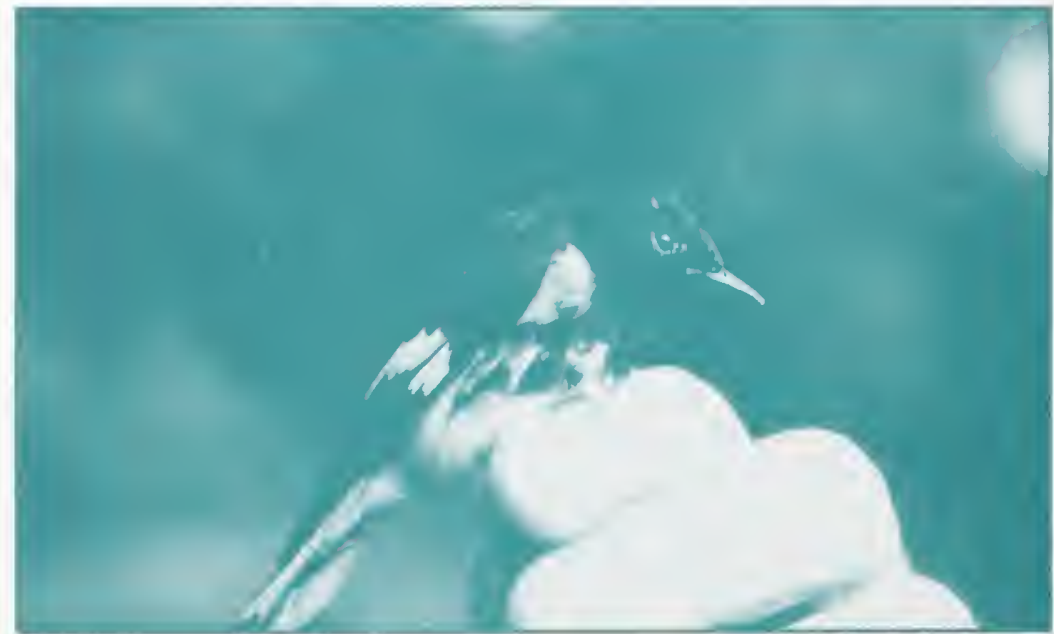




\section{The Project}

\section{Audubon Christmas Bird SuRvey \\ SEWARD RANGER DISTRICT}

\section{The Partners}

Their Contributions

Audubon Bird Club of Anchorage (In-kind) $\$ 3,000$

Seward Phoenix Log (Seward Newspaper) (In-kind) $\$ 200$ Chugach National Forest $\$ 440$

\section{The Benefits}

- conduct annual bird count

- news articles advertising and reporting on the event

\section{The Work}

Personnel from the Seward Ranger District assisted the Anchorage Chapter of the Audubon Bird Club conduct the annual Christmas bird count. Birders from throughout the country cover established areas each year. Results from these counts are used to determine general population trends and to educate the public. The local paper covered the eventadvertising and then reporting results.

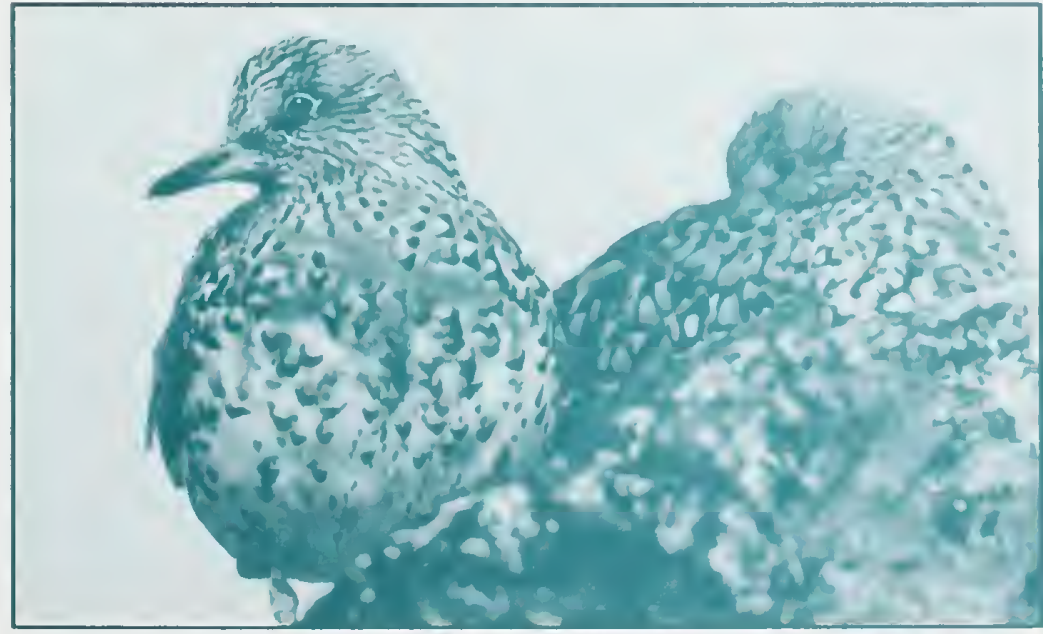




\section{The Project \\ KaChemaK Bay Shorebird Festival SEWARD RANGER DISTRICT}

The Partners

Their Contributions

Homer Chamber of Commerce .....................................................(In-kind) \$5,000

U.S. Fish and Wildlife Service...........................................................................\$5,000

Chugach National Forest .............................................................................................\$500

\section{The Benefits}

- more than 5,000 birders and interested people participated in weekend festival

\section{The Work}

Homer put on its first annual shorebird festival to celebrate the spring migration arrival of thousands of birds along the Kachemak Bay. All the local schools and many businesses

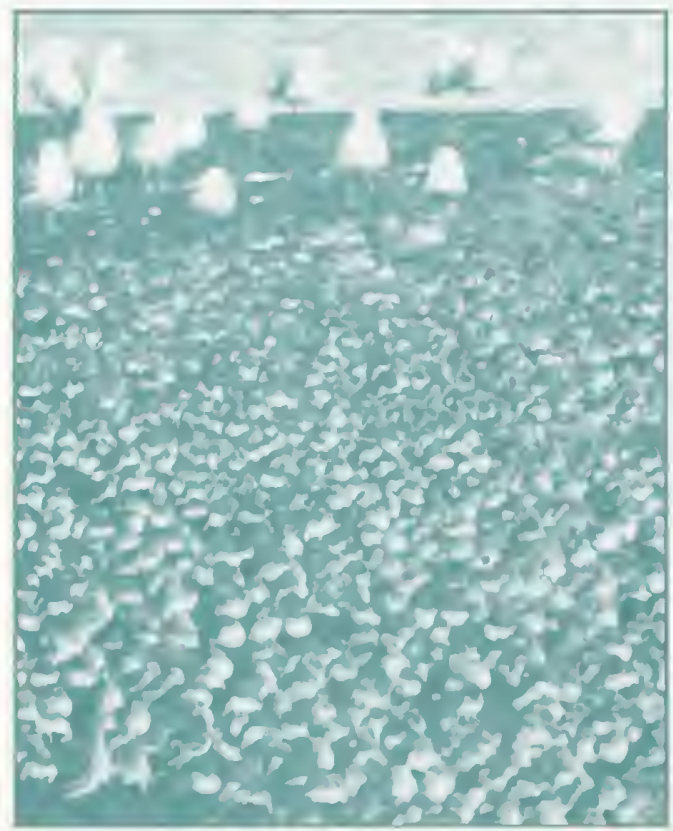

participated. Over 5,000 people were involved with the various programs. These included: field trips, identification workshops, plays, arts and crafts, education displays, and more. 


\section{The Project}

Prince William Sound Mountain Goat Survey CORDOVA RANGER DISTRICT

\section{The Partners}

Their Contributions

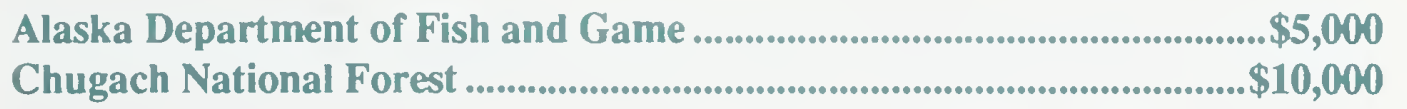

The Benefits

- population monitoring and subsistence management

$\cdot 110,000$ acres surveyed in 1993

\section{The Work}

In 1993, The Alaska Department of Fish and Game, and Cordova Ranger District surveyed approximately 110,000 acres of mountain goat range in the coastal mountains of Prince William Sound using small fixed-wing planes. This cooperative venture, which also includes Glacier Ranger District as a partner, provides vital information on population trends of goats to help set harvest goals that provide for customary and traditional subsistence harvest, as well as sport hunting. Results from 1993 surveys indicate a stable to increasing population in Prince William Sound. These surveys are necessary and aid in addressing future management opportunities as resource development activities increase within Prince William Sound and the Copper River Delta.

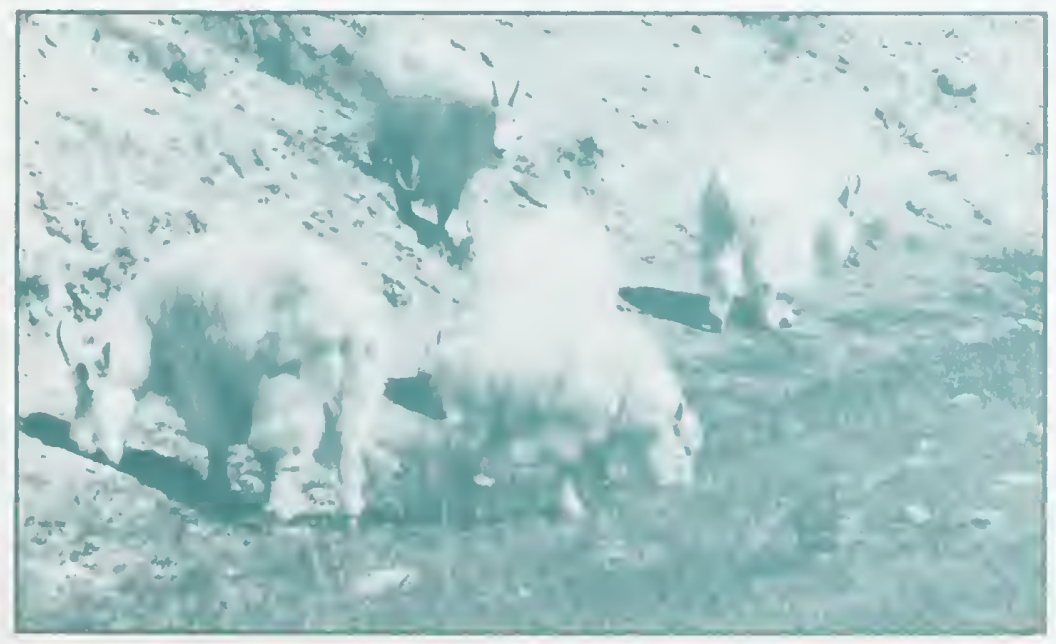

Mountain goats graze on alpine plants on the Chugach National Forest. 


\section{The Project}

\section{Copper River Delta Moose Habitat Study COPPER RIVER DELTA INSTITUTE}

\section{The Partners}

Their Contributions

Copper River Delta Institute, Pacific Northwest Research Station ......\$63,000

University of Idaho ......................................................................................\$7,000

Chugach National Forest ....................................................................\$20,000

\section{The Benefits}

- habitat improvement planning and monitoring

\section{The Work}

The Copper River Delta Institute is cooperating with the Chugach National Forest and the University of Idaho in assessing the important habitats used by moose on the Copper River Delta. This ongoing project will help determine the condition and trend of habitats, and moose populations on the delta.

The Copper River Delta Institute and university researchers have assumed a lead role in the quantitative monitoring of the 1990 and 1991 trial moose habitat improvements on the delta. Here, 200 acres of willow-alder stands were cut with a hydro-axe to test the feasibility of the technique and vegetative and moose response to treatment. By observing habituated radio-collared moose, both control and enhanced areas are being evaluated for diet composition, forage quality, quantity, . nutritional constraints, and the rate of plant succession.

In addition, the institute has been evaluating the historical changes in moose habitat on the delta by comparing aerial photos from 1959 and 1986. 


\section{The Project}

\section{SitKa BlaCk-TaIled DeER SuRVey CORDOVA RANGER DISTRICT}

Alaska Department of Fish and Game .........................................................\$\$ \$8,000

Chugach National Forest ...................................................................................\$2,000

\section{The Benefits}

- obtaining population information on Sitka black-tailed deer in Prince William Sound

\section{The Work}

The Cordova Ranger District is cooperating with the Alaska Department of Fish and Game (ADF\&G) in obtaining population information for Sitka black-tailed deer on the islands of Prince William Sound. Surveys consist of pellet group transects and vegetation descriptions following the Forest Service plant association system. Winter snow data were collected from various locations on Montague Island. This project will aid ADF\&G in population management of Sitka black-tailed deer in Prince William Sound. Data collected from this study will be a vital tool to help identify future management opportunities on the national forest in the Prince William Sound. 


\section{The Project}

\section{Dusky Canada Goose Nest Plot Surveys CORDOVA RANGER DISTRICT}

The Partners

Chugach National Forest

U.S. Fish and Wildlife Service

Alaska Department of Fish and Game

The Benefits
Their Contributions

$\$ 20,150$

.In-kind

In-kind

\section{The Work}

The Cordova District initiated a ground-based survey in 1993 to compare breeding pair densities from U.S. Fish and Wildlife Service aerial surveys with nest densities observed in the ground. A second objective is the description of plant to community types associated with observed nests. Random plots from four regions of the west Copper River Delta were sampled in 1993. The regions were based on breeding pair density data provided by the USF\&WS. This information will aid managers in identification of goose habitat capability and limiting factors and will allow for the analysis of goose nesting success within different plant community types.

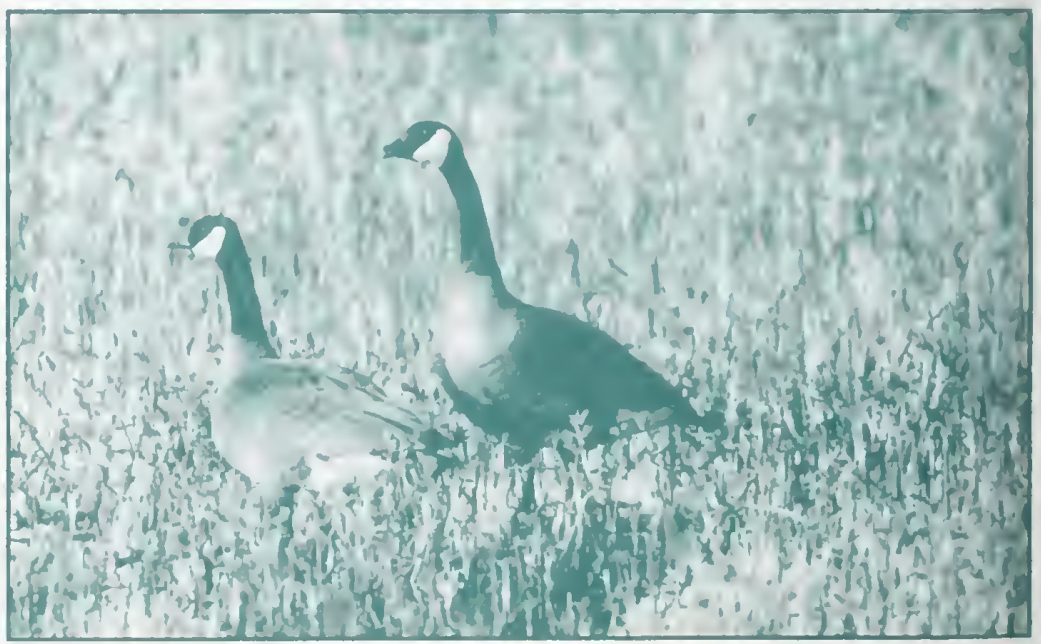




\section{The Project}

\section{BERING LAKE Trumpeter SWAN STUdy COPPER RIVER DELTA INSTITUTE}

Copper River Delta Institute.

\section{The Benefits}

- habitat planning and population assessment

\section{The Work}

The Copper River Delta supports the nation's largest breeding population of trumpeter swans on federal lands. More than $4 \%$ of the world's trumpeter swans nest on the Copper River Delta. Bering Lake, at the eastern reaches of the delta, aitracts up to 800 trumpeter swans staging in spring and fall and supports a summer population of up to 100 birds.

This critical swan staging and summering area may be impacted by future development. The 1982 Chugach Natives, Inc. Settlement Agreement guarantees a road easement to access Native inholdings north of Bering Lake. The two alternatives for the proposed access road border Bering Lake.

Cooperating with the U.S. Fish and Wildlife
Service, the Copper River Delta Institute neckbanded almost 100 trumpeter swans at Bering and Martin Lakes during July 1991 and July 1992. In September 1992, the Copper River Delta Institute and The University of Minnesota began a cooperative study to provide data on swan ecology at Bering Lake during spring and fall.

In 1993, swan habitat use investigation continued in cooperation with Copper River Delta Institute, and the University of Minnesota. Information collected during this study will be critical in mitigating resource impacts if an access road to native inholdings is developed. 


\section{The Project}

EVAluATION OF BODY CONDITION INDICES FOR ASSESSING

Nutritional Status OF MOOSE

ON THE COPPER RIVER DELTA

COPPER RIVER DELTA INSTITUTE

Copper River Delta Institute ....................................................................\$4,000

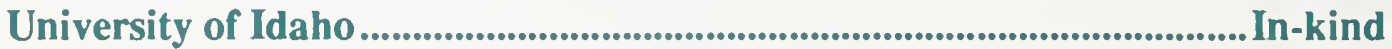

Alaska Department of Fish and Game .......................................................... In-kind

\section{The Benefits}

- improved assessment of moose population's nutritional status

\section{The Work}

The Copper River Delta Institute and the Alaska Department of Fish and Game's Moose Research Center have been cooperatively testing a new method to evaluate animal condition. In many management applications, animal condition can indicate a population's proximity to carrying capacity. Condition indices based on procedures such as bioelectrical impedance analysis, titrated water dilution, and whole body grinding exhibit a strong relationship with nutritional status. The Institute and the Moose Research Center are using bioelectrical impedance analysis and ultrasound on captive moose to determine body composition. This technique may enable biologists to more accurately assess the condition of wildlife populations at a lower cost. 


\section{The Project}

\section{POPUlation DyNAMICS OF GRAY WOLVES ON THE COPPER RIVER DELTA \\ COPPER RIVER DELTA INSTITUTE}

\section{The Partners}

Their Contributions

Copper River Delta Institute $\$ 25,000$

University of Idaho In-kind

Chugach National Forest In-kind

\section{The Benefits}

- population assessment of gray wolves

\section{The Work}

The Copper River Delta Institute is undertaking the first study of the Copper River Delta's wolf population. In 1987-88, the wolf population on the delta was estimated to be 20-34 individuals. Wolf numbers likely fluctuate in response to prey availabiltiy and human harvest.

In February 1992, six wolves were radiocollared as part of the first phase of a wolf population dynamics study. In 1993, an additional seven wolves were collared. Wolves are being radio-located at least once a week from fixed-wing aircraft to determine pack territory boundaries, survival, and dispersal. Mortality causes (natural and human-related) are also determined from radio-collared wolves and by cooperation with local hunters and trappers. By monitoring changes in population size, recruitment, survival, mortality, and dispersal during several years, a good understanding of wolf population dynamics on the delta will result. 


\section{The Project}

\section{Physiology OF MigRation In WeStern SANDPIPERS COPPER RIVER DELTA INSTITUTE}

Copper River Delta Institute $\$ 1,500$

University of Washington $\$ 15,000$

BP Exploration (Alaska Inc.) In-kind Accord Environmental In-kind

\section{The Benefits}

- information about the ecology of western sandpiper migration

\section{The Work}

Western sandpipers undertake a long migration every year to and from their breeding grounds in northwest Alaska. Although the distance traveled is the same, aspects of physiology and behavior may differ between spring and fall migrations.

The Copper River Delta Institute is working in cooperation with the University of Washington to study seasonal differences in western sandpiper hormone levels. Previous studies have shown that hormones known to regulate fat deposition and migratory behavior in other long distance migrants are present in blood plasma at high levels during spring migration, but low levels during fall migration. Because hormone levels and behavior may differ at different locations, the sandpipers are analyzed for seasonal differances at migration stop-overs at Bodega Bay, California; Gray's Harbor, Washington; and the Copper River Delta. Observations of foraging behavior will be used to assess the intensity and duration of foraging during spring and fall migrations. This project will be completed in 1994. 


\section{The Project}

\section{MIGRATORY SHOREbIRd Staging ON THE COPPER RIVER DELTA COPPER RIVER DELTA INSTITUTE}

Copper River Delta Institute $\$ 30,000$

National Fish and Wildlife Foundation $\$ 15,000$

Exxon Company, USA $\$ 15,000$

Chugach National Forest . (In-kind) $\$ 2,500$

\section{The Benefits}

- shorebird habitat evaluation and population assessment

\section{The Work}

The 700,000 acre Copper River Delta supports the largest migration and staging area for shorebirds in the Western Hemisphere. A total of 23 species of shorebirds regularly use the delta on their northward migration. The majority of the world's western sandpipers and Pacific dunlins feed on the vast mud flats of the delta each spring before flying on to their nesting grounds in western Alaska.

Despite the delta's international significance as a shorebird resource, little information exists on the numbers of shorebirds and their distribution and concentration areas.
Beginning in 1991, the Copper River Delta Institute initiated low-altitude aerial shoreline surveys to determine the timing of migration, shorebird numbers, and distribution. Ground transect surveys are being conducted at selected sites to determine species composition. Combined with a radio-telemetry study on western sandpipers, the role of the Copper River Delta relative to Pacific coast and Western Hemisphere migration systems is being assessed. Data collection will continue for the next three years. 


\section{The Project}

\section{CopPer River Delta Aerial MoOSE Survey CORDOVA RANGER DISTRICT}

Alaska Department of Fish and Game .........................................................\$\$,000

Chugach National Forest ........................................................................................\$1,000

\section{The Benefits}

- obtaining populations information on moose on the Copper River Delta - assessing habitat enhancement projects

\section{The Work}

The Cordova District participates with the Alaska Department of Fish and Game in obtaining population trend information for moose on the Copper River Delta. Personnel from both agencies fly transects over several sampling units across the delta. This project aids $A D F \& G$ in population management of moose and will help the Forest Service to evaluate the effectiveness of habitat enhancement projects completed on the delta. 


\section{The Project}

\section{COPPER RIVER WATERFOWL SURVEYS \\ CORDOVA RANGER DISTRICT}

\section{The Partners}

Their Contributions

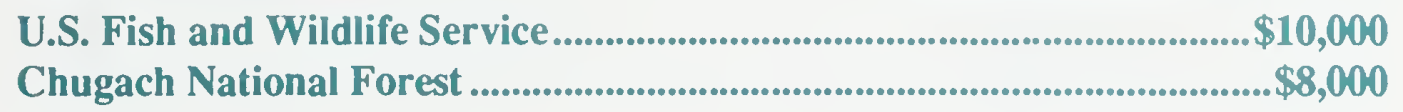

The Benefits

- obtaining population information on waterfowl on the Copper River Delta

\section{The Work}

The vast wetlands of the Copper River Delta support large numbers of nesting waterfowl. Nearly $100 \%$ of the world's population of dusky Canada geese and 5\% of the world's population of trumpeter swans, nest on the Copper River Delta. In addition, the delta supports large numbers of nesting ducks including mallards, wigeon, pintails, ringnecked ducks, green-winged teal, northern shovelers, and gadwalls. Waterfowl populations are surveyed annually from the air by the U.S. Fish and Wildlife Service (USFWS).
Through the surveys population counts and indices are monitored. The USF\&WS and Cordova Ranger District conduct counts of trumpeter swans using aerial surveys and obtain information on active nests in the spring and cygnet production in the fall. Dusky Canada goose population indicies are monitored for number of pairs, singles and flocks. The Cordova District provides coordination, funding and logistical support for these surveys. Data collected from the surveys are instrumental in developing the District's habitat enhancement plans. 


\section{The Project}

\section{DISTRICT INVENTORY AND MONITORING GlaCIER RANGer DisTRICT}

\section{The Partners}

Their Contributions

Cordova Ranger District $. \$ 5,000$

Glacier Ranger District. $\$ 3,000$

\section{The Benefits}

- 5,000 acres Sitka black-tailed deer habitat surveyed

- 5,000 acres mountain goat habitat surveyed

- improved cooperative management of the Prince William Sound ecosystem

\section{The Work}

The goal of the Glacier Ranger District Wildlife inventory and monitoring program is to develop a historical record of species distribution and abundance, systems attributes and habitat diversity and distribution for the ecosystems of Southcentral Alaska through long-term monitoring and inventory. Towards this end, the district had undertaken several cooperative projects including neotropical migratory bird monitoring and winter moose population monitoring both of which are discussed separately. Additionally, the district contributed funds to Prince William Sound mountain goat monitoring, as well as provided assistance for Sitka black-tailed deer surveys conducted on Montague and Hinchinbrook Islands. 


\section{The Project}

\section{NEOTROPICAL MigRATORY BIRD MONITORING GLACIER RANGER DISTRICT}

\section{The Benefits}

- approximately 1,000 acres of avian habitat inventoried

- 723 individuals of 22 species captured and banded

- participation in network of statewide monitoring efforts

- improved management of migratory landbird habitat

\section{The Work}

In an effort to identify trends in populations of migratory land birds, the district established a constant effort mist net station which operated during both spring and fall migration as well as during the breeding season. In over 1,000 net hours between April 23 and September, 23, 1993, district and U.S. Fish and Wildlife personnel captured and banded 723 birds of 22 differenct species. Spring netting was done in low willow/poplar habitat and MAPS and fall netting were done in open, mixed spruce/alderpoplar habitat. In addition, one point count transect was established. Together, these efforts, both in Portage Valley, sampled approximately 1,000 acres of habitat.

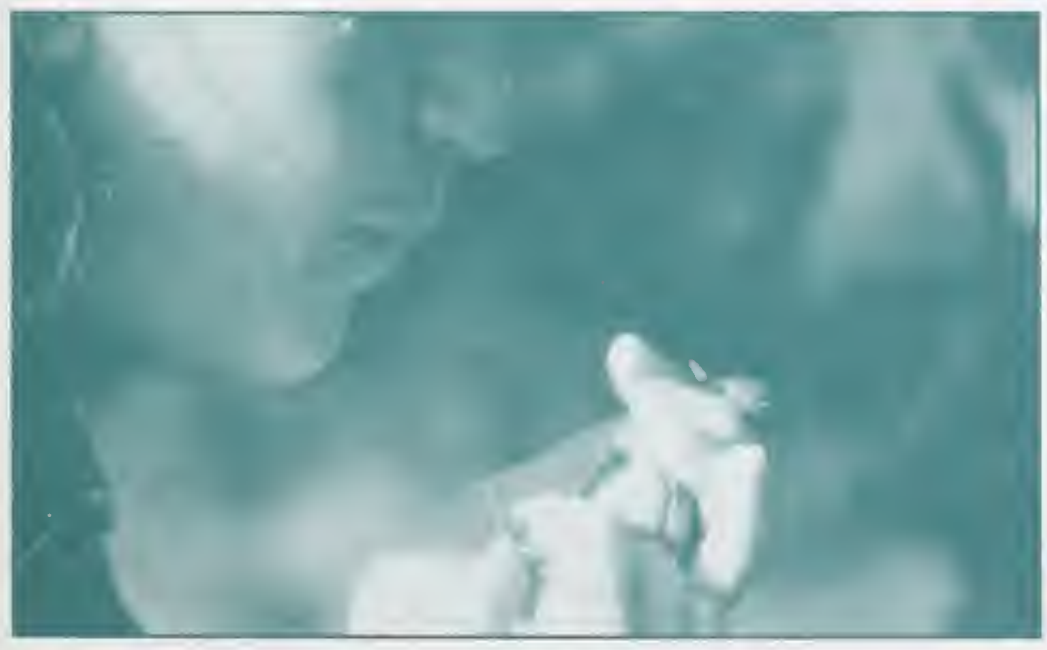

Kristen Bartecchi estimating body fat and sexing a banded orange-crowned warbler. This and 21 other species were banded throughout spring and fall migration and breeding season in Portage Valley. 


\section{The Project}

\section{MoOSE WinTER ECOLOGY \\ GLACIER RANGER DISTRICT}

\section{The Partners}

Their Contributions

Exxon Company, USA $\$ 15,000$

Alaska Department of Fish and Game $\$ 1,000$

Glacier Ranger District $\$ 7,000$

\section{The Benefits}

- improved interagency management of moose

- approximately $\mathbf{4 0 , 0 0 0}$ acres of moose habitat inventoried

\section{The Work}

In cooperation with $A D F G \& G$ and Exxon Co., USA, 40,000 acres of moose habitat was inventoried in Twentymile, Portage, Placer, and Bear Valleys. Habitat quality in this area is very good with a present population of over

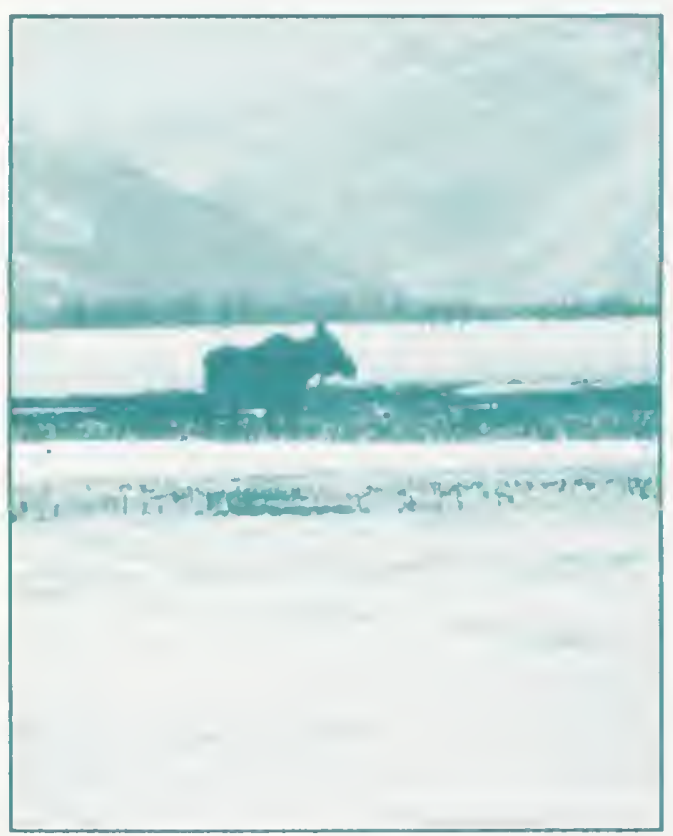

300 moose. The goal of this project is to determine the quantity and quality of moose winter range in Portage Flats Wildlife Habitat Management Area. Both the Forest Service and the ADF\& $G$ would like to maintain a healthy and highly visible herd in the Portage Flats Management Area. Under this project, winter herd movements are being monitored, winter range identified and its components described.

Cow moose feeding in the Twenty-Mile Valley and silhouetted against the magnificent Chugach Mountains. 


\section{The Project}

\section{Turnagain ARM Marine Mammal Stranding Network GlaCier RANGer DisTrict}

\section{The Partners}

National Marine Fisheries Service

Glacier Ranger District
Their Contributions

In-kind $\$ 2,000$

\section{The Benefits}

- improved interagency management of marine mammals in Turnagain Arm

- increased public awareness of the dynamics of marine ecosystems

\section{The Work}

In early 1993, the Chugach National Forest and the National Marine Fisheries Service (NMFS) signed a letter of agreement in an effort to provide for a coordinated and safe response to marine mammal strandings in Turnagain Arm. Under this agreement, the district responded to two stranding events this year. On July 6 , ten beluga whales were stranded south of Hope, and on August 24,

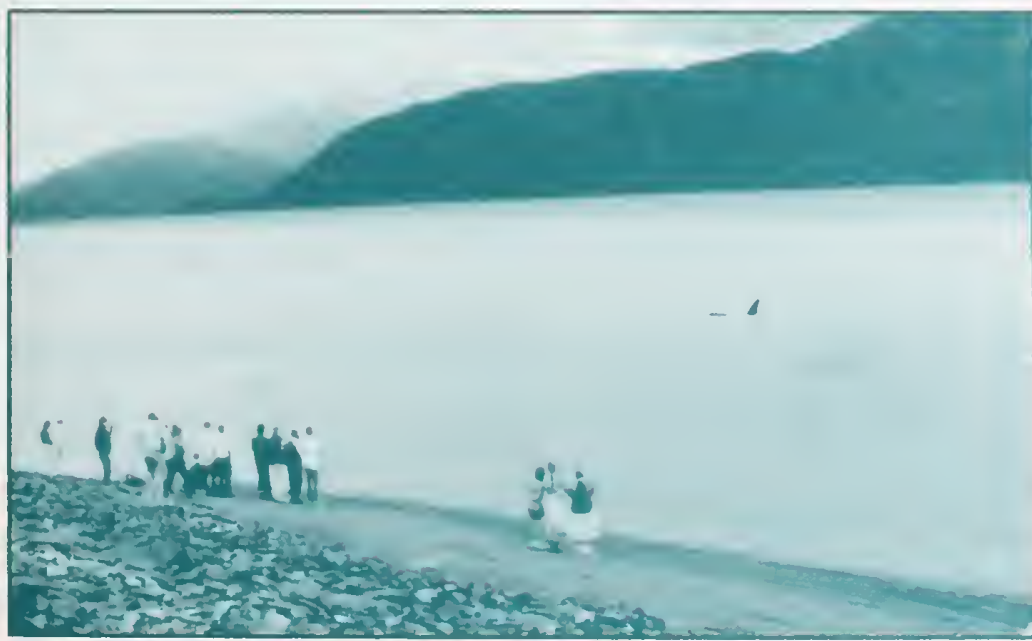

five Orcas were stranded just east of Bird Point. Due to high visibility and easy access, the August stranding attracted approximately 200 onlookers and included the involvement of the Forest Service, NMFS, the Alaska State Troopers, the Alaska Railroad, the Air National Guard, and citizen volunteers. In these events, the district provides initial response, assesses the situation and recommends further response actions. 



\section{FISHERIES}




\title{
The Project
}

\section{TWENTYMile River \& PlaCER River \\ SPORTFISHERIES MANAGEMENT PLAN \\ GlaCier RANGer DiSTRICT}

\section{The Partners}

Their Contributions

\author{
Alaska Department of Fish and Game .............................................................\$200 \\ Chugach National Forest ...........................................................................\$5,000
}

\section{The Benefits}

- fisheries management strategy and habitat improvement planning

\section{The Work}

Both the Placer and Twentymile River systems support anadromous sportfish and offer unroaded recreation opportunities in close proximity to metropolitan Anchorage. A dipnet fishery for (eulachon) is popular activity on the Twentymile River.

With the increasing demand for alternative sportfishing opportunities and concems for wild salmon stocks and resource development, planning efforts are needed to develop long- term habitat and recreation management strategies. Assessment of the fisheries resources of these systems will be of significant value to the Glacier Ranger District during future revision of the Chugach National Forest plan.

Cooperative sportfish planning was initiated in 1991. This planning effort will continue in 1994 with the development of a draft strategy plan for these river systems.

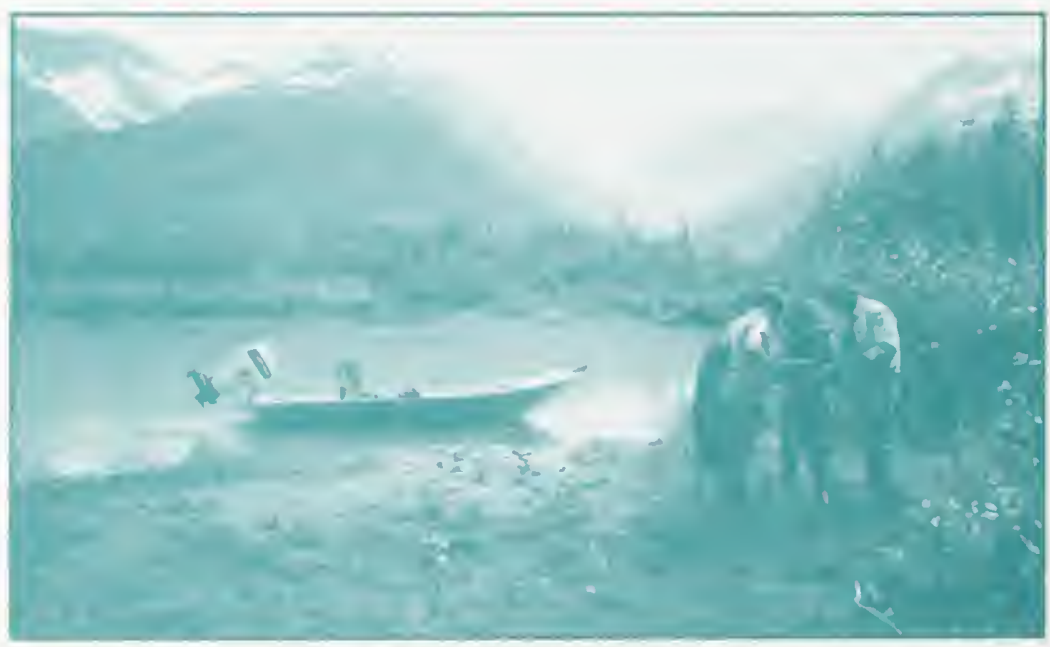

Forest Service personnel conduct a salmon escapement count and creel census on Twentymile River. 


\section{The Project}

\section{KenaI SMaLL LAKES RESIDENT \\ SPORTFISH DEVELOPMENT \\ SEWARD RANGER DISTRICT}

\section{The Partners}

Their Contributions

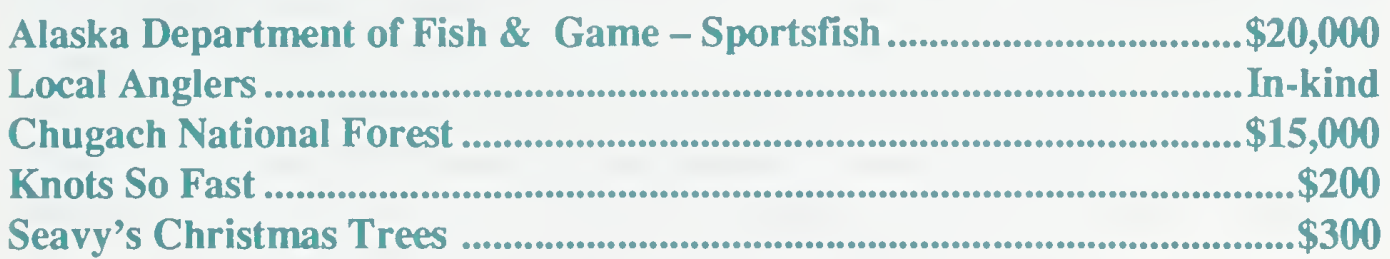

\section{The Benefits}

- 18 lake habitat improvement (fish attraction) structures

- stocked 334,000 rainbow trout in five lakes

- add two lakes to ADF\&G 1993-1996 stocking plan

\section{The Work}

The Kenai Small Lakes program has been an ongoing project for over ten years on the Seward Ranger District. The District Fisheries staff works cooperatively with $A D F \& G$ to monitor fisheries and habitat in over 20 lakes, stocks eight lakes with rainbow trout, identifies barren lakes which can support a sportfishery, and since 1991, has conducted lake habitat improvements.

In recent years, local partners have played an important role in carrying out this program.

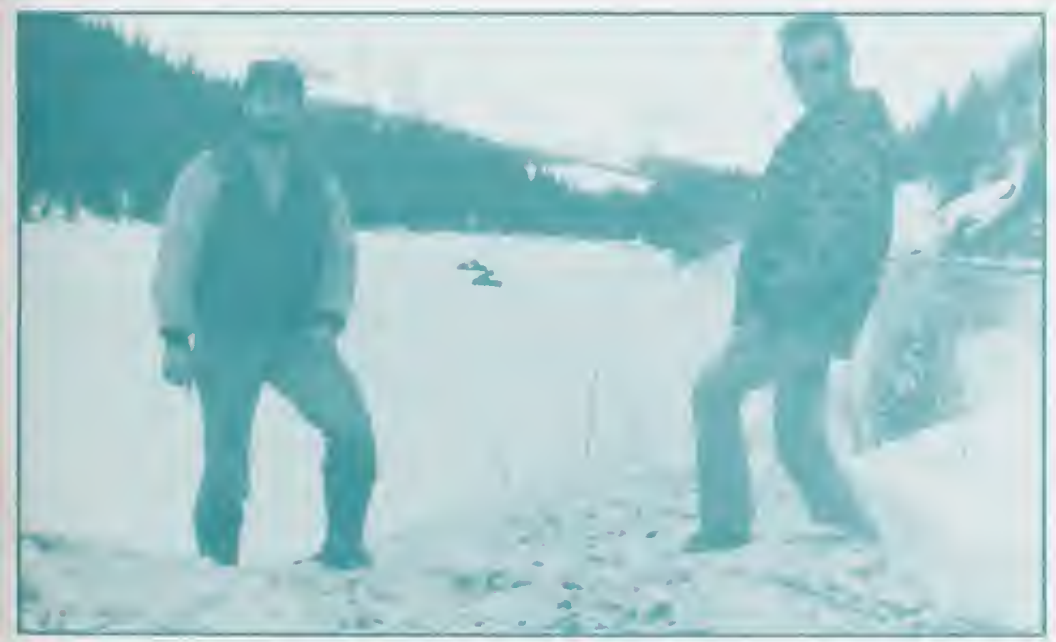

Here is how partners helped in 1993. Discarded Christmas trees received from the public were used to construct 18 lake habitat improvement (fish attraction) structures which were placed in Jerome and Summit Lakes. Structures were placed offshore of popular bank fishing areas with the intent of attracting fish and improving fishing opportunities for shore anglers. Seward area residents provided 75 trees and Christmas tree vendors in Seward donated over 60 trees which they did not sell. Assisting the district fisheries staff with backpack stocking of five lakes were several local anglers along with employees from other resource staffs on the district. Local anglers and the Seward Boy Scouts will be assisting the Forest Service during the coming years in constructing access trails to two district lakes that were added to the ADF\&G stocking plan in 1993.

Seward Ranger District Fisheries Technicians Jay Perlberg and Larry Winter overlook fish attraction structures placed on the ice of Jerome Lake. 


\title{
The Project
}

\section{RESURRECTION CREEK FISHERIES HABITAT RESTORATION SEWARD RANGER DISTRICT}

\section{The Partners}

\section{Their Contributions}

\begin{abstract}
Alaska Dept. of Fish \& Game - Habitat Restoration Division $\$ 1,000$

Alaska Dept. of Fish \& Game - Commercial Fisheries Division $\$ 500$

Chugach National Forest $\$ 55,000$
\end{abstract}

\section{The Benefits}

- 20 instream habitat enhancement structures

- 10 miles basin level habitat survey

\section{The Work}

A long history of placer mining in the Resurrection Creek drainage has reduced fisheries habitat through channelization, elimination of side channels, removal of instream boulders, and removal of riparian vegetation. This long term fisheries restoration project targets rehabilitating fisheries habitat in stream reaches impacted by mining activity, using a mix of instream structures, off channel rearing enhancement and riparian zone revegetation. During 1993, the Seward Ranger District, in cooperation with Alaska Department of Fish and Game, conducted the 4th year of fisheries and habitat evaluation on Resurrection Creek, and the 2nd year of instream fisheries habitat restoration, constructing 20 instream structures provements on the Pearson Mining Claim, which will be done in FY 94 by volunteers from Raleigh International.

Partners involvement in the project included $A D F \& G$ paying $25 \%$ of equipment operation costs while Fritz Kraus of ADF\&G - Commercial Fisheries Division, provided valuable technical assistance in instream structure design. Forest Service funding for the project came from the district fisheries program, and the Forest Watershed and Ecosystem Management programs.

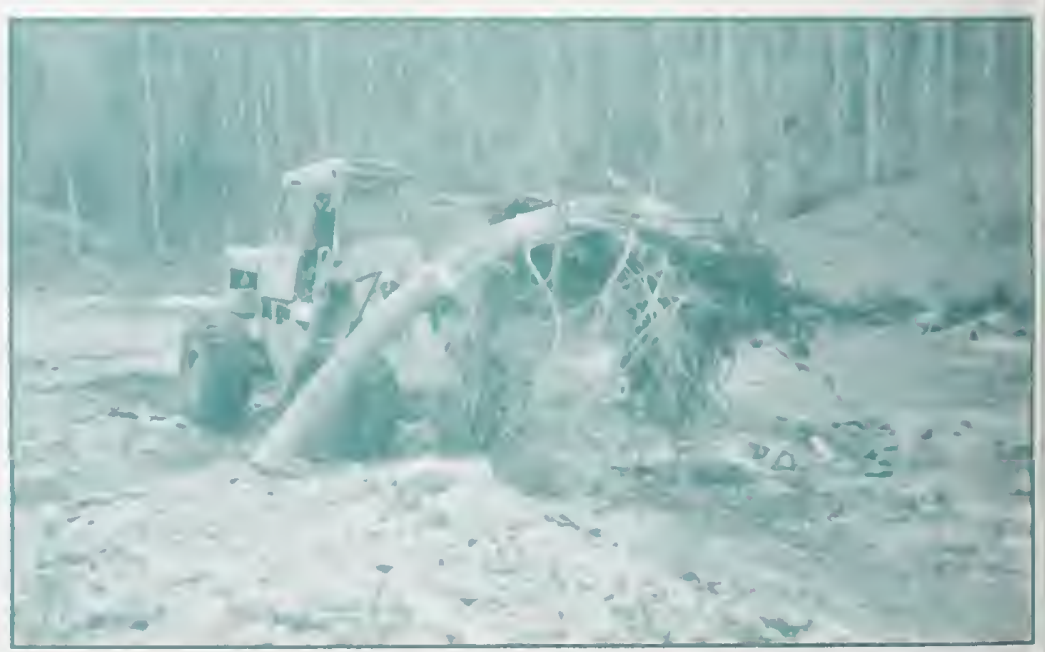


The Project

\section{RESIDENT LAKE CUTTHROAT STUDY CORdova Ranger District}

Their Contributions
Alaska Department of Fish and Game
$\$ 4,000$
Chugach National Forest
$\$ 8,000$

\section{The Benefits}

- collected scale samples for age, growth, and life history analysis

- obtained species composition of a lake system modified by steeppass

- obtained sportfishing catch-per-unit effort indices for steeppass-modified and closed system

\section{The Work}

Prince William Sound and the Copper River

Delta have numerous closed lake systems that support resident populations of cutthroat trout. The fish in these lakes are typically under ten inches and are often stunted. These lakes have traditionally been popular with anglers

because the lake cutthroat are relatively easy to catch and large numbers can be caught in a short period of time. Some of these closed lake systems have been opened with steeppasses to increase habitat and enhance runs of coho, pink, and sockeye salmon.

Recent declines in cutthroat trout throughout their range has raised concerns of overfish-

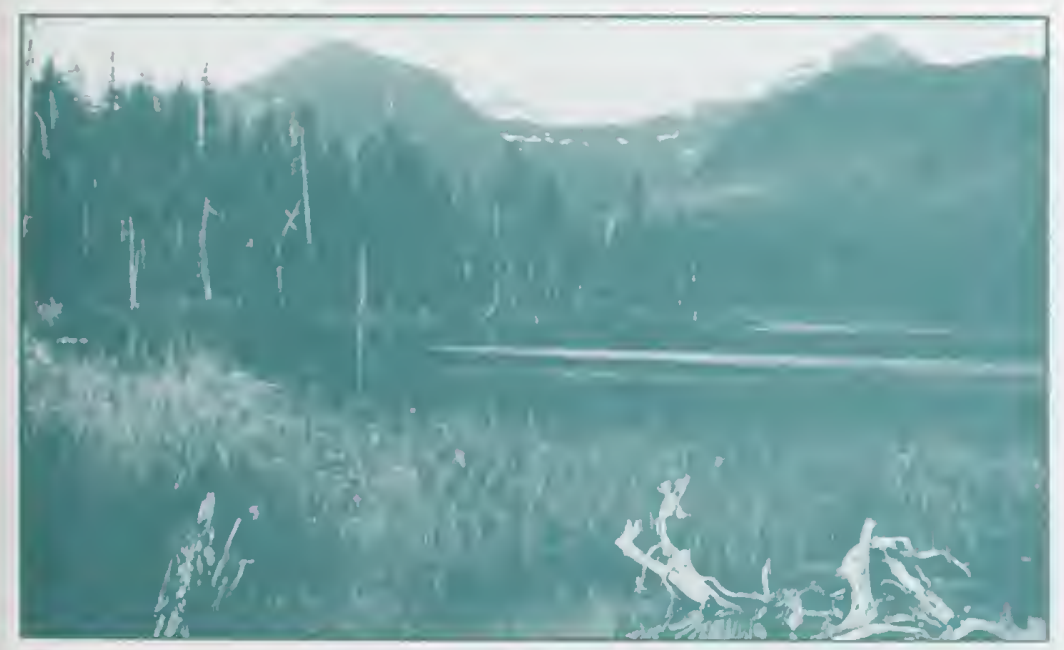

ing in some of these lakes and of the effects of steeppass-introduced salmonids. The effects of overfishing and steeppasses may be even more pronounced in many of these lakes where, typically, the growing season is short, food production is low, and the resident cutthroat are stunted. Increased management for these lake cutthroat trout is anticipated but little baseline information concerning these stocks is available.

In 1993, the Cordova Ranger District initiated a study to evaluate production in lake systems supporting stocks of resident cutthroat trout and attempted to quantify the effects of steepasses. Sampling was conducted in three lake systems; two of these were closed systems and the third had been opened via a steeppass. Fork lengths, weights, and scale samples were taken for comparison of growth and age parameters between the systems. Scale analysis should be completed by spring 1994. Food availability and production studies will be carried out in 1994. Population estimates, survival, and genetic analysis is also needed but will depend upon future funding.

Pipeline Lakes, on the Copper River Delta, is one of the survey areas for the District's cutthroat trout lake study. 


\title{
The Project
}

\section{MILE 18 CUTTHROAT-DOLLY VARDEN STUDY \\ CORDOVA RANGER DISTRICT}

\section{The Partners}

Their Contributions

\begin{abstract}
Alaska Department of Fish and Game
Chugach National Forest

\section{The Benefits}

- collected baseline data on age and lengths, identified and characterized delta runs

- collected total enumerations and conducted spawning surveys

- collected cutthroat scales for analysis of age, survival, and life histories
\end{abstract}

$\$ 10,000$ $\$ 121,000$

\section{The Work}

Historically, the Copper River Delta and southeastern Prince William Sound have supported strong and stable populations of anadromous cutthroat trout. While very little information exists on current population levels, decreases in numbers have been reported and habitat degradation due to development, timber harvest, and oil spill effects along with increased sportfishing pressures have resulted in concern for Forest stocks.

The Cordova Ranger District began working closely with ADF\&G Sportfish in 1991 to inventory cutthroat trout habitat and assess the population status. In 1993, a three year project was implemented on the Mile 18 stream system, east of Cordova. A seventyfoot, full-capture weir was constructed to enumerate abundance and gather baseline information on sea-run cutthroat stocks. Stream-habitat analysis surveys are being carried out in the system in conjunction with the weir.
The Cordova Ranger District monitored cuthroat trout and Dolly Varden Char numbers during FY 1993.
The information gained will give us a better understanding of the capability of the Mile 18 system and provide direction in management and regulation of stocks. Identifying limiting factors will also contribute to developing models for predicting cutthroat productivity.

Preliminary results of this year's field work have shown numbers of emigrating cutthroat to be lower than expected and survival of spawners possibly lower than the literature suggests. In addition, a spring run of cutthroats was observed in addition to the fall run. Information on age and growth from scale sample analysis is presently being carried out and should be completed by the end of this year.

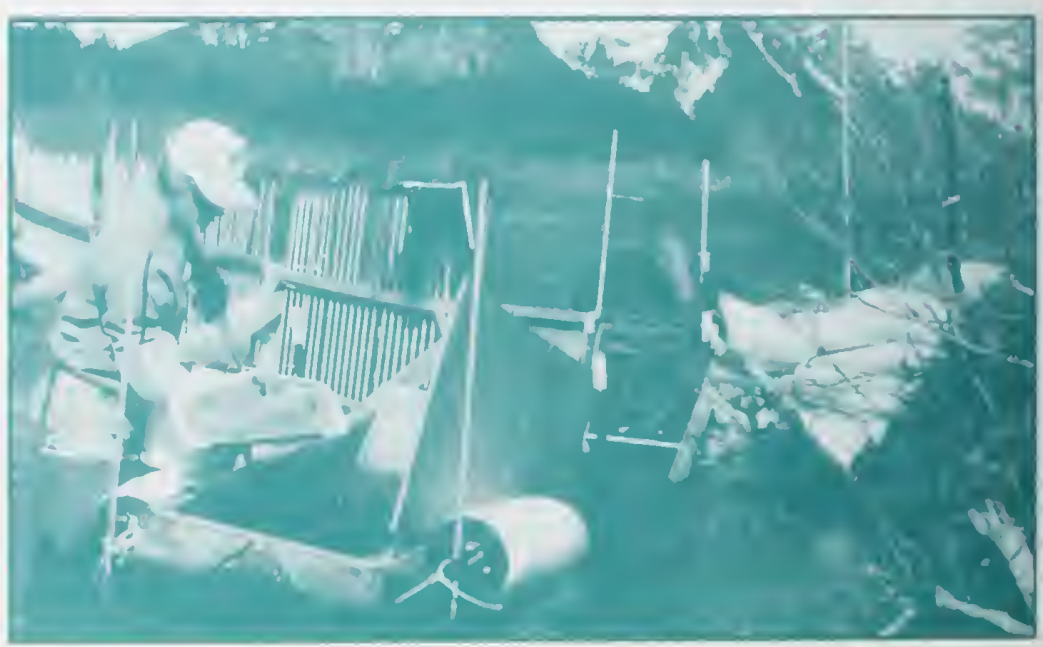




\section{FishWAY MAINTENANCE AND MONITORING CORdOVA RANGER DISTRICT}

\section{The Partners}

\section{Their Contributions}

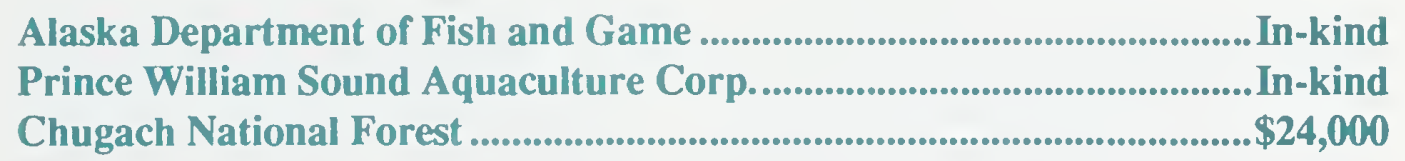

\section{The Benefits}

- all maintenance and reconstruction completed

- impedance counter performance evaluated, problems identified

- all other escapement counts completed

\section{The Work}

The reconstruction of the headwall at Boswell Bay was one of the major projects of the 1993 Cordova Ranger District fisheries program.

The project required a three-day trip for a fourperson crew to move supplies and equipment in, and then a five-day trip for an eight-person crew for the actual construction. The project ran smoothly and was finished well ahead of schedule. Post-project monitoring has shown that the headwall is holding up to high flows and performing as it should. The other steeppasses are all in good condition and required only routine maintenance.

The escapement at each steeppass was monitored closely, with three to five visits made to each steeppass during the spawning season. The data show that pink and coho runs

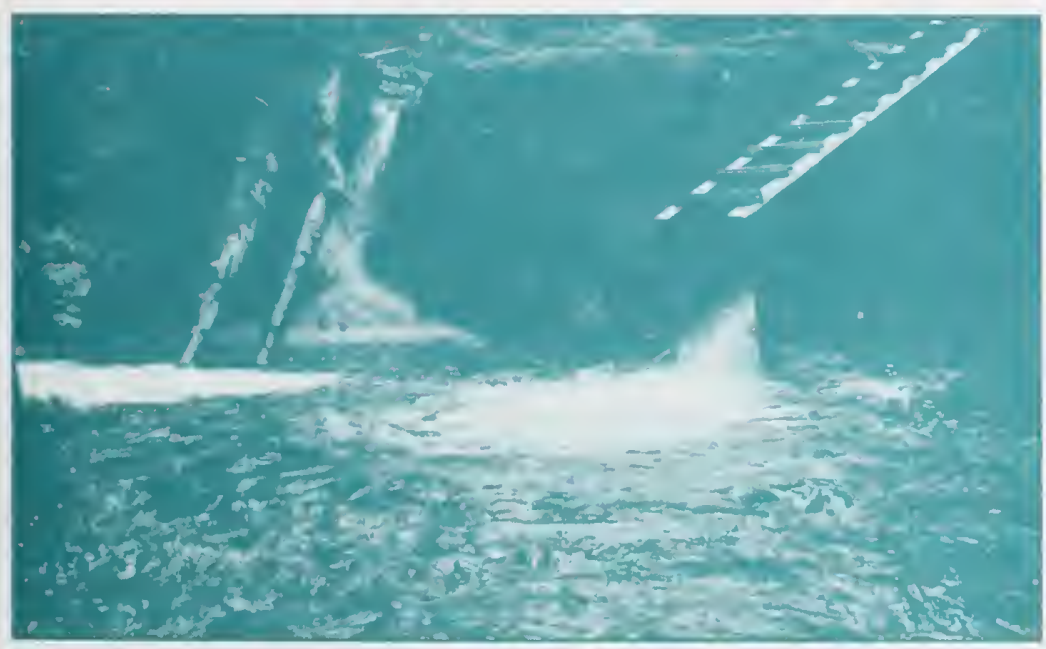

are doing well. However, we have been unable to assess the sockeye runs effectively since they move into the lakes to spawn, where they are difficult or impossible to see.

This year we purchased and installed an electric impedance counter to monitor sockeye runs. A district in Southeast Alaska has used counters successfully, but we were faced with technical problems. Because of the unusually dry weather this year, the streams were not flowing at normal levels and the flows were not high enough to fill the impedance tube. We found that the counter would count air bubbles, waves and other disturbances unless the tunnel was completely filled. Next year we hope to remedy the situation and obtain more accurate results.

Over the years, our monitoring has shown that the steeppasses are contributing to the local fisheries and helping to maintain the wild stocks of Prince William Sound. In the future, however, there will need to be major repairs, including additional work at Boswell Bay. We will need to dedicate a large amount of our time and effort to this work in the next few years to make sure that the steeppasses remain operable and the runs remain uninterrupted.

The Cordova Ranger District regularly monitored and maintained all fish structures on the District, such as the Olsen Bay steeppass. 


\title{
The Project
}

\section{Mile 18 CREEK BASIN WILd Habitat SuRVEY AND Coded Wire Tagging Project CORDOVA RANGER DISTRICT}

Their Contributions

\begin{abstract}
Alaska Department of Fish and Game ......................................................\$12,000
Chugach National Forest ............................................................................................\$18,000
\end{abstract}

\section{The Benefits}

- spawning area identified as limiting habitat factor; 566 pairs of successful spawners needed to fully seed habitat

- smolt production estimate using surveys and models is within $13 \%$ of actual production

- results validate survey and models as effective tools for predicting coho production - worked closely with ADF\&G on tagging program, $65 \%$ of out-migrating coho smolts were tagged

\section{The Work}

Mile 18 Creek is a good producer of coho salmon, cutthroat trout, and Dolly Varden char. It is also a popular creek for sportfishing, since it is close to Cordova. In 1992, there was relatively high fishing pressure early in the coho salmon season. The Alaska Department of Fish and Game feared that the coho escapement would be inadequate, and an emergency sportfishing closure was imposed.

This closure was controversial since it was not known how many spawners were needed for an adequate escapement, how many fish were produced in the system, and how many fish were being caught by the commercial fishery, which was not closed. Answers to these questions would reduce the uncertainties in the management of the sport and commercial fisheries.
The Cordova Ranger District fisheries crew operated a full-capture weir at the mouth of Mile 18 Creek from April 6 to July 17, 1993, with daily counts of all species migrating both upstream and downstream. A high percentage of the coho smolt were tagged (65\%) to ensure a good estimate of the catch by the commercial fleet. The Alaska Department of Fish \& Game provided tagging equipment and weir material, and will be responsible for the tag recovery.

The second part of the project was a basin wide habitat survey using the methods described by Hankin and Reeves (1988) and applying these data to coho production models by Reeves et al. (1989) and Murphy et al. (1990). These methods require considerably more effort than other survey methods since all of the habitat in the system is examined. 
These methods do, however, eliminate errors resulting from data extrapolation and give a statistical means for determining the accuracy of the data. A linear regression test showed that our crew was highly accurate and consistent. Their performance was comparable to, and actually exceeded, the results presented by Dolloff et al. (1993).

The habitat information was then used in the production models to predict the smolt production in the system. The predicted number $(25,689)$ was quite close to the actual number counted at the weir $(22,783)$. This gives us increased confidence that our methods are sound, and the models applicable to this area.

The models also indicate that spawning areas is the limiting factor in this system, unlike other systems in the area where the limiting factor is generally thought to be

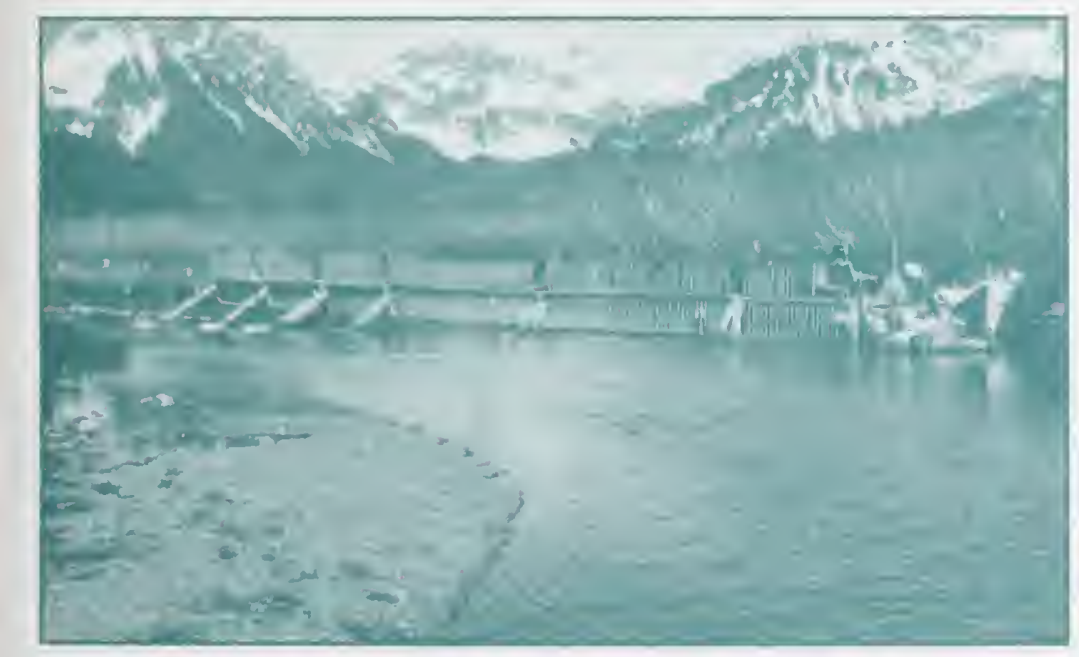

overwintering habitat. Estimates of the spawning area needed per pair varies considerable in the literature, however, the model by Reeves et al. (1989) indicates that there is spawning area for 566 pairs. The escapement would need to be higher depending upon the amount of predation and other factor.

This project will provide valuable information for the management of the fisheries by $A D F \& G$, and for habitat management by the Cordova Ranger District if it is determined that production needs to be increased in the system. This effort has also shown that the survey methods and models can be good predictors of coho production. We will continue to operate the weir to assess the natural population fluctuations and see whether the estimates of the model continue to be reasonably accurate.

The Cordova Ranger District, with $A D F \& G$, installed a full-capture weir on the Mile 18 system to assess coho production. 


\title{
The Project
}

\section{MILE 25.25 SPAWNING CHANNEL CORdOVA RANGER DISTRICT}

\section{The Partners}

Their Contributions

\begin{abstract}
Alaska Department of Fish and Game .................................................\$3,000
Chugach National Forest ................................................................\$10,000
\end{abstract}

\section{The Benefits}

\author{
- built two escape cover structures \\ - built two sediment traps to lower siltation, recleaned channel $\mathbf{A}$ \\ - operated weirs and monitored fry production on a daily basis, from May to July \\ - monitored winter air and water temperatures \\ - conducted escapement counts \\ - worked with the ADF\&G on the recovery of coded wire tags from fish tagged in $\mathbf{1 9 9 0}$
}

\section{The Work}

Since the construction of the spawning channel in 1988 , fry production has generally declined and has been quite low in recent years. Part of this variation is due to fluctuations in the number of spawners, but the general decline is largely unexplained. A number of reasons have been considered; low water temperatures, predation of the spawners, and siltation of the substrate.

Water temperatures were monitored in the winter of 1992-93 with a Thermograph recording thermometer. Temperatures were generally $2-3^{\circ} \mathrm{C}$, although there were some periods of lower temperatures. Studies by Tang, et al. (1987) indicate these temperatures do not lead to high mortality in cold-water adapted stocks. Temperatures are being monitored again this year to see if there are large annual fluctuations.

In the past, the number of fish in the channel would drop dramatically over a few day period. It was thought that the salmon may have been eaten or chased out of the channel before spawning because of the lack of escape cover. In 1993, two additional artificial "undercut banks" were built, bringing the total cover structures to five. The structures are readily used by the salmon. The large variation in spawner numbers was not noticed in FY 1993.

The Cordova Ranger District continues to monitor and improve the Mile 25.25 spawning channel.
In 1992 and 1993, Channel A was cleaned using firehoses to combat silt buildup. In 1993, weirs were placed below each channel to compare production in the treated and untreated channels. Unfortunately, production was so low in both channels, no meaningful comparison could be developed.

Two silt traps have also been installed at the head of each channel to decrease sedimentation. Basically, these are wooden dams which have created large pool areas of low velocity where the sediments can settle. Airborne sediment collectors have also been installed to assess input into the channel from the dust from the road and from the nearby Copper River area.

Production will again be monitored from each channel to determine whether the treatment in Channel A increased survival. Redds have been marked in each channel so survival in individual redds can be determined, and the number of spawners have been counted in each channel so overall egg survival can be determined.

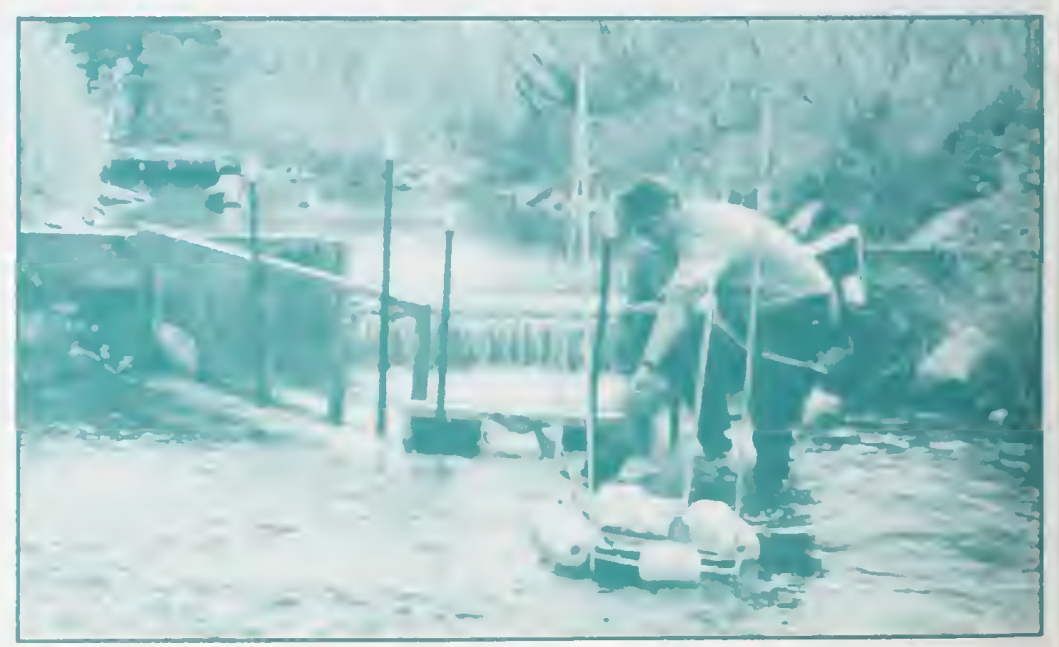




\section{The Project}

\section{Sheridan Habitat STRUCTURES CORDOVA RANGER DISTRICT}

\section{The Benefits}

- installed four log drop structures to create pool habitat and trap spawning gravel

- cabled five large trees instream to provide escape cover for spawners

- place 15 trees in pool and pond areas for cover and to increase periphyton and invertebrate production

\section{The Work}

East of Sheridan Glacier is a stream which had been part of a silty glacial system until recently. As Sheridan Glacier receded, the glacial flows changed course, leaving a clearwater stream fed by groundwater and snowmelt from the surrounding mountains. Since this area is a former glacial floodplain, the stream has almost no large woody debris and very little pool area. There are some good spawning areas in the main channel, however, and sockeye salmon, coho salmon, Dolly Varden char are colonizing this area in limited numbers.

In past years, it appeared that much of the spawning area in the main channel was being unused because of the lack of nearby escape cover. In FY'93, the District cabled five large trees (approximately 50 feet) to bedrock outcroppings near good spawning gravel. The currents flowing around the trees have created pools with tailouts where the fish can spawn, while the deeper areas of the pools and the trees provide escape cover. We have observed coho and sockeye salmon using these areas for cover, but have not yet witnessed redd digging.
The more limiting factor for coho salmon, however, is probably off-channel overwintering habitat. In a smaller tributary we built four $\log$ drop structures. These created pools below the structures, and also some spawning area in the pool tailouts and in the gravel trapped above the structure. Woody debris and boulders were placed in the pools for cover. There are also some shallow, abandoned beaver ponds which had little or no woody debris. Small trees (10-15 feet) were placed in the deeper areas to provide overwintering cover and a substrate for perphyton and insects.

Since this project was at a remote site with no road access, all of the work was done without large equipment. The larger trees had to felled into the stream or moved with a chainsaw winch. The structures could be completed in about a half-day of work with a four person crew, excluding travel time and equipment failures. This type of work was new for us, and it showed us that a substantial amount of work could be accomplished in a small stream with just a small crew and hand tools. 


\section{The Project}

\section{AMERICAN FISHERIES SOCIETY \\ COHO SALMON HABITAT WORKSHOP \\ CORDOVA RANGER DISTRICT}

\section{The Partners}

Their Contributions

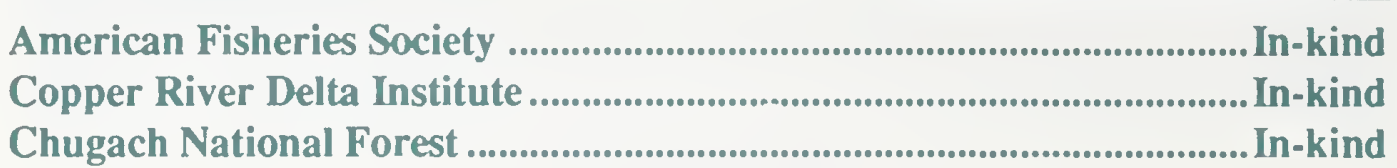

\section{The Benefits}

- recruited nationally recognized fisheries research biologists as speakers in the workshop

- workshop was a sell-out - over $\mathbf{5 0}$ biologists attended the workshop

- workshop participants represented all state and federal agencies,

private firms and the University of Alaska

\section{The Work}

The Cordova Ranger District successfully hosted the Fifth Annual Salmon Habitat Improvement Workshop. Sponsored as part of the American Fisheries Society's continuing education program, the workshop was fortunate to have as speakers some of the most well-known habitat biologists in the country, including Dr. David Hankin of Humboldt State University in Arcata, California; Dr. Gordon Reeves of the Pacific Northwest Research Station in Corvallis, Oregon; and Dr. Andrew Dolloff of the Southeastern Forest Experiment Station in Blacksburg, Virginia. These three researchers have worked together to develop the habitat survey methods which are the standard for research nationwide. Dr. Mason Bryant, of the PNW Research Station in Juneau, also spoke at the workshop. Dr. Bryant has published numerous publications on coho habitat based on research in southeast Alaska. Bryant's work is particularly relevant to the habitat questions posed by the Copper River Delta ecosystem.

The workshop also provided an opportunity to meet with speakers and other participants to exchange ideas and information on the type of work that is being done in other areas and with other agencies. As a District, we were able to present some of the work we have been doing and receive comments, criticisms, and a few answers to problems that we have encountered. In addition to Forest Service personnel, there were also participants from ADF\&G, USFWS, BLM, NMFS, a private consulting firm, and the University of Alaska.

Another important aspect of this workshop was that it gained additional recognition for the Forest Service as an agency that is involved with fisheries science and is keeping up with the latest techniques and information. If the Forest Service wants to maintain its credibility as resource managers, the biologists need to interact with other agencies and individuals on a professional level. This workshop provided an excellent opportunity for this kind of interaction. 


\section{The Project}

\section{Monitoring Fishing Pressure \\ EXPlorer CREeK AND THE RAILROAD PONDS SySTEM \\ in Portage VAlley \\ GLACIER RANGER DISTRICT}

The Partners

Their Contributions

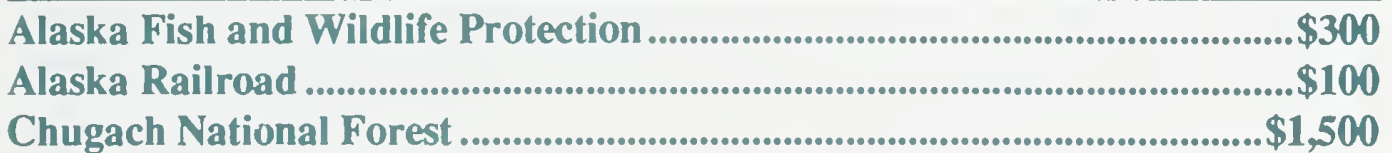

\section{The Benefits}

- fisheries monitoring and management strategy

improvement planning

\section{The Work}

In cooperation with the State of Alaska Fish and Wildlife Protection Officers, the Alaska Railroad, the Alaska Department of Fish and Game, and the Glacier Ranger District closely monitored known fishing holes for poaching and illegal limits of fish being taken.
All three partners as well as the District, made regular visits to these sites, posted signs and talked with fishermen in an effort to inform the public of fishing regulations and rules regarding access across Alaska Railroad property.

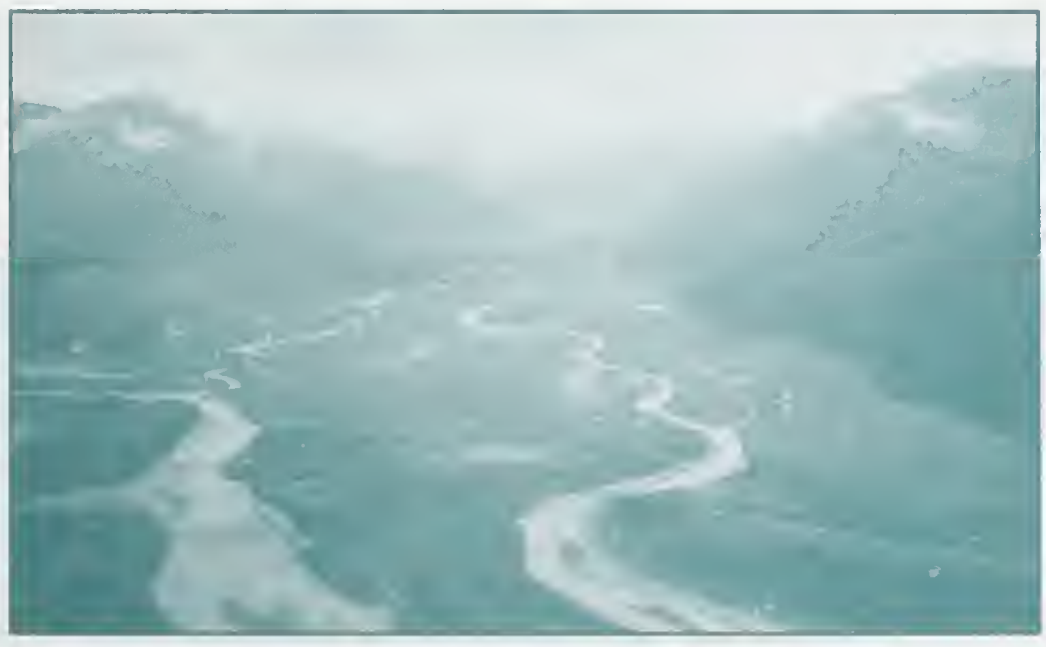

Fishing effort at the mouth of Explorer Creek on the Placer River is being monitored to protect the salmon populations returning to spawn. 


\section{The Project}

\section{Portage Valley Youth Fishing Days-Fishing Day for Physically-Challenged Youth and Adults \\ GlaCiER RANGER DISTRICT}

\section{The Partners}

Their Contributions

Alaska Department of Fish and Game ..........................................................\$4,000

Alaska Flyfishers ..........................................................................................\$200

Get Hooked on Fishing, Inc...........................................................................\$1,000

Challenge Alaska ..............................................................................................\$\$ \$700

Girdwood Summer Playground ......................................................................\$500

Chugach National Forest ........................................................................\$4,000

Trout Unlimited ..............................................................................................................\$300

Portage Glacier Lodge ..................................................................................................\$\$400

\section{The Benefits}

- cooperative fisheries and awareness

- 150 KEDs (kid education days)

- five physically-challenged fishing days

\section{The Work}

In conjunction with National Fishing Week, the Glacier Ranger District, the Alaska

Department of Fish and Game (ADF\&G), and other partners sponsored a youth fishing day at a fishing pond in Portage Valley. In June 1993, about 150 children participated in a day that focused on sportfishing, environmental education, and fishing ethics.

Alaska Flyfishers and Trout Unlimited, Inc. members assisted the anglers. The Forest Service and ADF\&G provided an environmental display with live fish, bugs, and plants from the fishing pond.

Approximately 5,000 pan-size fish were stocked by ADF\&G prior to this fishing day.
Several businesses contributed picnic supplies and fishing equipment to be won as "door prizes".

Two additional fishing days at this pond were sponsored by local organizations including the Girdwood Summer Playground, Challenge Alaska, and Youth at Risk.

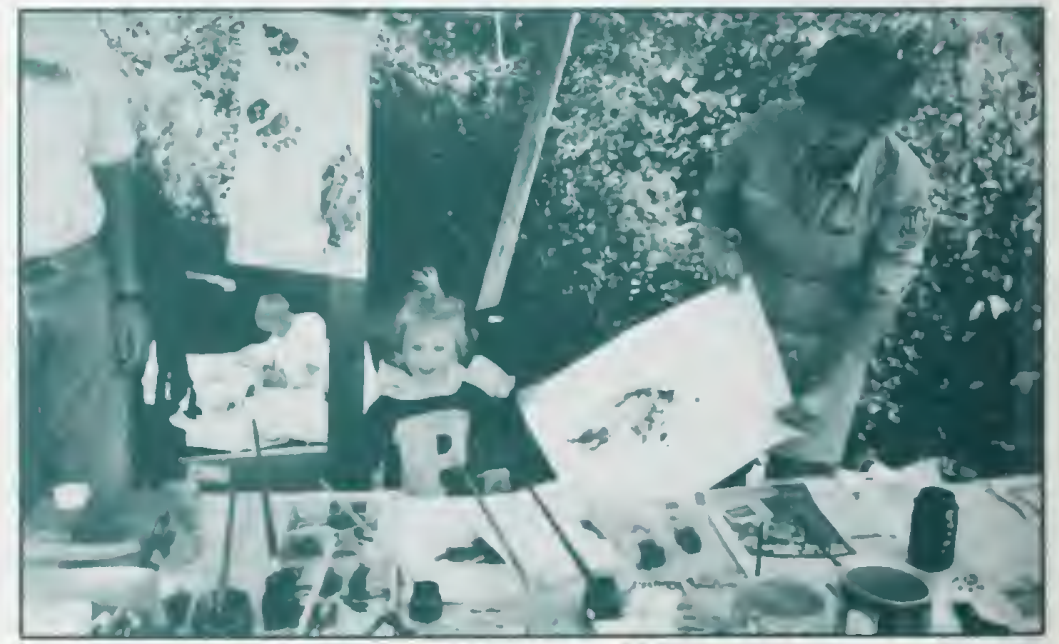


The Project

\section{Portage VALLEY RESIDENT SPORTFISH AND Wild Salmon Habitat DeVElopment Glacier Ranger District}

Anchorage Solid Waste Services .........................................................................\$5,000

Alaska Department of Fish and Game ......................................................\$3,000

Chugach National Forest ......................................................................\$5,500

Green Connection .............................................................................................................\$200

The Benefits

- resident sportfish and anadromous fish habitat improvement (20 acres)

\section{The Work}

At several locations in Portage Valley, fishery improvements are being planned and implemented in partnership with the forest's minerals program. Gravel sales and the resulting excavated ponds are the principle means of developing these improvements. Fish habitat features and other forest considerations such as recreation facilities development, wildlife habitat, and visual quality are incorporated into contract specifications for gravel removal.

Following excavation, sportfish stocking strategies developed with the Alaska Depart- ment of Fish and Game are implemented by stocking both juvenile and catchable trout. Selected ponds are also being developed to rear anadromous fish. Barrier-free fishing piers, access trails, information and interpretive signs, and day-use recreation facilities are being developed.

In 1992, 20 acres of fish habitat was created or improved. In existing ponds, approximately 5,000 rainbow trout were stocked. District staff are monitoring both the sportfishery use of these areas and the growth and survival of stocked fish.

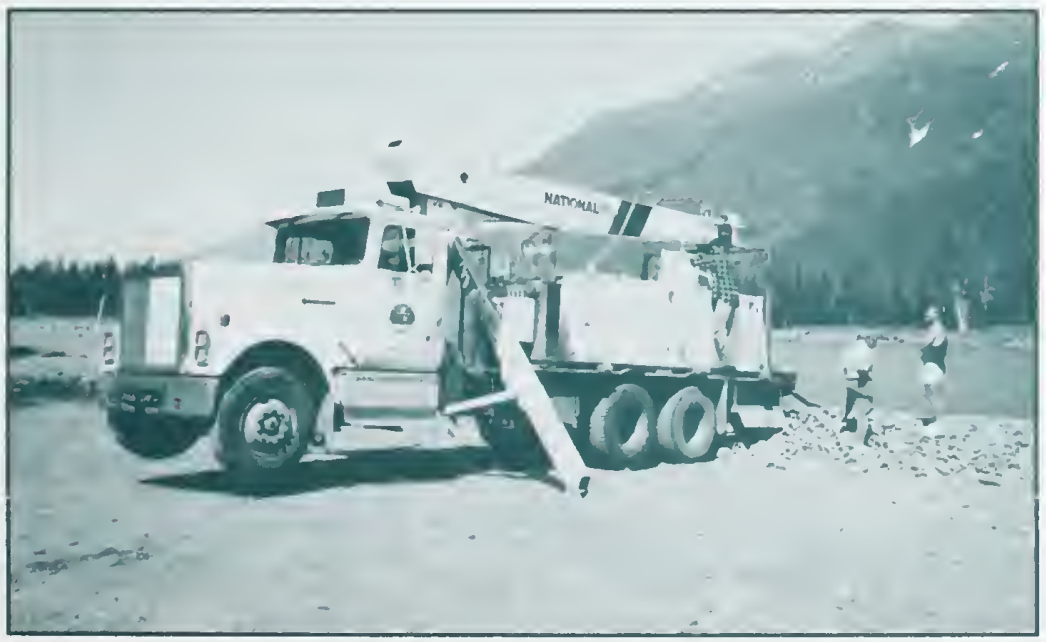

Fishing ponds are stocked with rainbow trout by $A D F \& G$. 


\section{The Project}

\section{Western Prince William Sound Fishway \\ MAINTENANCE AND MONITORING \\ GLACIER RANGER DISTRICT}

\section{The Partners}

Their Contributions
Alaska Department of Fish and Game
$\$ 7,000$
Chugach National Forest $\$ 13,000$

\section{The Benefits}

- maintain and monitor fishway structures

\section{The Work}

The Glacier Ranger District currently maintains and operates 12 fishway structures in Prince William Sound. Maintaining these structures in operating condition is a high priority. While past efforts have been adequate in maintaining operational fishways, limited information has been collected regarding the effectiveness of these structures and their overall contribution to the fishery.
Biologist plan modification of fishway in Prince William Sound.
Monitoring plans have been developed and acquisition of data bases developed by $A D F \& G$ is proceeding. These will enable us to better evaluate the projects and make recommendations for improving wild stock salmon production. Monitoring will continue in 1994.

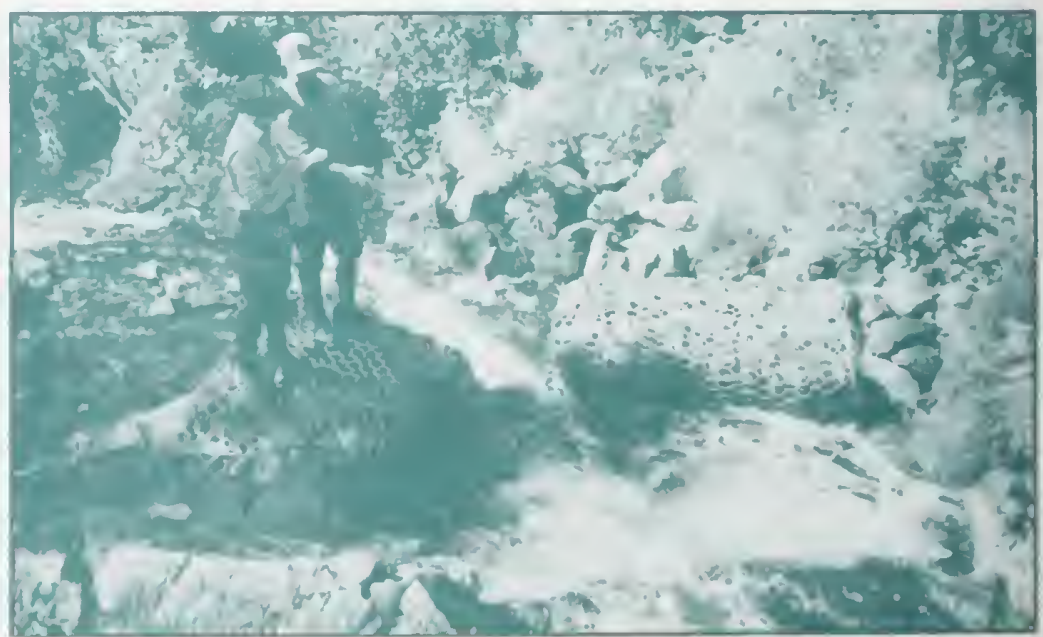




\section{The Project}

\section{Girdwood Valley Fish Monitoring Project GlaCIER RANGER DISTRICT}

\section{The Benefits}

- fisheries monitoring and management strategy

\section{The Work}

Partners in this activity included the Alaska Department of Fish and Game (ADF\&G), and the Girdwood Community. Residents of the Girdwood Valley organized a group to conduct juvenile and adult counts and creel census. The ADF\&G supplied the Girdwood Fish Group with signs pertaining to regulations to be placed at local fishing holes and known spawning or holding areas.

Residents of the Girdwood Valley organized a group to conduct juvenile and adult counts and creel census' on the main streams in the Girdwood Valley. The goal was to get information on what species reside in these streams, the upper limits of the species' range, how many adults returned to these systems and what kind of fishing pressure they sustain.

The ADF\&G will use this information for amending fishing regulations, permitting of use along the creeks and determining if stocking will be considered in the future. 


\section{The Project}

\section{Coghill LAKe CoOperative FerTilization AND \\ SOCKEYE SALMON ENHANCEMENT \\ GlaCier RANGer District}

\section{The Partners}

Their Contributions

Alaska Department of Fish and Game.

$\$ 104,000$

Prince William Sound Aquaculture Corporation $\$ 500$

Chugach National Forest $\$ 64,000$

\section{The Benefits}

- increase sockeye run from low of 7,000 to historical run of 200,000-300,000

returning adult sockeye per year

- 80 days of recreational fishing at the lake and $\mathbf{1 0 0}$ days fishing

at nearby saltwater per year

\section{The Work}

Coghill Lake in Prince William Sound has historically provided a significant contribution to the commercial, subsistence, and sportfisheries for sockeye salmon in Port Wells. It is believed that the salmon fry and smolt decimated their zooplankton food source.

Fertilization has been recommended for the lake to restore the rearing environment.

The Alaska Department of Fish and Game (ADF\&G) and the Prince William Sound Aquaculture Corporation area active partners in this project.
In 1993, 55 tons of fertilization were applied to the lake to jump start the nutrient cycle. Fertilization will continue until monitoring indicates the zooplankton food base has recovered.

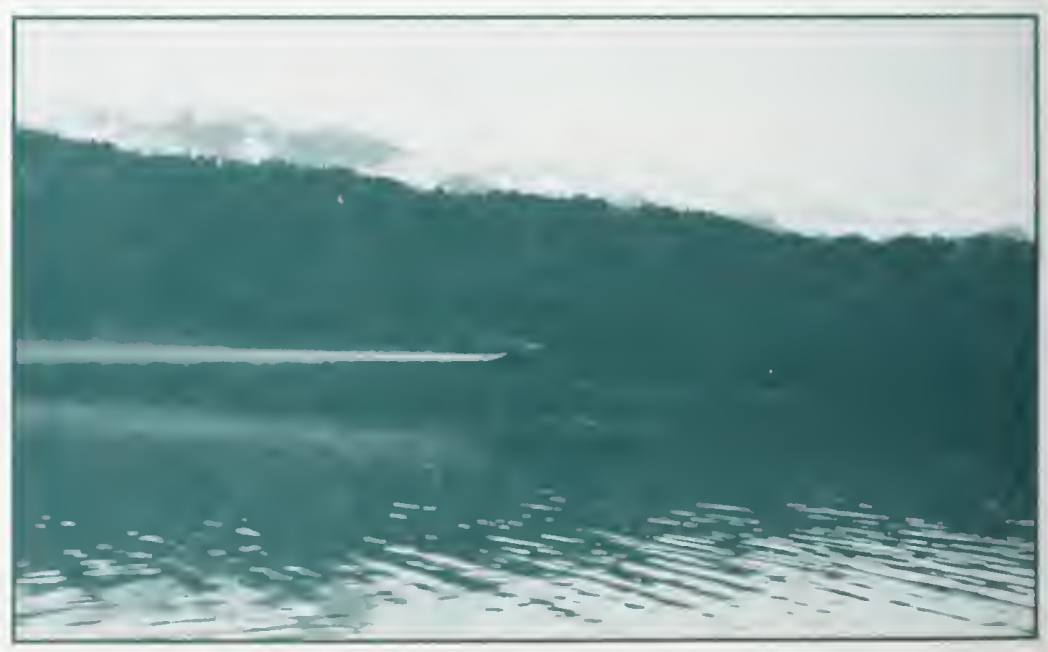




\section{NATURAL \\ RESOURCE \\ CONSERVATION \\ EDUCATION}




\section{The Project}

\section{Chugach Region Elder-Youth Conference CORDOVA RANGER DISTRICT}

\section{The Partners}

Their Contributions

Chugachmiut .(In-kind) \$20,511

Chugach National Forest $\$ 23,546$

\section{The Benefits}

- informing Native communities of FS programs and employment possibilities - communicating more effectively with Native communities

- increased Heritage-based insight into contemporary social problems

- learning more about the cultural heritage of the Chugach Native peoples as means of developing pride and self-esteem among these peoples

- enhancing interest and understanding of values inherent in protecting historic and archaeological sites and natural resources.

\section{The Work}

Chugach Native youth are at high risk for social problems, including depression, unemployment, teenage pregnancy, and suicide. This conference was put together as a forum to connect youths with Elders to bridge the gap between extant Native culture and the many and divergent distractions pulling on today's Native youths. This would also provide Elders with a sense of usefulness and purpose. The idea was to help create an atmosphere in which the meanings of being a Native in Alaska transcend the negative connotations and denotations of the recent historical past, providing a sense of connectedness with a deep and rich cultural heritage.

Through presentations and one-on-one caucusing, the 100 attendees were able to air the problems experienced by Native people in the Chugach Region and then put energy into developing ideas on how to improve their individual and collective lot. The Forest Service presented a welcome from the Cordova Ranger District (Cal Baker, District Ranger), information on employment possibilities (Virginia Sears, SO), and the Heritage Program (Fred Clark, SO). This was a great opportunity to let people know about the diversity of activities undertaken by the Forest Service. All participants went away with a much more positive view of the Forest Service and an understanding that the Forest Service is involved in many areas of interest to Native people of Prince William Sound. 


\section{The Project}

\section{Arbor Day Tree Planting Program SEWARD RANGER DISTRICT}

The Partners

Moose Pass School Chugach National Forest
Their Contributions ...(In-kind) $\$ 1,000$ $\$ 2,000$

\section{The Benefits}

- 20 KEDs (kid envionmental days)

- more than $\mathbf{5 0 0}$ white spruce seedlings planted.

\section{The Work}

About 20 kids from the Moose Pass School participated in an Arbor Day tree planting program with the Seward District Foresters. Over 500 spruce scedlings were planted in the
Tenderfoot Campground, where spruce bark beetles have killed most of the mature trees. The kids learned about bark beetles and reforestation techniques. 


\title{
The Project
}

\author{
KIDS FISHING DAY \\ Seward Ranger District
}

The Partners

Their Contributions

National Fishing Week \& Hooked on Fishing International $\$ 300$

Country Time Lemonade (In-kind) $\$ 100$

The Fish House $\$ 300$

Seward Phoenix Log $\$ 50$

KSWD Radio $\$ 100$

Chugach National Forest Campground HOST Volunteers $\$ 500$

Chugach National Forest $\$ 1,000$ Sport Fishing Institute $\$ 250$

\section{The Benefits}

- 50 KEDs (kid environmental days)

\section{The Work}

In conjuction with National Fishing Week, the Seward Ranger District held its second annual "Youth Fishing Day" at Lower Summit Lake. The days activities included an interactive learning session on fish adaptations by interpretive specialist Kay Toth-Stauble where children constructed very creative fish from craft supplies; the "Pathways to Fishing"

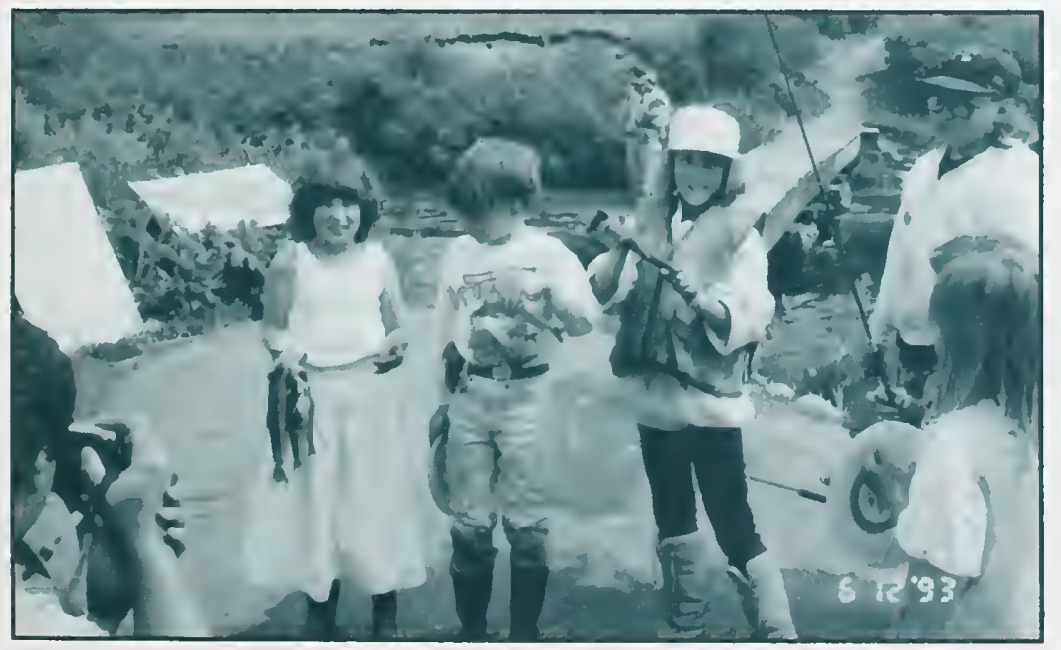

program on fishing basics, catch and release techniques, and lake ecology; an appearance by Sammy the Salmon; and, of course, plenty of fishing. At day's end the district's campground HOSTS provided a hot dog cookout followed by a prize drawing. All fishing gear used during the day and many of the prizes were donated by The Fish House and the Sport Fishing Institute. Several campground HOSTS provided boats to fish from for the day. The Seward Phoenix Log and KSWD Radio provided free advertising during the week prior to the event.

Several young anglers show off their catch of Dolly Varden; "Pathways to Fishing" materials are in the background. 


\title{
The Project
}

\section{ENVIRONMENTAL AWARENESS DAYS \\ at MoOse PaSs AND Hope, AK \\ SEWARD RANGER DisTrict}

\section{The Partners}

Their Contributions

\author{
Cooper Landing, Hope, Moose Pass, and \\ Seward Elementary Schools \\ (In-kind) $\$ 3,000$ \\ Chugach National Forest .......................................................................................\$3,000
}

\section{The Benefits}

- 120 KEDs (kid environmental days)

\section{The Work}

Each May, Environmental Awareness Days (EAD) is a spring event for all elementary schools on the Seward Ranger District. A full day is devoted to "hands on" outdoor learning in such subject areas as wildlife, fisheries, minerals, forest health, fire, and forest history. The curriculum is targeted for grade 5, and students rotate through a six-station loop set up in the Ptarmigan Creek Campground. Each presentation is approximately 20 minutes long.
Through interactive participation with district specialists, students become salmon in a game of "Hooks and Ladders," pan for gold in Ptarmigan Creek, search for bugs in a decaying tree, and practice firefighting techniques. Other presentations include a live bird demonstration from the Bird Treatment and Learning Center in Anchorage, and a demonstration on antique carpentry skills with native woods.

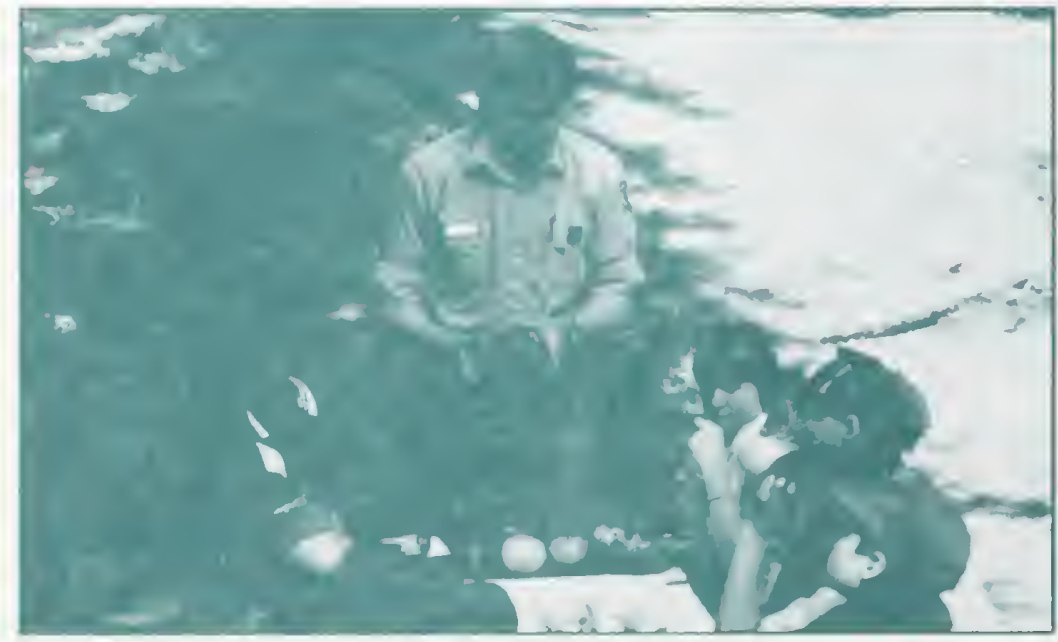

Environmental Awareness Day Ptarmigan Creek Campground 


\section{The Project}

\section{SeWard Parks and Recreation Day Camp SEWARD RANGER DISTRICT}

\section{The Benefits}

- 45 KEDs (kid environmental days)

\section{The Work}

The City of Seward Parks and Recreation Department sponsors a summer camp for grade-school-aged children. The Seward
Ranger District provided a variety of programs in natural resource conservation education, including programs on recycling and "green" consumerism. 


\section{The Project}

\section{Cordova Science Club \\ CORdOVA RaNGer DISTRICT}

\section{The Partners}

\section{Their Contributions}

Prince William Sound Science Center

$\$ 3,500$

Bidarki Recreation Center

(In-kind) $\$ 1,000$

Chugach National Forest (In-kind and cash grant) $\$ 3,000$

Copper River Delta Institute

(In-kind) $\$ 1,000$

\section{The Benefits}

- Natural Resource Conservation Education program that provided 900

KEDs (kid environmental days)

The Work

The after school Cordova Science Club is a natural resource education program for kindergarten through 6th grade students. It is designed to encourage a child's curiosity about the natural world and - through hands-on learning experiences - foster the idea that science is fun.

The science club's activities are designed to enhance the school's science curriculum while emphasizing local ecosystems and the scientific phenomena found in everyday life.

Hands-on discovery learning and field trips are an integral part of the program.

During science club meetings, children conduct simple experiments to answer questions such as: Why do leaves fall from trees? Why is dark so long during Alaskan winters? What are ways that animals adapt to their environment?

The science club meets weekly with approximately 60 students divided into three age groups. The Forest Service supports the program with cash grants and support from district staff. 


\section{The Project}

\section{Natural ReSOURCE CoNSERVATION EDUCATION FOR PRINCE WiLliam SOUND CORdOVA RANGER DISTRICT}

\section{The Partners}

Their Contributions

Prince William Sound Science Center $\$ 3,500$

ARCO $\$ 5,000$

Cordova Ranger District (In-kind) $\$ 2,000$

USDA Forest Service NRCE Grants $\$ 3,000$

Prince William Sound Community College In-kind

Glacier Ranger District In-kind

Chugach School District In-kind

\section{The Benefits}

- initiated partnerships with the Alaska Native villages of Chenega and Tatitlek, and the community of Whittier - designed and conducted one month of NRCE activities for Chenega, Tatitlek, and Whittier. - worked with Prince William Sound Science Center and the Glacier Ranger District to implement program

- project has received national recognition (1993 National Eyes on Wildlife Award) and several supporting grants

(ARCO, British Petroleum, Alyeska, and Forest Service NRCE Grants)

\section{The Work}

A key component of the "Science of the Sound" NRCE program is the Cordova Discovery Room. This successful program forms the cornerstone of the community's NRCE efforts.

Although the program reaches nearly $100 \%$ of Cordova children, ages 3-12, we have not been able to work with children from outlying villages and communities. Children from Valdez and Whittier, and the Alaska Native villages of Tatitlek and Chenega have not been served by Cordova's NRCE efforts.

The Cordova Ranger District has emphasized improving Forest Service public service to communities in Prince William Sound

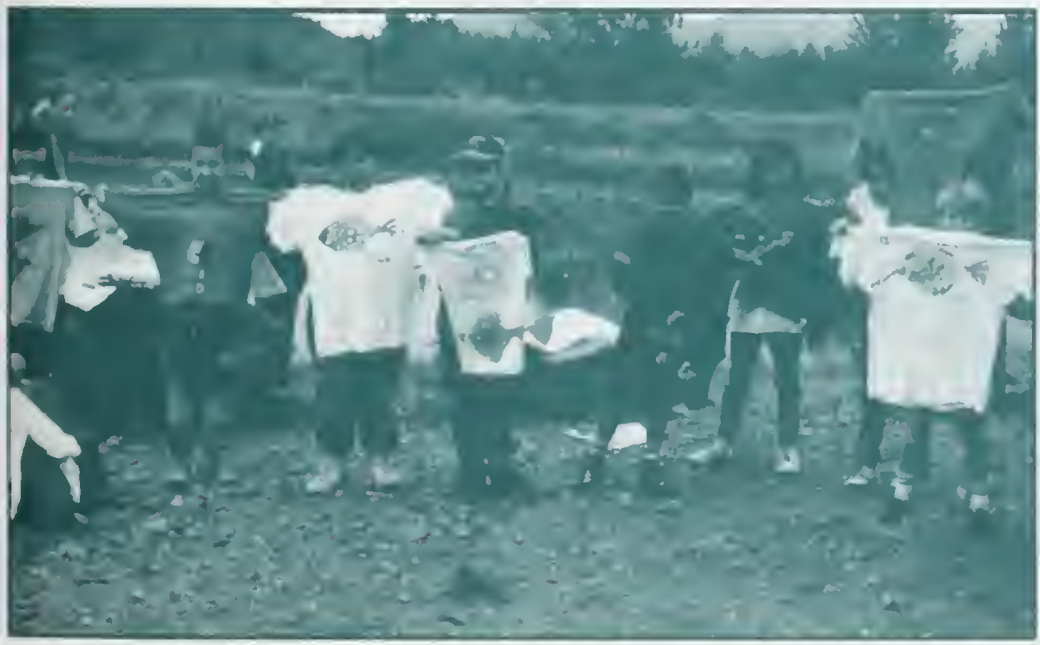

(PWS). This NRCE project targets children in these communities. Many of these children are intimately in-touch with the natural environment, but may have limited access to NRCE activities and resources. The "Science of the Sound" NRCE Program is reaching out to these communities by bringing children to Cordova AND by sending resources to the PWS communities.

The goal of the PWS NRCE program is not only to provide relevant NRCE activities to PWS children, but also to provide the support and training necessary for communities to establish their own NRCE efforts.

The Cordova Ranger District and the Prince Williams Sound Science Center initiated this successful program in 1993. During spring, facilitators visited the Native villages of Chenega, Tatitlek, and the isolated community of Whittier. For FY 1994, the program has been partially funded through a $\$ 15,000$ grant from ARCO. Facilitators plan to visit Prince William Sound communities at least four times during the 1993-1994 school year. 


\section{The Project}

\section{NATURAL RESOURCE CONSERVATION AND \\ Environmental EduCation Programs \\ (SPECIAL Groups AND EVENTS) \\ Glacier Ranger District}

\section{The Partners}

Their Contributions

Winter Tourism Fair In-kind

Corvallis School District In-kind

YMCA of Anchorage In-kind

Bird Treatment and Learning Center In-kind

Anchorage School District In-kind

Sportsmans Show In-kind

Salvation Army In-kind

Serendipity In-kind Chugach National Forest (salary) $\$ 16,000$

\section{The Benefits}

- to be exposed to groups that would slip through the cracks if it weren't for special events and outside groups

\section{The Work}

The Glacier Ranger District extend their normal programming to do special programs that will promote the community and the National Forest. Some of these programs are environmental and others are entertaining for both the young and oid with a variety of media being used. Many programs were developed from the surrounding landscape to show how each of us can make a contribution to help preserve our future which includes recycling aluminum cans to good camping ethics. Many organizations help to organize and offer a place where our employees can go out and present these programs to visitors and other alike. 
NATURAl ResourCe Conservation and ENVIRONMENTAL EduCATION Program (SCHOOLS) GLACIER RANGER DISTRICT

Anchorage School District (FS paid) In-kind

Sheldon Jackson College, Sitka, AK. In-kind

Sitka School District. In-kind

Alaska Pacific University In-kind

North Side School, Colorado In-kind

Petersburg School District

Tuskeegee Institute, Alabama (FS paid) In-kind

Delta Junction Schools (FS paid) In-kind

Chugach National Forest .In-kind (salary) $\$ 15,000$

\section{The Benefits}

- over 150 educational and interpretive programs were presented to a variety of audiences

\section{The Work}

The Glacier Ranger District reaches out to both local and not so local communities providing interpretive and educational programs throughout the year. In 1993, over 150 presentations were made to school groups ranging from first grade to university students.

Programs ranged from living history, interpretation to outdoor survival, and typical nature lore. These partnerships were responsible for introducing many school children and students of higher education to the Glacier Ranger District, the Chugach National Forest and the Forest Service. 


\section{The Project}

\section{CORDOVA DISCOVERY ROOM \\ CORDOVA RaNGER DISTRICT}

Their Contributions

Prince William Sound Science Center $\$ 5,000$

Prince William Sound Community College (In-kind) $\$ 3,000$

Cordova Public Schools In-kind

USDA Forest Service NRCE Grants $\$ 3,000$

Copper River Delta Institute $\$ 1,000$

Chugach National Forest $\$ 5,000$

Local volunteers (In-kind) $\$ 2,000$

Alaska Department of Fish and Game In-kind

ARCO $\$ 9,000$

National Fish and Wildlife Foundation $\$ 8,000$

\section{The Benefits}

- provided over 2,700 hours of educational contact for Cordova children - program received national recognition and financial support (1993 Eyes on Wildlife Award, grants from ARCO, BP, Alyeska, and FS NRCE program)

\section{The Work}

The Cordova Discovery Room is a unique cooperative program between the Cordova Ranger District, Prince William Sound Science Center, Prince William Sound Community College, and the Cordova School District. The Discovery Room was developed as a stimulating environment for students and adults to explore various areas of the natural sciences.

During Fall 1992, a room at the Prince William Sound Community College was transformed into a hands-on leaming "imaginarium". Each month, over 300 preschool - sixth grade children attend Resource Room programs facilitated by Forest Service and Prince William Sound Science Center Staff. The program reaches approximately
$95 \%$ of pre-school - sixth grade children including home schoolers.

The Discovery Room is a learning center filled with displays which students can touch, explore, manipulate and observe. Monthly themes, developed by a committee of local teachers and Prince William Sound Science Center/Forest Service staff, complement the elementary school's science curriculum. These themes, intended to coordinate with other activities such as family science night and the After-School Science Club, have included local plants, animal cycles, preparing for a delta winter, animals sights and sounds, weather and astronomy, and local geology. 
Teachers and home-schooling parents bring their classes/children to the Discovery Room, monthly for an hour "discovery" session. Three staff persons team-teach the monthly programs.

During their action-packed hour at the Resource Room, students participate in an involving puppet show which introduces the day's theme, and then rotate through three separate NRCE activities. Many of the month's programs are structured around the educational framework of Project WILD NRCE curriculum. Project WILD and PLT materials are often used in the monthly program.

The program has been supported through a series of grants and fund-raising efforts. In addition to the small grant requested through the Forest Service NRCE Grant program, monetary support is being requested through the EPA Environmental Education Grant program. With additional funding, the Discovery Room's monthly themes provide the framework for:

- Monthly field trips for families to explore these themes.

- The development of teacher education kits based on the monthly themes which would include; background information on the topic,

Cordova children had the opportunity to explore Cordova's resources during FY 1993 "Discovery Room" NRCE activities. an activities outline, materials for activities and projects, teacher guide for the use of materials and extension ideas for incorporating the monthly theme into their classroom in a cross-curricular manner.

Production of educational kits provides the teachers with a means of accessing hands-on, locally relevant materials for exploring science and natural resource issues in their classrooms. Three kits are available for loaning whenever a teacher needs this resource.

The kits also provide the means for developing a permanent collection of educational materials that could be used on a rotating basis in the Discovery Room. The kits will be used by the Science Center and Forest Service staff in a village outreach program to bring natural resource education to villages and communities in Prince William Sound.

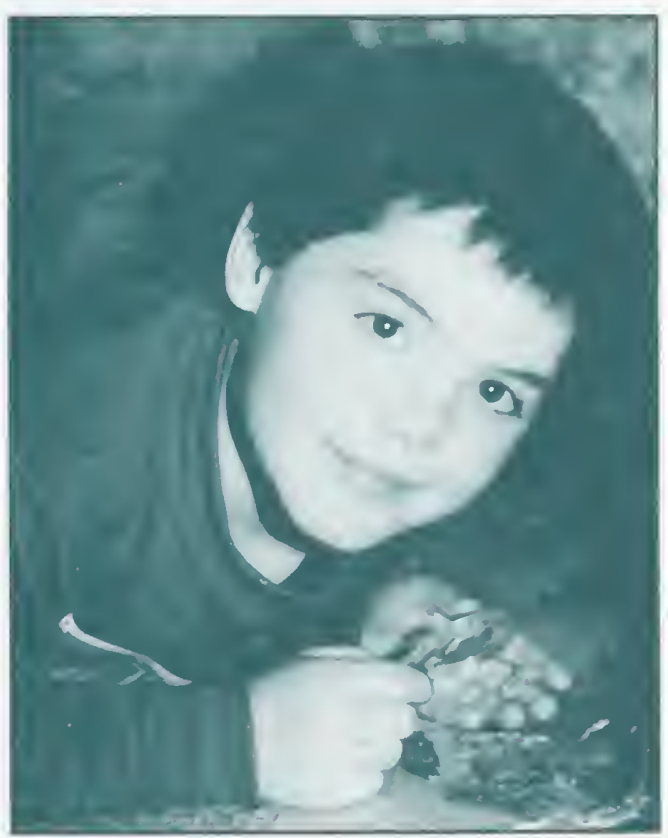




\section{The Project}

\section{KIDS FISHING DERBY \\ CORdova Ranger DISTRICT}

\section{The Partners}

Their Contributions

Moose Club.

(In-kind) $\$ 1,000$

Local volunteers In-kind

Elks Club. In-kind

Cordova Times (In-kind) \$200

U.S. Postal Service In-kind

Cordova Visual Artists .In-kind

KLAM Radio (In-kind) $\$ 300$

Cordova Public Schools .In-kind

Chugach National Forest. $\$ 500$

Area businesses. $\$ 500$

\section{The Benefits}

- more than 100 Cordova children participated in the fishing derby

- 40 children participated in the casting derby

- 20 children participated in the poster contest

- 150 KEDs (kid environmental days)

\section{The Work}

In conjuction with the Chamber of Commerce's Silver Salmon Derby, the Cordova Ranger District sponsored a children's casting contest during the Children's Fishing Derby in September 1993.

Three Cordova Ranger District staff officiated at the casting site and awarded prizes provided by sponsors. Forest Service staff assisted the derby's organizers with natural resource education, weighing fish, untangling lines, and flipping hot dogs.

Sammy the Salmon was on hand to cruise the fishing grounds and greet anglers.

To promote responsible sportfishing habits, the Cordova Ranger district also sponsored a "smart fishing" poster and mobile contest for kids. Entries were judged on how well they addressed one of the following four fishing ethics: obey the catch limit, handle fish gently if you plan to release them, don't leave fishing line or trash at your site, and clean your catch in the water. The winning entries were proudly displayed in the Cordova Post Office. The artists were treated to new tackle boxes and prizes donated by area businesses.

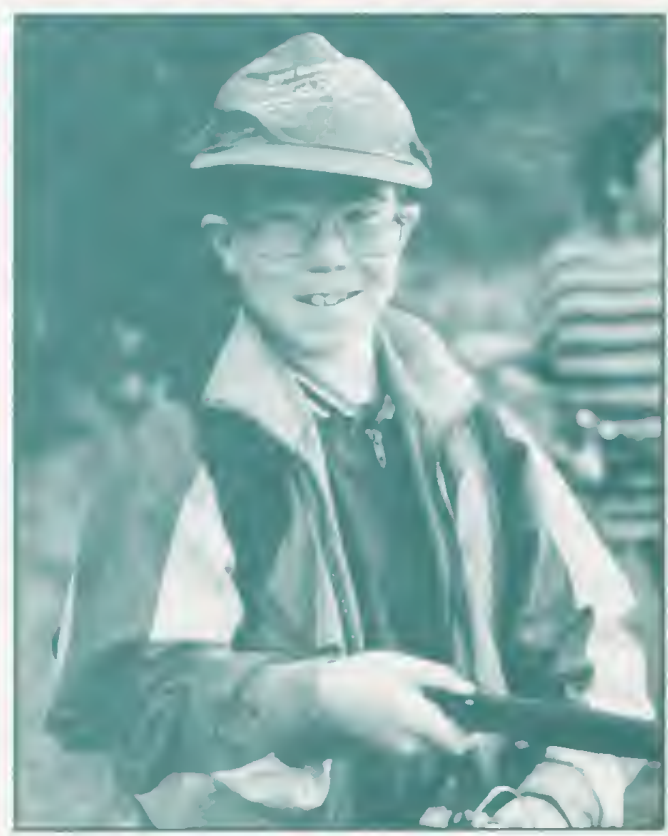

Happy angler! 


\section{The Project}

\section{INTERNATIONAL MIGRATORY BIRD DAY GLACIER RANGER DISTRICT}

\section{The Benefits}

- approximately 100 Education Days

- brochure highlighting statewide events

\section{The Work}

In celebration of the first annual International Migratory Bird Day on May 8, 1993, the district coordinated two events. Bird identification assistance was provided by the district,

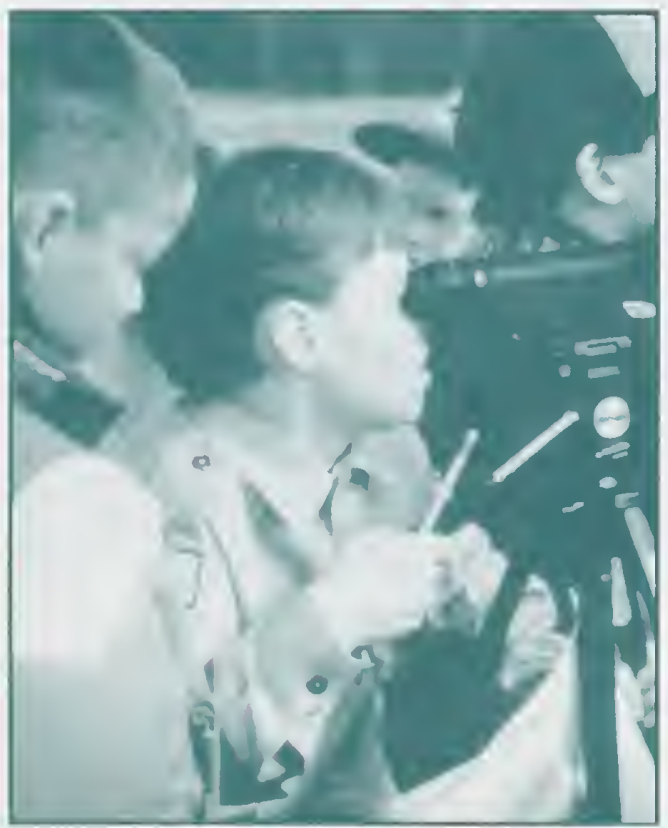

ADF\&G, and USFWS biologists at Potter Marsh the morning of May 8, and during the afternoon, a netting and indentification/ banding demonstration with the USFWS was provided at Williwaw Campground. Together these events provided approximatley 100 Education Days. The district is an active participant of Boreal Partners in Flight Education and Information efforts, and as IMBD state coordinator, the district developed a schedule of statewide events, which was distributed at USFWS refuges, other National Forests, at Alaska's Earth Fair and events across the state.

Boyscouts getting their "Naturalist" badges at Potter Marsh on International Migratory Bird Day, May 8, 1993, with the help of USFS, US Fish \& Wildlife Service, and Alaska Department of Fish \& Game biologists. 


\title{
The Project
}

\section{4-H FORESTRY CAMP \\ CORdova RaNGer DisTriCT}

\section{The Partners}

\section{Their Contributions}

\author{
University of Alaska Cooperative Extension Service.....................................\$5,000 \\ USDA Forest Service NRCE Grant ..............................................................\$\$,000 \\ Cordova Ranger District ....................................................................(In-kind) \$3,000 \\ Local business leaders....................................................................... In-kind
}

\section{The Benefits}

- helped plan, organize, fund, and implement the first $4 \mathrm{H}$ camp offered in the Prince William Sound area.

- provided over 35 children with a five day natural resource conservation

education $(1,400$ hours of education contact).

- worked closely with a variety of community and regional partners to provide factual, unbiased information about area resources and resource conflicts.

\section{The Work}

The University of Alaska Cooperative Extension Service 4-H Youth Development Program, in conjuction with the Cordova Ranger District, Prince William Sound Science

Center, and other resource agencies organized and implemented a four night/five day natural resources camp in Cordova during June 1993.

The mission of 4-H is to assist youth in acquiring knowledge, developing life skills, and forming attitudes which enable them to become self-directing, productive, and contributing members of society. Because of the motivation and enthusiasm of the learners, the intensity and intimacy of the experience, and the emphasis on cooperative group living, 4-H natural resources camp will offer high potential for achieving this mission.
Forestry issues are at the forefront of regional issues. Students need to learn the facts behind the news stories. This can be best accomplished by meeting decision makers and doing their own research.

Cordova is an ideal place for a camp focusing on forestry issues because of the unique combination of policy-makers in the area. A logging company, two Alaska Native village corporations, the Chugach National Forest, and the Alaska Department of Fish and Game are all located in Cordova.

During the camp, students investigated Prince William Sound forestry issues; local logging efforts; wood products uses, conservation measures, timber sales, and proposed timber buybacks with Exxon Valdez Oil Spill Settlement funds. 
The camp was divided into two parts. First, boys and girls, ages 9-13 acquired awareness, appreciation, understanding, and knowledge about the unique resources of Prince Williams Sound through hands-on experiences with foresters, wildlife managers, soil scientists, recreation specialists, researchers, planners, loggers and Alaska Natives. Both Project Learning Tree and Project WILD curricula were used in the education efforts. The second portion of the camp capitalized on the experiences and knowledge acquired earlier to develop critical thinking, problem-solving and decision-making skills on a specific area accessible by the road system in the Cordova area.

Thirty-five youth, including children from Prince William Sound villages, Cordova, and

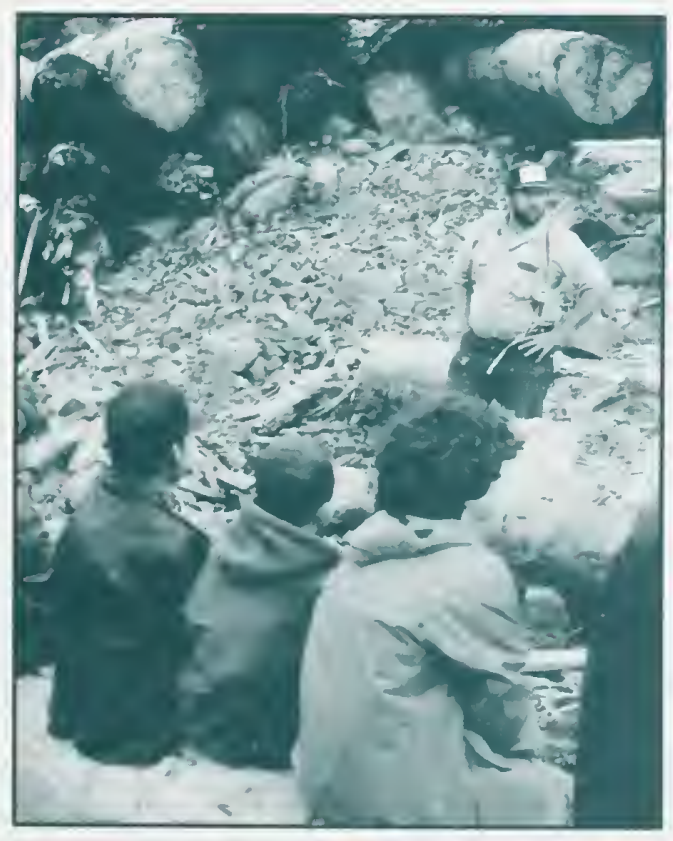

Area children had the opportunity to explore forestry and fishery issues during the first $4 \mathrm{H}$ camp in Prince William Sound.
Palmer were involved in the camp. Six high school students, experienced in natural resource research were counselors and crew leaders.

During the course of the camp, both campers and crew leaders were exposed to a wide variety of resource professionals who demonstrated and described their natural resource related careers.

The 4-H Natural Resources Camp established a new tradition of natural resource education through camping in the Cordova and Prince William Sound area. Campers acquired not only awareness, knowledge, and a better understanding of resource issues, but were also committed to making better informed decisions and promoting constructive, creative solutions to forest resource issues. 


\section{PUBLIC INFORMATION AND \\ INTERPRETATION}




\section{The Project}

\section{Search for Historic Russian Plates \\ in Prince William Sound \\ CORdOVA RANGER DISTRICT}

\section{The Partners}

Their Contributions

The Marine Academy of Vladivostok In-kind Chugach National Forest .........................................................................................\$1,600

\section{The Benefits}

- increased international partnership in the history of Russia America

- field verification of historical descriptions, using sources in both

Russian and English languages

- verification of changes in land forms and likelihood of artifact removal

\section{The Work}

Dr. Leonid Lysenko of the Marine Academy of Vladivostok and his crew, Alexander Abramov (sailing master), and Alexandre Vykhrictiock (Journalist for magazine "Around the World"), sailed the 45 foot vessel Admiral Nevelskoi to Alaska to locate, if they could, a series of "possession plates" buried by Gerasim Izmailov in 1788. The two plates in Prince William Sound were numbers seven and eight and were intended to claim the area for Russia, thus reinforcing the right of first discovery made by Bering and Cherikhov's Alaskan landfall in 1741 on Kayak Island.

Fred Clark, an archeologist at the Supervisors Office (SO), joined with the Lysenko expedition on August 16 and provided technical assistance and facilitation for the expedition until August 23. Lysenko had texts in Russian and copies of historic maps relating to the original placement of the plates. The Admiral Nevelskoi served as transportation and base of operations. The SO provided two metal detectors (one for ferrous metals and one for non-ferrous metals). The Cordova Ranger District provided logistical support and the use of a small inflatable boat and motor. No possession plates were found, but should new information surface in Russian archives, we will have the base of a productive partnership in place for future search. 


\section{The Project}

\section{Tern Lake Wildlife Viewing Platform SEWARD RaNGER DISTRICT}

\section{The Partners}

Their Contributions

Foundation for North American Wild Sheep $\$ 2,000$

Chugach National Forest $\$ 30,000$

USDA Forest Service (Regional Office) $\$ 2,000$

\section{The Benefits}

- one viewing platform

- four interpretive signs

\section{The Work}

Thousands of tourists pass Tern Lake each year. By improving an existing pullout and constructing a small elevated viewing platform, the Seward Ranger District can improve

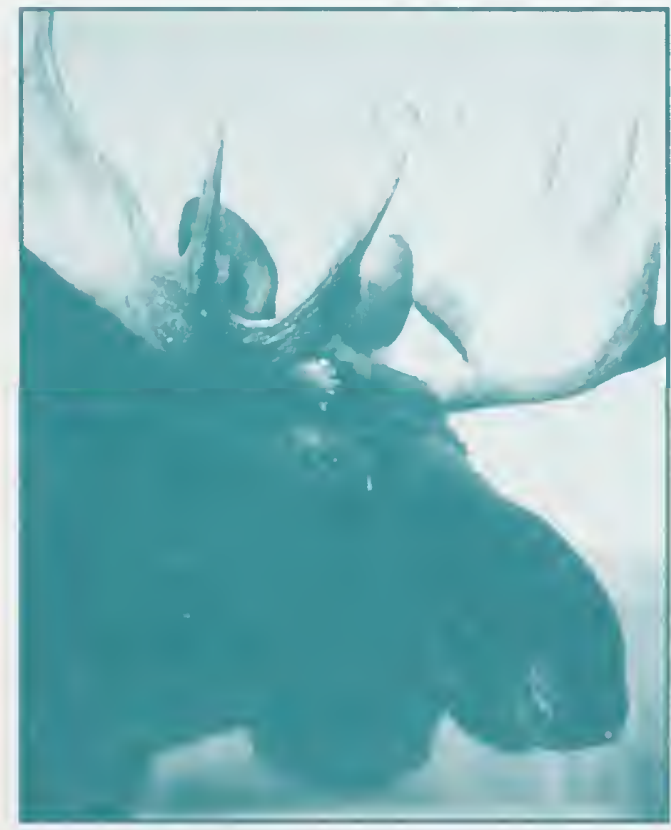

the wildlife viewing opportunities that abound there. The Tern Lake project is the first in a series of watchable wildlife projects that will profile the link between habitat and wildlife viewing. 


\section{The Project}

\section{Monofiliment Fishing Line Recycling Program \\ SEWARD RANGER DISTRICT}

Their Contributions

Berkeley Fishing Line Corporation ..........................................................................\$200

City of Seward - Harbormaster's Office ..............................................................\$100

The Fish House ...................................................................................................................\$50

Seward Post Office ...........................................................................................................\$100

Chugach National Forest .........................................................................................\$400

Kenai Fjords National Park ............................................................................................\$400

\section{The Benefits}

- six monofilament line recycling bins at Russian River angler trail access points

- four monofilament line recycling bins at Seward Harbor

\section{The Work}

Berkeley's nationwide program of providing fishing tackle retail outlets with bins to collect monofilament fishing line has been taken one step further on the Seward Ranger District. To curb the amount of monofilament fishing line left along the banks of the lower Russian River, the Seward Ranger District installed six monofilament line collection bins at angler trail access points leading from the Russian
River Campground. Fisheries technician Larry Winter constructed recycling bins listing the dangers discarded line pose to fish and wildlife, along with the uses of the recycled line.

In cooperation with Kenai Fjords National Park and the Seward Harbormaster's Office, four line recycle bins were located at access ramps to the Seward Boat Harbor. 


\section{The Project}

\section{RUSSIAN RIVER/KENAI RIVER CATCH AND \\ RELEASE RAINBOW POSTER \\ SEWARD RANGER DISTRICT}

\section{The Partners}

Their Contributions

Trout Unlimited

(In-kind) $\$ 300$

Alaska Department of Fish and Game -Sportfish Division (In-kind) $\$ 300$

Kenai National Wildlife Refuge $\$ 1,000$

Chugach National Forest

\section{The Benefits}

- profile Trout Unlimited and multi-agency memorandum of understanding partnership developed in August 1991

- poster will educate anglers on the proper technique of catch and release

\section{The Work}

The Alaska Chapter of Trout Unlimited (TU) contacted the Forest Service in spring 1992 about developing a catch-and-release poster targeting rainbow trout and Dolly Varden fisheries in the upper Kenai River drainage.

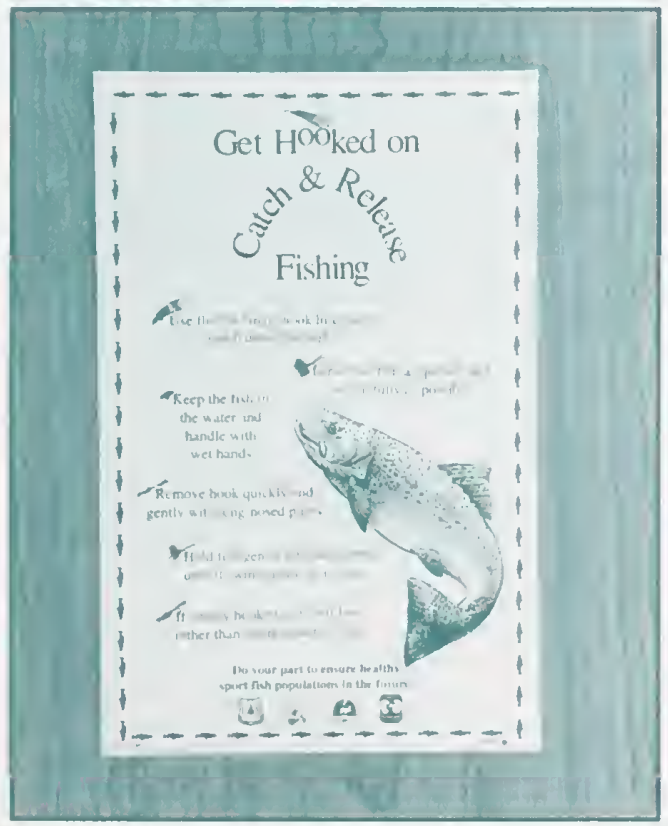

Increased sportfishing in the late 1980 s for trophy-size rainbow trout and Dolly Varden in the upper Kenai River prompted the Alaska Department of Fish and Game (ADF\&G) in 1991 to adopt a new regulation that greatly increased the practice of catch-and-release fishing.

The Seward Ranger District coordinated the development of the poster and involvement by partners. Text for the poster was modified from excerpts of the ADF\&G/TU Catch and Release Brochure. Cordova Ranger District interpretive specialist Sandy Frost, designed the poster and had them printed on plastic stock. Posters were posted at angler access points along the upper Kenai River (on the National Forest and the Kenai National Wildlife Refuge), Quartz Creek, Russian River, the Anchor River on the lower Kenai Peninsula, and fishing tackle outlets. 


\section{The Project}

\section{Moose Creek Fish Viewing Platform SEWARD RANGER DISTRICT}

The Partners

Their Contributions

Seward Boy Scouts (In-kind) $\$ 5,000$

\section{The Benefits}

- one viewing platform

\section{The Work}

Eagle Scout Dan Butts designed and coordinated the construction of the salmon viewing at Moose Creek. The troop removed the old structure and completely built the new deck.
This platform is on a creek which parallels the Seward Highway Scenic Byway and is a popular stop for the tourists to view red salmon which spawn in the creek. 


\title{
The Project
}

\section{Fisheries Habitat Mitigation ON \\ Highway RealignMent PROJECTS \\ SEWARD RANGER DISTRICT}

\section{The Partners}

Their Contributions

\author{
Alaska Department of Fish and Game-Habitat Division \\ (salary) $\$ 600$ \\ Alaska Department of Transportation. \\ (salary) $\$ 600$ \\ Federal Highways Administration \\ (salary) $\$ 600$ \\ U.S. Fish and Wildlife Service - Ecological Services \\ (salary) $\$ 600$ \\ University of Alaska - Environmental and \\ Natural Resources Institute.... \\ (salary) $\$ 3,000$
}

\section{The Benefits}

- developing fisheries mitigation projects associated with highway construction

\section{The Work}

The district fisheries staff worked with the cooperating agencies in developing fisheries habitat mitigation plans associated with highway realignments on the Seward Highway and Exit Glacier Road. Mitigation on the Seward Highway realignment included designing two diversion channels to replace habitat lost from realigning the highway. The Forest Service and cooperating agencies provided valuable input to Alaska Department of Transportation (ADOT), which required the contractor to install instream habitat structures, and placement of alder brush mattressing along the diversion channels to increase margin habitat and reduce erosion.

The Forest Service was the lead agency in developing the mitigation plan for realignment of 7 miles of the Exit Glacier Road. Both on site and off site fisheries mitigation projects were incorporated into the contractors specifications. Mitigation projects will include deepening and placement of large woody debris in a slough to Resurrection River, placement of structures and revegetating along an existing rearing pond network, and excavation of rearing ponds along the road right-a-way. 


\title{
The Project
}

\author{
KENAITZE INDIAN TRIBE INTERPRETIVE SITE \\ LOCATION: MILEPOST 54.5 STERLING \\ HIGHWAY, COOPER LANDING \\ SEWARD RANGER DISTRICT
}

\section{The Partners}

Their Contributions

Kenaitze Indian Tribe

$\$ 53,000$

Chugach National Forest

$\$ 118,000$

\section{The Benefits}

- protecting cultural features on the Kenai Peninsula

- instilling an appreciation among visitors to the Kenai Peninsula for the heritage represented by cultural features, as well as for the culture and activities of today's Kenaitze Tribe

- learning more about the cultural heritage of the Kenaitze people as a source for

developing pride and self-esteem among members of the tribe

- fostering economic well-being by creating new jobs, encouraging Kenaitze youth to pursue education, and exploring employment for the Kenaitze people in the Forest Service

- fish habitat is protected through protection of the streambank. Kenaitze Indian Tribe Members and the taxpaying public benefit through saving cultural resources from further damage.

\section{The Work}

During the summer of 1991, the Forest Service noticed that a Dena'ina archaeological site within the Sqilantnu Archaeological District adjacent to the Kenai River was being overused and abused by people during salmon runs on the Kenai and Russian Rivers. People were using Dena'ina house pits as toilets and trash dumps. They were driving and camping on archaeological features. Foot traffic was eroding the streambank and uncovering midden sites.

In the spring of 1992, parts of the area were blocked off to vehicle traffic, and the entire area was closed to camping, campfires, and boat launching. The Kenaitze Indian Tribe, based in Kenai, offered to provide tribal members to help the Forest Service enforce the closures.
Staff and volunteers from the Kenaitze Indian Tribe, staffed the site seven days a week from early June through Labor Day. They interpreted archaeological features to the public and explained the reasons for the special regulations.

Over 100 people attended the Grand Opening for the Kenaitze "Beginnings" Interpretive Site, held on June 25, 1993. Tribal Chairperson Clare Swan, opened the ceremony. All in attendance participated in a friendship circle. The circle was made out of quilt pieces. All circled around the friendship circle, while words of friendship and commitment were spoken. At the closing of the friendship circle, all took away with them a piece of the friendship circle, to symbolize the friendship among the Kenaitze Indian Tribe, the U.S. Forest Service and all those present at the ceremony. 
The Kenaitze Jabil'ina Dancers performed a Dena'ina Welcome Dance. Tribal member Bunny Swan sang songs she had written and composed, titled "Being Whole", "Where are the Drums" and "If the Rivers Run Dry".

Deputy Regional Forester Bob Williams, Chugach Forest Supervisor Bruce Van Zee, Seward District Ranger Duane Harp, and Seward Recreation Staff Officer Deidre St. Louis, spoke on behalf of the U.S. Forest Service. Regional Assistant Director of Recreation, Cultural Resources and Wilderness Resource, Paul Brewster, were also in attendance.

In 1993, Kenaitze interpreters contacted over 1,000 visitors, conducted guided walks and monitored visitor compliance of the posted rules (no camping, no boat launching, and no fires).

Kenaitze Interpreters participated in a Forest Service program for fifth grade students called "Environmental Awareness Days". Kenaitze Interpreters demonstrated to the fifth graders how sap was used from trees and how arrowheads an blades were sharpened by Kenaitze ancestors.

Brochures for self-guided tours were designed, produced and made available to visitors in brochure boxes along the nature trail.

Kenaitze Youth Camp: Kenaitze Youth attended a three week youth camp. Campers participated in trail construction, revegetation projects, archaeological surveys, sign installation, streambank stabilization, bench construction, wildlife management, and fire fighting familiarization.

Kenai and Russian Rivers Confluence Closure: The triangle shaped piece of land where the Kenai River and Russian River flow together was closed to foot traffic. The purpose of the closure was to protect streambanks, vegetation, and cultural resources. The closure allowed vegetation to re-establish in an area highly impacted by fishermen, slowed erosion of the streambank, and protected archaeological features from deteriorating further.

During the 1992-1993 winter, Forest Service personnel specialists and a professional forester hosted a workshop for Kenaitze tribal members during the winter. The purpose of the workshop was to explain the benefits of working for the Forest Service and how to fill out an SF-171 application for Forest Service Jobs.

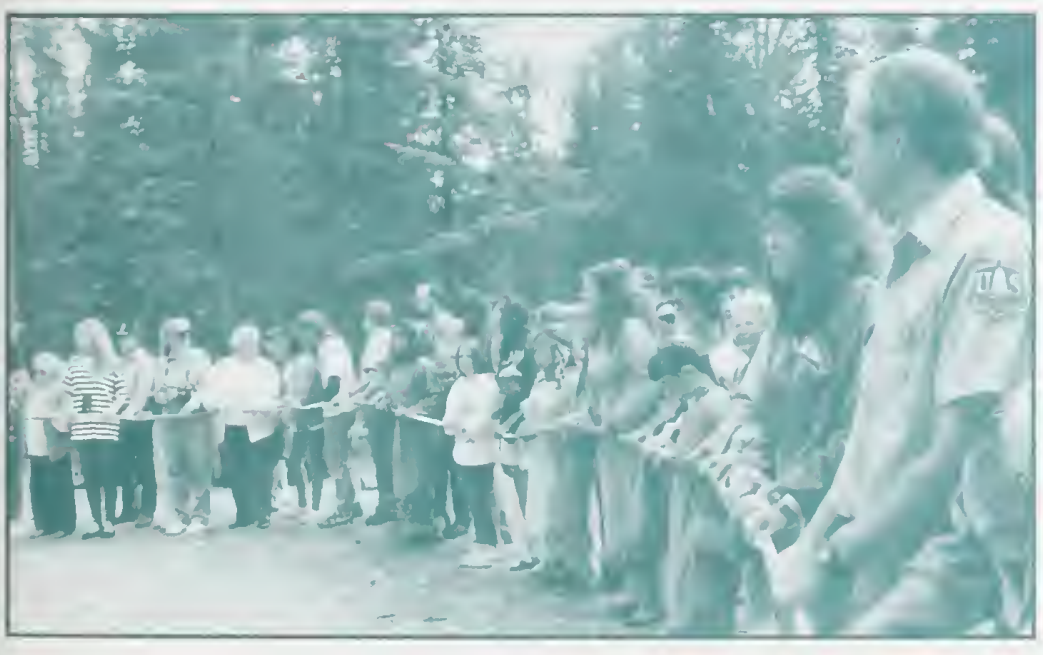

Friendship circle at opening ceremony for Kenaitze Indian Tribe Interpretive Site 


\section{The Project}

\section{Providing Public Sweet Smelling Toilet SEWARD RANGER DISTRICT}

State of Alaska - Division of Parks and Outdoor Recreation ......\$200 in labor and State land for toilet $\$ 1,000$ per year Chugach National Forest ............................................SST \$10,000, Labor $\$ 400$ Kenai National Wildlife Refuge.....(provided equipment for installation) $\$ 800$

The Benefits

- provide needed facility for visitors to Kenai Peninsula

- reduce health and sanitation problems at other pull-outs along Sterling

Highway that were being used as rest areas

\section{The Work}

The Seward Ranger District loaned a Sweet Smelling Toilet to the state which was installed on state land in the Cooper Landing area. The state provided labor, the U.S. Fish and Wildlife Service provided equipment, and the Forest
Service provided labor.

The Forest Service will maintain the toilet under a construction agreement with the state in 1994. 


\section{The Project}

\section{WORLD EXPLORER CRUISES \\ SEWARD RaNGER DISTRICT}

\section{The Partners}

Their Contributions

World Explorer Cruises $\$ 600$

Chugach National Forest $\$ 800$

\section{The Benefits}

- 100 visitors experienced botanical walks

\section{The Work}

Through an agreement with World Explorer Cruises (WEC), Seward Ranger District interpretive specialist, Katy Toth-Stauble, led six 1-hour botanical walks for cruise ship passengers. The cruise ship docked eight times in Seward in 1993.
Participants ranged in age from 50-60 years old. Hikes took place on the Resurrection River Trail and focused on plant identification, traditional and modern uses of plants, and the natural history of the area. 


\section{The Project}

\section{"CONNECTIONS" - A MUSEUM EXHIBIT \\ CORDOVA RANGer DisTRICT}

Chugach National Forest ....................................................................................\$4,300

Cordova Historical Society ..............................................................................\$2,500

City of Cordova ............................................................................................\$1,000

Cordova Historical Museum........................................................(In-kind) \$1,500

\section{The Benefits}

- the "Connections" exhibit in the corridor between the Cordova Library and the museum - an educational tool to provide information about the historical and continuing ties between Russia and Alaska

\section{The Work}

In 1993, the Cordova Ranger District entered into a challenge cost-share agreement with the Cordova Historical Society to develop an educational exhibit explaining the cultural links between the Chugach National Forest, the community of Cordova, and Russia. This successful exhibit highlights the connections between the people of Alaska and Russia, and chronicles Cordova's 1991 Russia-America 250 celebration.
The Cordova Historical Museum contracted a private exhibit planner to design the "Connections" exhibit. The Cordova Ranger District provided the supplies and personnel to build the exhibit.

Developed through the efforts of a coalition of partners, the "Connections" exhibit echoes the cultural ties that were resurfaced and strengthened during the 1991 celebrations. 


\section{The Project}

\section{Watchable Wildlife Placemats \\ CORDOVa RANGER DISTRICT}

The Partners

Their Contributions

Alaska Department of Fish and Game

$\$ 1,000$

Prince William Sound Community College (In-kind) $\$ 300$

Chugach National Forest $\$ 1,500$

\section{The Benefits}

- design and printing of 5,000 full color watchable wildlife placemats to be distributed to restaurants in Cordova

\section{The Work}

One way to educate the public about the fish and wildlife resources of the Copper River Delta is to provide information through local businesses. One innovative approach was the creation of watchable wildlife placemat for Cordova restaurants.

The placemat depicts the Copper River Highway from Cordova to the Million Dollar Bridge. Along the 50-mile stretch of road, several spots are highlighted for watchable wildlife such as shorebirds, dusky Canada geese, brown bear, moose, bald eagle, salmon, and mountain goat. A key on the placemat describes each of these species to the reader.
The Cordova Ranger District developed the design and camera-ready artwork for the project. The Alaska Department of Fish and Game funded the printing and distribution of the placemat.

The placemats were distributed to area businesses in early summer 1993 . Visitors greatly appreciated the informative and attractive publication and the town's supply quickly was exhausted.

The Cordova Ranger District and the Alaska Department of Fish and Game are pursuing opportunities to reprint the Watchable Wildlife placemat. 


\section{The Project}

\section{Transport Cabin MaInTenanCE Materials on ResurRection Pass TraIL \\ SEWARD RANGER DISTRICT}

The Partners

Their Contributions

Moose Pass Dog Musher Dave Lindquist

and two Dog Teams

(In-kind) $\$ 500$

Seward Dog Musher Mitch Seavey and Dog Team

(In-kind) $\$ 350$

Chugach National Forest (salary and cabin) $\$ 166$

\section{The Benefits}

- transported $\mathbf{4 5 0}$ pounds of materials into remote recreation cabins - saved cost of nights into those lakes

- materials used to improve condition of cabins

\section{The Work}

Hauled cabin maintenance and construction materials to cabins on Resurrection Pass Trail by dog sled April 9 and 10, 1993.

Purpose: To get materials to the cabins which we were not able to haul in by snowmobile because of the closures after February 15 to motorized vehicles on Resurrection Pass Trail.
Lumber for outhouse shoring was taken to Trout Lake and Swan Lake cabins. Lumber for steps to Trout Lake cabin. Miscellaneous (maul, extinguisher, saw blades, etc.), garbage hauled out. Lime for outhouses, visitor register pages.

Total weight of all materials taken was approximately 450 pounds. 


\section{The Project}

\section{Watchable Wildlife Radio Series CORdOVA RANGer DISTRICT}

\section{The Partners}

\section{Their Contributions}

KLAM Radio

Whiskey Ridge Trading Post

Chugach National Forest $\$ 2,000$

\section{The Benefits}

- production of 24 radio scripts with the potential of reaching 1,900 Cordovans weekly (aired twice each week)

\section{The Work}

KLAM Radio listeners heard a new

"Watchable Wildlife Update" every week from June through September. Each program provided a blend of natural history and national forest management information.

The Cordova Ranger District researches, writes, and recorđs each program. KLAM Radio engineers handle the production, broadcast, and advertisement. Whiskey Ridge Trading Post of Cordova offered to sponsor the show paying for KLAM's air time.

KLAM received many calls from Cordovans praising the show. Since 1991, its broadcasts have been increased to twice weekly. The Cordova Ranger District plans to continue this popular public service program in 1994.

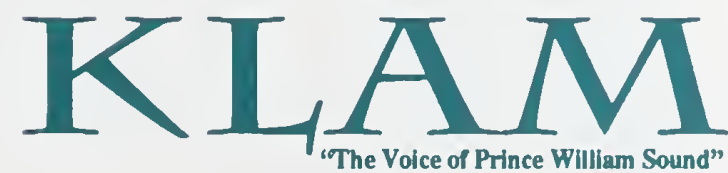

1450 AM

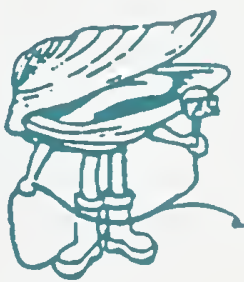




\section{The Project}

\section{Copper River Delta Shorebird Festival CORDOVa RaNGER DISTRICT \\ AND COPPER River DELTA INSTITUTE}

\section{The Partners}

Their Contributions

Copper River Delta Institute

(In-kind) $\$ 3,000$

Cordova Chamber of Commerce In-kind

University of Alaska-Fairbanks (In-kind) $\$ 1,500$

Alaska Department of Fish and Game In-kind

Prince William Sound Science Center (In-kind) $\$ 1,000$

Prince William Sound Community College (In-kind) $\$ 2,000$

Cordova Public Schools In-kind

U.S. Fish and Wildlife Service In-kind Anchorage Audubon Society In-kind

Bidarki Recreation Center In-kind

Chugach National Forest $\$ 4,000$

The Cordova Times In-kind

British Petroleum In-kind

USDA Forest Service, Rural Development $\$ 8,000$

Kelly Weaverling and Susan Ogle In-kind Wrangell/St. Elias National Park and Preserve In-kind

\section{The Benefits}

- more than 150 birders participated in the $\mathbf{1 0}$ day workshop

- 400 KEDs (kid environmental days)

\section{The Work}

In May 1990, the Copper River Delta was designed a Hemispheric Site in the Western

Hemisphere Shorebird Reserve Network (WHSRN). This network identifies vital shorebird habitats throughout the western hemisphere and strives to provide for their protection. The Chugach Alaska Corporation, Eyak Corporation, City of Cordova, USDA Forest Service, Alaska Department of Fish \& Game, and the U.S. Fish \& Wildlife Service formed a coalition of private landowners and public land managers to co-sign this important designation.
As part of the WHSRN dedication celebrations, the Copper River Delta Institute, in partnership with the Cordova Ranger District, conducted the first Copper River Delta Shorebird Workshop. The goal of this first effort was to educate and excite Cordovans about the area's remarkable shorebird resource.

From these modest beginnings, the Copper River Delta Shorebird Festival has grown into a watchable wildlife event of national significance. In 1992, bird watchers and nature enthusiasts filled every hotel and bed \& 
breakfast room in Cordova. Participants contributed an estimated $\$ 30,000$ to the local economy at time when cash reserves were at their lowert levels. Representative from the Anchorage Chapter of the Audubon Society reported that the Shorebird Festival was one of the largest gatherings of recreational bird watchers ever assembled in Alaska.

During the 1993 festival, bird watchers will have the opportunity to participate in a wide range of educational and community events. In addition to numerous filed trips to view shorebirds and waterfowl, children's activities, educational seminars, an art show, a community dinner and dance, and an evening dinner cruise will be offered. The Shorebird Festival offers something for everyone!

The success of the Copper River Delta Shorebird Festival is spreading. In 1993, the U.S. Fish and Wildlife Service in Homer, Alaska is organizing a similar shorebird festival. Communities throughout the state are following Cordova's lead and recognizing the economic benefits of developing unique ecotourism opportunities in partnership with land managers.

The Copper River Delta Shorebird Festival has received wide media coverage. The local newspaper and radio station provide extensive coverage of the festival and the shorebird migration. Regional newspapers and radio stations also run stories about the event. In 1992, an Anchorage TV station produced a 30minute program about the workshop and birding opportunities on the Copper River Delta. Also, CNN and Alaska Magazine provided national coverage on the shorebirds and shorebird research. Footage of the shorebird migration was used in Charles Kuralt's Sunday program and the shorebird festival was even mentioned in the popular TV sitcom Northern Exposures! The partners involved in the Shorebird Festival continue to work with local, regional, and national media representatives to help bring this unique spectacle to citizens not able to travel to this isolated community.

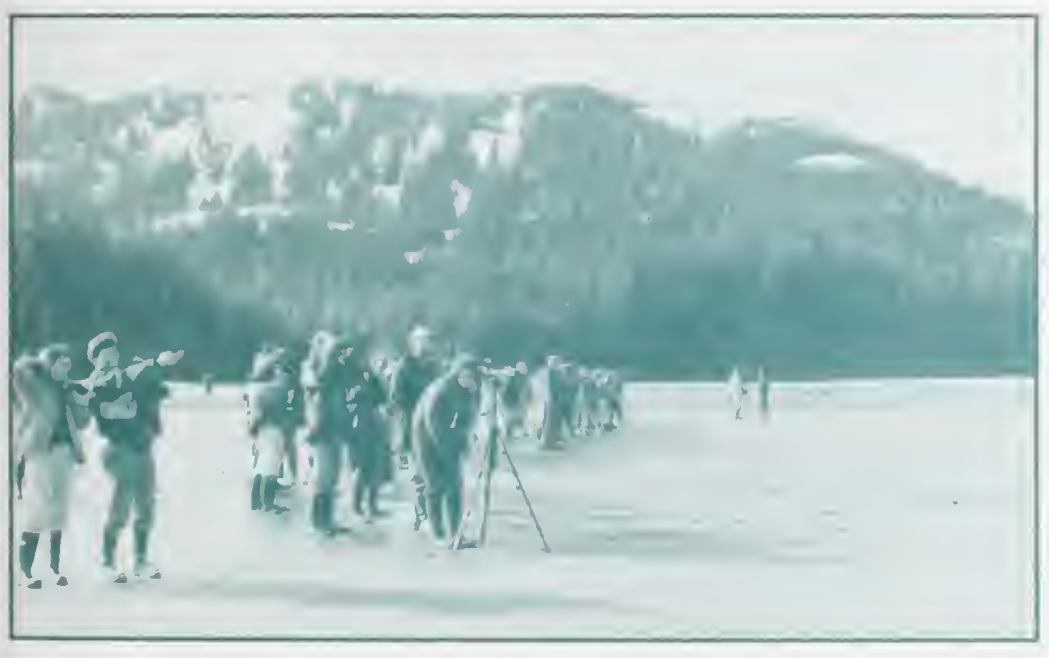

Enthusiastic birders spot western sandpipers and dunlins during Cordova's Shorebird Festival. 


\title{
The Project
}

\section{Copper River Delta Media Projects \\ CORDOVA RANGER DISTRICT}

Their Contributions

The Cordova Times In-kind

Prince William Sound Community College ................................................ In-kind Alaska Department of Fish and Game .......................................................... In-kind Chugach National Forest ....................................................................................\$3,000 Copper River Delta Institute .............................................................................\$2,000

\section{The Benefits}

\author{
- 15 articles in the Cordova Times \\ - one feature article in Alaska Magazine \\ - one feature article in ADF\&G's Alaska's Wildlife \\ - one 30-minute "Assignment Alaska" TV program \\ - photographs included in numerous agency publications
}

\section{The Work}

During 1992, The Cordova Times carried an

The Cordova Ranger District and the Chugach National Forest have long been active in wildlife and fisheries management on the Copper River Delta and in Prince William Sound. Yet few Cordovans are aware of the range of projects that are initiated and coordinated by the district. In an attempt to educate the local public and gather input into the district's programs, an aggressive public education program was initiated in 1991 and continued in 1992. The district was effective at publishing feature articles in the local newspaper, The Cordova Times. article covering a district event or program 15 of 20 weeks. The articles were either written by newspaper staff or district personnel. The development of black and white photo file was given high priority.

The district coordinated the production of a 30-minute "Assignment Alaska" program on KTUU television in Anchorage. This program highlighted the spectacular shorebird migration and the dusky Canada goose nest island project. The program aired in mid-May. 


\section{The Project}

\section{A WORKSHOP ON CRITICAL FOREST HABITATS AND \\ Long-Term PlanNing IN THE \\ Prince William Sound AREa \\ COPPER RIVER DELTA INSTITUTE}

\section{The Benefits}

- forest habitat workshop in Cordova, Alaska, November 1992

- published proceedings

\section{The Work}

The main objective of this workshop was to examine the dependence of fish, wildlife, and human activities on the rain forests of Prince William Sound. This issue is relevant because of the increasing dependence of the local communities on timber, fish, and wildlife resources as oil revenues decline. The potential availability of funds from the Exxon Valdez oil spill settlement expand the option for timber management and long-range planning in the region.
The objectives of the workshop were to define, identify, and map critical rain forest habitats; examine silvicultural alternatives and alternative methods for timber harvest; recommend future research and monitoring; propose long term plans to sustain natural resources; and publish proceedings and invited papers. Participants included scientific, public, private, and Native community representatives. 


\section{The Project}

\section{Forest InTERPReters Staff The M/V PTARMigan on Portage LaKe GlaCiER RANGer DisTrict}

Westours $\$ 10,800$

Chugach National Forest In-kind

\section{The Benefits}

- interpreters presented a 1-hour interpretive talks to visitors

- over 31,000 passengers were contacted by uniformed Forest Service employees and volunteers

\section{The Work}

Programs about the natural and cultural history of Portage Glacier and the Glacier Ranger District of the Chugach National Forest were presented to passengers aboard the $\mathrm{M} / \mathrm{V}$
Ptarmigan on Portage Lake. The M/V Ptarmigan was staffed on each trip (six per day) for the 1-hour tour. 


\title{
The Project
}

\author{
FOREST INTERPRETERS STAFF AlASKA MARINE \\ HighWAy SySTEM FERRIES IN PRINCE WILliam SOUND \\ GLACIER RANGER DISTRICT
}

The Partners

Their Contributions

\begin{abstract}
Alaska Department of Transportation
Alaska Marine Highway System ................................................................\$1,500

Chugach National Forest ...................................................................................... In-kind
\end{abstract}

\section{The Benefits}

- visitors were contacted by uniformed Forest Service employees and volunteers

- 150 interpretive programs were presented to the public

\section{The Work}

During the 1993 season, Glacier Ranger

District interpreters staffed and gave programs on the M/V Tustumena 2-day trip from Seward to Valdez and return, as well as manning four 2-day round trips on the $M / V$ Bartlett from Whittier to Valdez to Cordova and retum to Whittier. Thousands of visitors disembarked from these vessels with a greater understanding of Alaska, the wildlife and pristine wildemess of the Chugach National Forest. Forest interpreters presented an introduction to the Chugach National Forest, talks on Columbia Glacier, as well as other topics. 


\section{The Project}

\section{Prince William Sound Tourism ASSOCiation \\ GLACIER RANGER DISTRICT}

\section{The Partners}

Their Contributions

Prince William Sound Tourism Association ..................................................In-kind

Portage Railroad Station ........................................................................................ In-kind

\section{The Benefits}

- spread the word about Chugach National Forest recreational opportunities along the Seward Highway Scenic Byway and Prince William Sound

\section{The Work}

The Prince William Sound Tourism Association operates a small information center at the new Portage Railroad station. The Glacier Ranger District assisted with this effort by providing brochures and information for them to disperse. The Glacier Ranger District hopes to add to this partnership effort this year by having the Begich, Boggs Visitor Center interpreters help staff the room for several hours each day (during peak use periods). 


\section{The Project}

\section{Chugach State Park \\ Glacier Ranger District}

\section{The Partners}

Their Contributions

Chugach State Park

In-kind

Glacier Ranger District In-kind

\section{The Benefits}

- received several cases of Turnagain Arm brochures

\section{The Work}

The Glacier Ranger District (GRD), worked cooperatively with their neighbors to the north by exchanging brochures. Glacier Ranger District provided several cases of Portage Valley, Born of Ice, Hooked on Fishing, and Seward Highway Scenic Byway brochures to the Chugach State Park Headquarters at
Potters Marsh. They in turn gave the GRD a case of their Turnagain Arm trail brochures. Many of the visitors to the GRD office are heading north on the Seward Highway, the State Park brochure details much of this area, especially the hiking opportunities along this route back to Anchorage. 


\section{The Project}

\section{Alaska Natural History Assocation GLACIER RANGER DISTRICT}

The Partners

Their Contributions

Alaska Natural History Association ............................................................\$65,000

Chugach National Forest ......................................................................................... In-kind

\section{The Benefits}

- interpretive and educational materials, representing the themes of the

Chugach National Forest, were made available to the public

- funds were made available for use in interpretive efforts on

the Glacier Ranger District

\section{The Work}

The Alaska Natural History Association (ANHA), in cooperation with the Glacier Ranger District, operates two ANHA sales outlets, one at the District Office and one at the Begich, Boggs Visitor Center. A portion of the proceeds from these outlets are contributed to the District's Interpretive Program. During FY 1993, \$65,565 was made available to fund Student Conservation Association volunteers, interpretive supplies, copies of "Voices from the Ice", as well as a variety of other items related to the District's interpretive efforts. 


\section{The Project}

\section{Six STUDENT CONSERVATION ASSOCIATION \\ VOLUNTEERS HIRED AS FOREST INTERPRETERS \\ GLACIER RANGER DISTRICT}

The Partners

Their Contributions

Student Conservation Association (SCA) - Program Management......\$4,000

Alaska Natural History Association

$\$ 11,000$

Chugach National Forest

(In-kind) $\$ 1,500$

\section{The Benefits}

- quality public television programs

- local community Forest Service exposure

\section{The Work}

Student Conservation Association volunteers assisted the Forest Service by staffing and presenting interpretive programs at the Begich, Boggs Visitor Center, on Alaska Marine Highway System ferries in Prince William Sound, and on the M/V Ptarmigan on Portage
Lake. Student Conservation Association volunteers also presented interpretive programs at the Williwaw Campground and led walks and talks on the natural and cultural history of Portage Valley and the Chugach National Forest. 
MINERALS, VEGETATION, AND OTHER

PARTNERSHIPS 


\section{The Project}

\section{The Role of EQuisetum in Phosphorous CyCling AND Net Primary Productivity on the Copper River Delta COPPER River DELTA INSTITUTE}

The Partners

Their Contributions

Copper River Delta Institute In-kind

Yale University $\$ 5,000$

Mellon Foundation $\$ 30,000$

\section{The Benefits}

- habitat evaluation

\section{The Work}

In cooperation with Yale University, the Copper River Delta Institute is researching the role if Equisetum in the Copper River Delta's shrub community. A phosphorus budget will be completed to determine if Equisetum acts as a phosphorous pump for the shrub community by absorbing phosphate from the deep mineral soil and translocating it to above and below ground tissues. Inorganic phosphorous released from Equisetum detritus may help support other species in the shrub community including Myrica gale (sweetgale), the primary nitrogen-fixing member of the community and willow, the dominant shrub.

In its third year, this project will be completed in 1994. 


\section{The Project}

\section{The Role Of Nitrogen FiXATION IN \\ COPPER RIVER DELTA ECOSYSTEMS \\ COPPER RIVER DELTA INSTITUTE}

\section{The Partners}

Their Contributions

Copper River Delta Institute In-kind

Pacific Northwest Research Station $\$ 5,000$

Yale University $\$ 5,000$

A.W. Mellon Foundation $\$ 15,000$

\section{The Benefits}

- ecosystem evaluation

\section{The Work}

Since 1989, this study has been testing the hypothesis that biological nitrogen fixation by Myrica gale, nodulated by Frankia sp., is the major source of plant-available nitrogen in the myrica-willow shrub community of the delta.
This study is collecting data on the above-andbelow ground biomass production, biological nitrogen fixation and photosynthesis and respiration rates in myrica, willow and their associates. 


\section{The Project}

\section{Modeling Primary Productivity in the COPPER RIVER DELTA ECOSYSTEM \\ COPPER RIVER DELTA INSTITUTE}

\section{The Partners}

Their Contributions

Copper River Delta Institue .............................................................................In-kind

Pacific Northwest Research Station .....................................................\$5,000

Yale University .........................................................................................5,000

A.W. Mellon Foundation .....................................................................................\$15,000

\section{The Benefits}

- ecosystem evaluation

\section{The Work}

A model of productivity in the Delta is being developed to test the ecosystem fit hypothesis. This hypothesis states that the degree of fit of an existing array of plants to its current environment is best described by the ratio of actual net primary production to the theoreti- cal maximum net primary production for that location. Ultimately this work will allow us to predict the sustainability of various arrays when subjected to specific management practices. 


\title{
The Project
}

\author{
ASSESSING The DYNAMICS OF NATURAL RESOURCE \\ Development in Prince William Sound \\ COPPER River DELTA INSTITUTE
}

The Partners

Their Contributions

Copper River Delta Institute $\$ 5,000$

Pacific Northwest Research Station $\$ 15,000$

\section{The Benefits}

- economic analysis of natural resources

\section{The Work}

The coastal temperate rainforest of Greater Prince William Sound (PWS) is a complex natural resource ecosystem with conflict over its future. There is a need to assess the dynamics of resource development in an attempt to minimize conflict and allow equitable allocation of resources and benefits to PWS constituents. A methodical economic analysis will be used to account for multiple geographic scales and lay out the interaction and linkages of forest sector development with other resources. The impacts of several timber development scenarios on the production of other key resources and values (anadromous fish, game species, tourism and recreation, and subsistence opportunities) will be assessed. Resulting employment and the amount and distribution of income within PWS will also be estimated. Policy instruments and alternative opportunities that provide incentives for all landowners to manage forest lands for multiple resource benefits and uphold equitable distribution of the benefits from economic development to residents of the region will be assessed for effectiveness. 


\section{The Project}

\section{Ecological Classification and Mapping of THE COPPER RIVER DELTA CORdOVA RANGer DISTRICT}

Ducks Unlimited, Inc. $\$ 17,060$

Copper River Delta Institute $\$ 5,000$

Chugach National Forest $\$ 50,000$

\section{The Benefits}

- obtain a repeatable wetland vegetation classification map based on satellite imagery which can be used to spatially monitor vegetation changes over time on the Copper River Delta.

\section{The Work}

As a result of the 1964 uplift the vegetation successional trends on the Copper River Delta are changing from a partial tidal influenced wetlands to a freshwater wetland shrub complex. This rapid vegetation change has led to a significant change in wildlife populations and distributions across the delta.

Ducks Unlimited Inc. (DU) and the Copper River Delta Institute are cooperating with the Chugach National Forest in obtaining a repeatable wetland vegetation classification map based on satellite imagery which can be used to spatially monitor vegetation changes over time. Field work accomplished in 1993 includes the collection of 450 plots using helicopter and visual estimations of percent cover to ground truth or "train" the satellite image. ERDAS format and ARC/INFO GRID rastor files are being produced by DU which will integrate into the Forest GIS database. 


\title{
The Project
}

\section{Wetland Vegetation Classification of The COPPER RIVER DELTA \\ CORDOVA RANGer DiSTRICT}

\section{The Partners}

Their Contributions

\author{
Nature Conservancy-Alaska Natural Heritage Program ........................\$53,190 \\ Chugach National Forest \\ $\$ 81,300$
}

\section{The Benefits}

- classification of wetland plant communities of the Copper River Delta

\section{The Work}

The primary purpose of vegetation classification is to provide resource management with an understanding of the plant communities and their successional pathways for management interpretations. This 3-year study describes the present plant communities, their successional pathways, and the affects natural geometric processes have on them. The vegetation on the Copper River Delta is continually changing as a result of succession, tectonic uplift, land erosion, and deposition of sediments along river and tide channels. Of special concern are the massive changes in vegetation initiated by the 1964 earthquake, which uplifted the delta 612 feet. These vegetation changes in turn have strongly affected such management concerns as nesting habitat for dusky Canada geese, staging ground for shorebirds, and the delta's moose population.
During the 1993 field season, reconnaissance information and data from 140 plots on the western half of the Copper River Delta were collected. These data and wetland plot data from the Cordova Ranger District will be used to develop a preliminary classification of wetland community types for the Chugach National Forest. The classification will be continually refined and updated through 1995 as additional information is reviewed and data is collected.

For the Alaska Natural Heritage Program, the classification will help refine and add to its database of rare, unique, and unusual plant communities. For the Chugach National Forest, it will add to the database for development of a comprehensive plant classification. 


\title{
The Project
}

\author{
RUTGERS UNIVERSITY STUDY TRIP \\ CORDOVA AND SEWARd RANGER DISTRICTS
}

\section{The Partners}

Their Contributions

Rutgers University ............................................................................................. In-kind

Chugach National Forest Logistical support

\section{The Benefits}

- primary school environmental education curriculum

- interpretive plan for the Russian River area

\section{The Work}

In August 1993, 20 students from Rutgers University in New Jersey visited the Seward Ranger District and the Copper River Delta for a one-week study trip. Students met with civic leaders and Cordova Ranger District staff to leam about the natural and cultural history of the Copper River Delta and the issues facing the Cordova community and the region.

The Cordova Ranger District coordinated the group's stay in Cordova and provided lodging and logistical support during their visit. The team of university students com- pleted the development of primary school environmental education curricula.

While stationed on the Seward Ranger District, Rutgers students studied resource management. They began special studies projects addressing such subjects as bear education and Russian River streambank erosion interpretation.

Coordinated by Dr. Roger Locandro of Rutgers University, the field study program attempts "to combine basic science and social science to focus on the individual interests of the students in the class." 


\title{
The Project
}

\author{
SOUTHERN ZONE LOGISTICS OFFICE \\ Chugach National Forest, Fire and A viation
}

State Division of Forestry .........................................................................................In-kind Chugach National Forest In-kind

\section{The Benefits}

- interagency logistics and dispatch support

\section{The Work}

Since 1991, the Alaska Division of Forestry and the Chugach National Forest have operated a jointly staffed logistics and dispatch center in Southcentral Alaska. This center is the nerve center for logistics and aviation dispatching for both agencies. The partnership has allowed the agencies to pool resources into a highly efficient intergrated dispatch office which is operated at a reduced cost to both agencies. During 1993, the Southem Zone Logistics Office played an important role in the mobilization and movement of critical fire suppression resources to fire operations throughout the Southcentral and Southwestern parts of Alaska. 


\title{
The Project
}

\author{
INTERAGENCY AIRTANKER \\ Chugach National Forest, Fire and Aviation
}

The Partners

Their Contributions

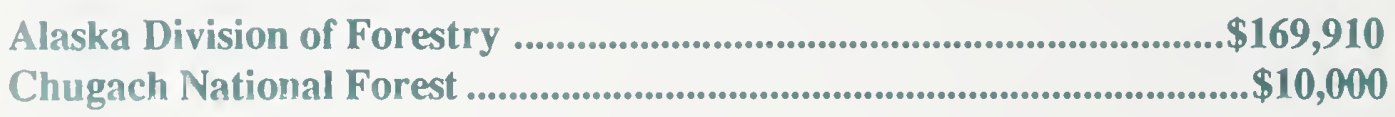

The Benefits

- retardant support for problem fires

The Work

The Chugach National Forest and the Alaska Division of Forestry have pooled resources to jointly contract a DC-4 airtanker. In 1993, this was one of four airtankers stationed in Alaska. Airtankers are an expensive but highly effective part of the arsenal of tools fire fighters use on the most potentially disastrous fires. In 1993, the airtarker was dispatched to fires tiroughout laskn including fires on
Chugach National Forest, State of Alaska, and Bureau of Land Management (BLM) jurisdictions. In 1993, retardant dropped on the Trail Lake fire, burning only 3 miles from the community of Moose Pass Alaska, was credited with slowing the fire sufficiently so that Forest Service, State of Alaska, BLM, and Moose Pass Volunteer Fire Department fire fighters could contain the fire before it reached the community. 


\title{
The Project
}

\author{
KAKM CHANNEL 7 \\ Glacier RANGer District
}

The Partners

Their Contributions

KAKM

In-kind

Chugach National Forest

In-kind

\section{The Benefits}

- quality public television programs

- local community Forest Service exposure

\section{The Work}

The Glacier Ranger District gave generously of their time during the KAKM Channel 7 Public Television Fund Drive, making it possible for the station to continue to show excellent educational and entertainment programs to the residents of Southcentral Alaska.

Each year the Glacier Ranger District joins forces with KAKM by helping with their Channel 7 Public Television Fun 1 ive 


\title{
The Project
}

\author{
INTERAGENCY FIRE HELICOPTER \\ ChugaCh NATIONAL FOREST, Ftre AND AVIaTion
}

\section{The Partners}

\section{Their Contributions}

\author{
Alaska Division of Forestry ...................................................................\$100,440 \\ Chugach National Forest ........................................................................................\$11,160
}

\section{The Benefits}

- highly mobile initial attack capabilities

- cooperative fire suppression assistance between the

Division of Forestry and Forest Service

- reduced cost of operation for both agencies

\section{The Work}

Effective fire suppression requires rapid and aggressive initial attack on new fires while they are still small and manageable. In Alaska, the lack of roads make helicopter operations an essential part of any wildland fire program. Through this partnership, the Chugach National Forest and The Alaska Division of Forestry have pooled funds to jointly contract a Bell 206B helicopter. The helicopter is used as a primary fire fighting tool by both agencies. It has given the partner the capability to rapidly transport fire fighters and equipment to fire emergencies, and has given the fire fighters the necessary edge to keep many fires from growing into large destructive problems.

During periods of low fire danger, the helicopter has also been used for other resource management projects. In 1993, these projects included wildlife habitat improvement, recreation facilities maintenance and communications system repairs.

By sharing the cost of the aircraft, both agencies have been able to reduce operating expenses and accomplish fire and resource work at a reduced cost to the tax payer. 


\section{PARTNERSHIP ProGRAM SUMMARY TABLES}



Project
Partners
Partners'
Forest

\section{Recreation}

\begin{tabular}{|c|c|c|c|}
\hline $\begin{array}{l}\text { Recreation } \\
\text { Opportunities Along } \\
\text { the Seward Highway } \\
\text { Scenic Byway }\end{array}$ & $\begin{array}{l}\text { Cook Inlet Aquaculture } \\
\text { Association (CIAA) } \\
\text { Seward Chamber of } \\
\text { Commerce (SCC) }\end{array}$ & $\begin{array}{l}\$ 3,000 \\
\$ 10,000\end{array}$ & $\$ 8,000$ \\
\hline $\begin{array}{l}\text { Russian River Anlger } \\
\text { Trail "A Plan for } \\
\text { Recovery" }\end{array}$ & $\begin{array}{l}\text { Cook Inlet Region, Inc. } \\
\text { (CIRI) } \\
\text { Kenaitze Indian Tribe } \\
\text { National Marine Fisheries } \\
\text { Service } \\
\text { Alaska Department of Fish } \\
\text { and Game } \\
\text { Alaska State Parks } \\
\text { U.S. Fish and Wildlife } \\
\text { Service } \\
\text { Kenai River Sport Fishing } \\
\text { Association } \\
\text { Alaska Flyfishers } \\
\text { Alaska Sportfishing } \\
\text { Association } \\
\text { Rutgers University } \\
\text { Undergraduate Student }\end{array}$ & $\begin{array}{l}\text { All partners are } \\
\text { providing donated } \\
\text { time- }- \\
\text { approximately six } \\
\text { person days per } \\
\text { partner }\end{array}$ & In-kind \\
\hline National Trails Day & $\begin{array}{l}\text { Arctic Mountain Bike Club } \\
\text { REI } \\
\text { Kenaitze Indian Tribe }\end{array}$ & $\begin{array}{l}\text { (In-kind) } \$ 1,260 \\
\text { (In-kind) } \$ 200 \\
\text { In-kind }\end{array}$ & (salary) $\$ 800$ \\
\hline $\begin{array}{l}\text { Backcountry Trail } \\
\text { Maintenance }\end{array}$ & $\begin{array}{l}\text { Shawn Lyons, Outdoor } \\
\text { writer for Anchorage Daily } \\
\text { News }\end{array}$ & $\begin{array}{l}\text { In-kind (salary) } \\
\$ 500\end{array}$ & In-kind \\
\hline $\begin{array}{l}\text { Cordova International } \\
\text { Volunteer Month }\end{array}$ & $\begin{array}{l}\text { Volunteers for Peace } \\
\text { International Volunteers }\end{array}$ & In-kind & $\$ 18,000$ \\
\hline
\end{tabular}




\section{Project \\ Partners \\ Partners' \\ Forest \\ Contributions \\ Contributions}

\section{Recreation (continued)}

\section{Appalachian Mountain}

Club Service Trips

Appalachian Mountain Club

(In-kind) $\$ 7,040$

$\$ 5,800$

Cordova Community

Work Service

Alaska Court System

40 hours

volunteered

In-kind

Boyscouts - Susitna

Council

Boyscouts - Sustina Council

$\$ 16,000$

$\$ 1,050$

Coghill Trail Update

Sierra Club

(in labor) $\$ 12,000$

$\$ 2,250$

\section{Wildlife}

Cooper Landing Small Mammal Monitoring
Rutgers University

Alaska Department of Fish and Game

Sixty-Thiry North

Foundation for North

American Wild Sheep

Foundation for North

American Wild Sheep

Crescent Mountain Moose/Sheep Habitat Improvement

Sixty-Thirty North

Kenai Fjords National Park

$\$ 2,000$

Alaska Fish Wildlife

Protection

Seward Bear Awareness

Program

$\$ 2,000$
City of Seward

U.S. Fish and Wildlife

Bald Eagle Nesting

Survey
Service
88 hours

volunteered In-kind

$\$ 2,000$

$\$ 2,000$

$\$ 2,000 \quad$ In-kind

(In-kind) $\$ 500$

In-kind

(In-kind) $\$ 500$

In-kind 


\begin{tabular}{llll} 
Project & Partners & $\begin{array}{l}\text { Partners' } \\
\text { Contributions }\end{array}$ & $\begin{array}{l}\text { Forest } \\
\text { Contributions }\end{array}$ \\
\hline Wildlife (continued) & & \\
\hline
\end{tabular}

\begin{tabular}{|c|c|c|c|}
\hline \multirow{3}{*}{$\begin{array}{l}\text { Kenai Peninsula } \\
\text { Cooperative Wolverine } \\
\text { Project }\end{array}$} & $\begin{array}{l}\text { Alaska Department of Fish } \\
\text { and Game }\end{array}$ & $\$ 10,000$ & \multirow[b]{3}{*}{ In-kind } \\
\hline & $\begin{array}{l}\text { Kenai National Wildlife } \\
\text { Refuge }\end{array}$ & $\$ 5,000$ & \\
\hline & Kenai Fjords National Park & $\$ 5,000$ & \\
\hline \multirow{4}{*}{$\begin{array}{l}\text { Kenai Peninsula } \\
\text { Cooperative Brown Bear } \\
\text { Model }\end{array}$} & $\begin{array}{l}\text { Alaska Department of Fish } \\
\text { and Game }\end{array}$ & $\$ 5,000$ & \\
\hline & Kenai National Wildlife & & \\
\hline & Refuge & $\$ 5,000$ & \\
\hline & Kenai Fjords National Park & $\$ 5,000$ & In-kind \\
\hline \multirow[b]{2}{*}{$\begin{array}{l}\text { "Give Moose a Brake" } \\
\text { Cooperative Project }\end{array}$} & $\begin{array}{l}\text { Alaska Department of Fish } \\
\text { and Game }\end{array}$ & (In-kind) $\$ 5,000$ & \\
\hline & $\begin{array}{l}\text { Alaska Department of } \\
\text { Transportation and Public } \\
\text { Facilities }\end{array}$ & (In-kind) $\$ 10,000$ & $\$ 20,000$ \\
\hline & $\begin{array}{l}\text { U.S. Fish and Wildlife } \\
\text { Service }\end{array}$ & (In-kind) $\$ 10,000$ & \\
\hline $\begin{array}{l}\text { Neotropical Bird } \\
\text { Monitoring Project }\end{array}$ & $\begin{array}{l}\text { Alaska Department of Fish } \\
\text { and Game }\end{array}$ & (In-kind) $\$ 2,000$ & $\$ 15,000$ \\
\hline \multirow{2}{*}{$\begin{array}{l}\text { Audubon Christmas Bird } \\
\text { Survey }\end{array}$} & $\begin{array}{l}\text { Audubon Bird Club of } \\
\text { Anchorage }\end{array}$ & (In-kind) $\$ 3,000$ & \\
\hline & Seward Pheonix Log & (In-kind) $\$ 200$ & $\$ 440$ \\
\hline \multirow[b]{2}{*}{$\begin{array}{l}\text { Kachemak Bay Shorebird } \\
\text { Festival }\end{array}$} & $\begin{array}{l}\text { Homer Chamber of } \\
\text { Commerce }\end{array}$ & (In-kind) $\$ 5,000$ & \\
\hline & $\begin{array}{l}\text { U.S. Fish and Wildlife } \\
\text { Service }\end{array}$ & $\$ 5,000$ & $\$ 500$ \\
\hline $\begin{array}{l}\text { Prince William Sound } \\
\text { Mountain Goat Survey }\end{array}$ & $\begin{array}{l}\text { Alaska Department of Fish } \\
\text { and Game }\end{array}$ & $\$ 5,000$ & $\$ 10,000$ \\
\hline
\end{tabular}



Project
Partners

\section{Contributions Contributions}

\section{Wildlife (continued)}

\begin{tabular}{|c|c|c|c|}
\hline $\begin{array}{l}\text { Copper River Delta } \\
\text { Moose Habitat Study }\end{array}$ & $\begin{array}{l}\text { Copper River Delta Institute, } \\
\text { Pacific Northwest Research } \\
\text { Station } \\
\text { University of Idaho }\end{array}$ & $\$ 7,000$ & $\$ 20,000$ \\
\hline $\begin{array}{l}\text { Sitka Black-Tailed Deer } \\
\text { Survey }\end{array}$ & $\begin{array}{l}\text { Alaska Department of Fish } \\
\text { and Game }\end{array}$ & $\$ 8,000$ & $\$ 2,000$ \\
\hline $\begin{array}{l}\text { Dusky Canada Goose } \\
\text { Nest Plot Surveys }\end{array}$ & $\begin{array}{l}\text { U.S. Fish and Wildlife } \\
\text { Service } \\
\text { Alaska Department of Fish } \\
\text { and Game }\end{array}$ & In-kind & $\$ 20,150$ \\
\hline $\begin{array}{l}\text { Bering Lake Trumpeter } \\
\text { Swan Study }\end{array}$ & $\begin{array}{l}\text { Copper River Delta Institute } \\
\text { University of Minnesota }\end{array}$ & $\begin{array}{l}\$ 17,000 \\
\$ 16,000\end{array}$ & $\$ 23,900$ \\
\hline $\begin{array}{l}\text { Evaluation of Body } \\
\text { Indices for Assessing } \\
\text { Nutritional Status of } \\
\text { Moose on the Copper } \\
\text { River Delta }\end{array}$ & $\begin{array}{l}\text { Copper River Delta Institute } \\
\text { University of Idaho } \\
\text { Alaska Department of Fish } \\
\text { and Game }\end{array}$ & $\begin{array}{l}\$ 4,000 \\
\text { In-kind } \\
\text { In-kind }\end{array}$ & In-kind \\
\hline $\begin{array}{l}\text { Population Dynamics of } \\
\text { Gray Wolves on the } \\
\text { Copper River Delta }\end{array}$ & $\begin{array}{l}\text { Copper River Delta Institute } \\
\text { University of Idaho }\end{array}$ & $\begin{array}{l}\$ 25,000 \\
\text { In-kind }\end{array}$ & In-kind \\
\hline $\begin{array}{l}\text { Physiology of Migration } \\
\text { in Western Sandpipers }\end{array}$ & $\begin{array}{l}\text { Copper River Delta Institute } \\
\text { University of Washington } \\
\text { BP Exploration (Alaska Inc.) } \\
\text { Accord Environmental }\end{array}$ & $\begin{array}{l}\$ 1,500 \\
\$ 15,000 \\
\text { In-kind } \\
\text { In-kind }\end{array}$ & In-kind \\
\hline $\begin{array}{l}\text { Migratory Shorebird } \\
\text { Staging on the Copper } \\
\text { River Delta }\end{array}$ & $\begin{array}{l}\text { Copper River Delta Institute } \\
\text { National Fish and Wildlife } \\
\text { Foundation } \\
\text { Exxon Company, USA }\end{array}$ & $\begin{array}{l}\$ 15,000 \\
\$ 15,000\end{array}$ & (In-kind) $\$ 2,500$ \\
\hline
\end{tabular}




\begin{tabular}{|c|c|c|c|}
\hline Project & Partners & $\begin{array}{l}\text { Partners' } \\
\text { Contributions }\end{array}$ & $\begin{array}{l}\text { Forest } \\
\text { Contributions }\end{array}$ \\
\hline \multicolumn{4}{|l|}{ Wildlife (continued) } \\
\hline $\begin{array}{l}\text { Copper River Delta } \\
\text { Aerial Moose Survey }\end{array}$ & $\begin{array}{l}\text { Alaska Department of Fish } \\
\text { and Game }\end{array}$ & $\$ 5,000$ & $\$ 1,000$ \\
\hline $\begin{array}{l}\text { Copper River Waterfowl } \\
\text { Surveys }\end{array}$ & $\begin{array}{l}\text { U.S. Fish and Wildlife } \\
\text { Service }\end{array}$ & $\$ 10,000$ & $\$ 8,000$ \\
\hline $\begin{array}{l}\text { District Inventory and } \\
\text { Monitoring }\end{array}$ & $\begin{array}{l}\text { Cooperative effort between } \\
\text { Cordova Ranger District and } \\
\text { Glacier Ranger District }\end{array}$ & $\begin{array}{l}\$ 5,000 \\
\$ 3,000\end{array}$ & combined $\$ 8,000$ \\
\hline $\begin{array}{l}\text { Neotropical Migratory } \\
\text { Bird Monitoring }\end{array}$ & $\begin{array}{l}\text { U.S. Fish and Wildlife } \\
\text { Service }\end{array}$ & $\$ 3,000$ & $\$ 12,000$ \\
\hline Moose Winter Ecology & $\begin{array}{l}\text { Exxon Company, USA } \\
\text { Alaska Department of Fish } \\
\text { and Game }\end{array}$ & $\begin{array}{l}\$ 15,000 \\
\$ 1,000\end{array}$ & $\$ 7,000$ \\
\hline $\begin{array}{l}\text { Turnagain Arm Marine } \\
\text { Mammal Stranding } \\
\text { Network }\end{array}$ & $\begin{array}{l}\text { National Marine Fisheries } \\
\text { Service }\end{array}$ & In-kind & $\$ 2,000$ \\
\hline \multicolumn{4}{|l|}{ Fisheries } \\
\hline $\begin{array}{l}\text { Twentymile River \& } \\
\text { Placer River } \\
\text { Sportfisheries } \\
\text { Management Plan }\end{array}$ & $\begin{array}{l}\text { Alaska Department of Fish } \\
\text { and Game }\end{array}$ & $\$ 200$ & $\$ 5,000$ \\
\hline & $\begin{array}{l}\text { Alaska Department of Fish \& } \\
\text { Game - Sportsfish } \\
\text { Local Anglers }\end{array}$ & $\begin{array}{l}\$ 20,000 \\
\text { In-kind }\end{array}$ & \\
\hline $\begin{array}{l}\text { Kenai Small Lakes } \\
\text { Resident Sportfish } \\
\text { Development }\end{array}$ & $\begin{array}{l}\text { Knots So Fast } \\
\text { Seavy's Christmas Trees }\end{array}$ & $\begin{array}{l}\$ 200 \\
\$ 300\end{array}$ & $\$ 15,000$ \\
\hline
\end{tabular}




\section{Fisheries (Continued)}

Alaska Department of Fish \&

Game - Habitat Restoration

Division

$\$ 1,000$

Alaska Department of Fish \&

Game - Commercial

Fisheries Division

$\$ 500$

$\$ 55,000$

Alaska Department of Fish and Game

$\$ 4,000$

$\$ 8,000$

Study

Mile 18 Cutthroat - Dolly

Varden Study

Alaska Department of Fish

and Game

$\$ 10,000$

$\$ 121,000$

Alaska Department of Fish and Game

In-kind

Prince William Sound

Aquaculture Corporation

In-kind

$\$ 24,000$ and Monitoring

Aquaculure corporaton

Mile 18 Creek Basin

Wild Habitat Survey and

Coded Wire Tagging

Project

Alaska Department of Fish

and Game

$\$ 12,000$

$\$ 18,000$

Mile 25.25 Spawning

Channel

Alaska Department of Fish

and Game

$\$ 3,000$

$\$ 10,000$

Sheridan Habitat

Alaska Department of Fish

Structures

and Game

In-kind

$\$ 8,500$

American Fisheries

American Fisheries Society

In-kind

Society Coho Salmon

Habitat Workshop

Copper River Delta Institute

In-kind

In-kind 


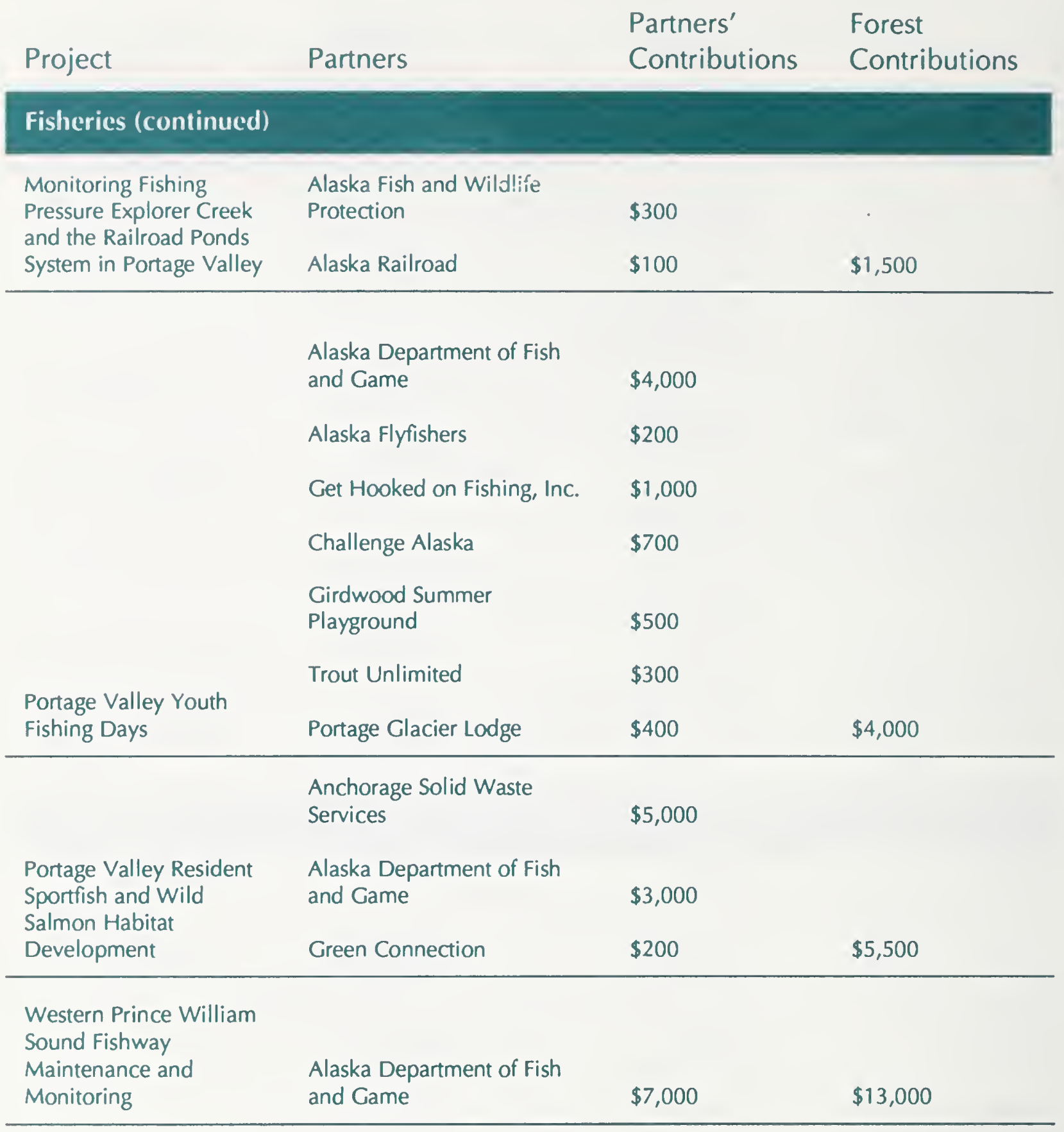




\begin{tabular}{|c|c|c|c|}
\hline Project & Partners & $\begin{array}{l}\text { Partners' } \\
\text { Contributions }\end{array}$ & $\begin{array}{l}\text { Forest } \\
\text { Contributions }\end{array}$ \\
\hline
\end{tabular}

\section{Fisheries (continued)}

Girdwood Communtiy $\$ 1,500$

$\begin{array}{lll}\text { Girdwood Valley Fish } & \begin{array}{l}\text { Alaska Department of Fish } \\ \text { and Game }\end{array} & \$ 500\end{array}$

Coghill Lake

Alaska Department of Fish
and Game

Cooperative Fertilization and Sockeye Salmon Prince William Sound

Enhancement Aquaculture Corporation

Aquaculture Corporation $\$ \$ 500 \quad \$ 64,000$

\section{Natural Resource Conservation Education}

Chugach Region

Elder-Youth Conference Chugachmiut (In-kind) $\$ 20,511 \quad \$ 23,546$

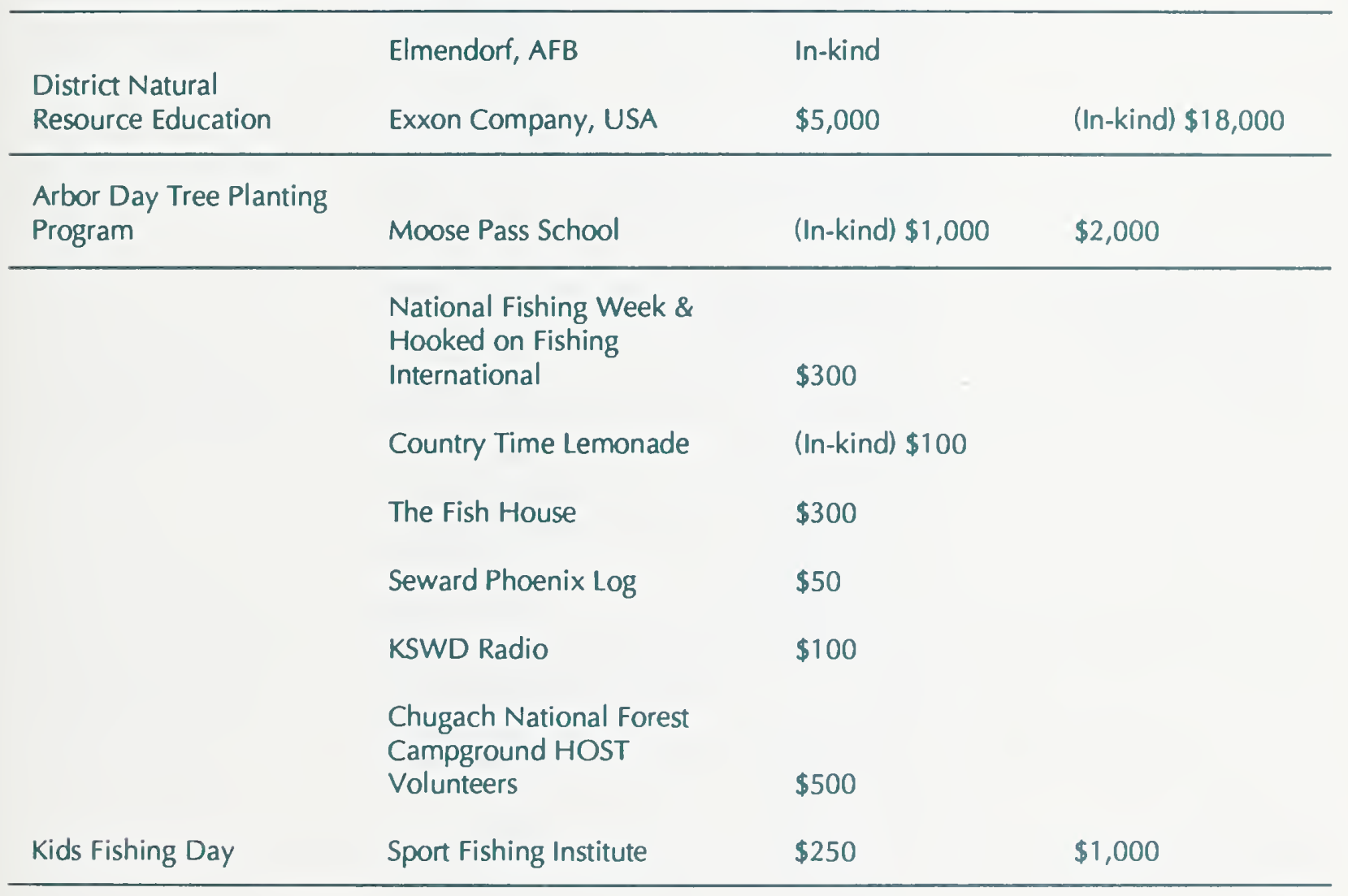




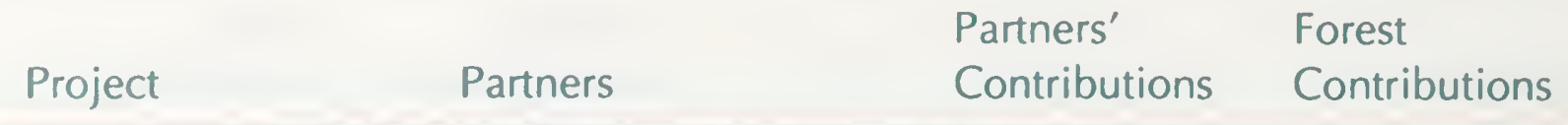

\section{Natural Resource Conservation Education (continued)}

\begin{tabular}{|c|c|c|c|}
\hline $\begin{array}{l}\text { Environmental } \\
\text { Awareness Days at } \\
\text { Moose Pass and Hope, } \\
\text { AK }\end{array}$ & $\begin{array}{l}\text { Cooper Landing, Moose Pass, } \\
\text { and Seward Elementary } \\
\text { Schools }\end{array}$ & (In-kind) $\$ 3,000$ & $\$ 3,000$ \\
\hline $\begin{array}{l}\text { Seward Parks and } \\
\text { Recreation Day Camp }\end{array}$ & $\begin{array}{l}\text { City of Seward Parks \& } \\
\text { Recreation Department }\end{array}$ & (In-kind) $\$ 500$ & $\$ 500$ \\
\hline Cordova Science Club & $\begin{array}{l}\text { Prince William Sound } \\
\text { Science Center } \\
\text { Bidarki Recreation Center } \\
\text { Copper River Delta Institute }\end{array}$ & $\begin{array}{l}\$ 3,500 \\
\text { (In-kind) } \$ 1,000 \\
\text { (In-kind) } \$ 1,000\end{array}$ & $\$ 3,000$ \\
\hline $\begin{array}{l}\text { Natural Resource } \\
\text { Conservation Education } \\
\text { for Prince William } \\
\text { Sound }\end{array}$ & $\begin{array}{l}\text { Prince William Sound } \\
\text { Science Center } \\
\text { ARCO } \\
\text { USDA Forest Service NRCE } \\
\text { Grants } \\
\text { Prince William Sound } \\
\text { Community College } \\
\text { Chugach School District }\end{array}$ & $\begin{array}{l}\$ 3,000 \\
\text { In-kind } \\
\text { In-kind }\end{array}$ & (In-kind) $\$ 2,000$ \\
\hline $\begin{array}{l}\text { Natural Resource } \\
\text { Conservation and } \\
\text { Environmental Education } \\
\text { Programs (Special } \\
\text { Groups and Events) }\end{array}$ & $\begin{array}{l}\text { Winter Tourism Fair } \\
\text { Corvallis School District } \\
\text { YMCA of Anchorage } \\
\text { Bird Treatment and Learning } \\
\text { Center } \\
\text { Anchorage School District } \\
\text { Sportsmans Show } \\
\text { Salvation Army } \\
\text { Serendipity }\end{array}$ & $\begin{array}{l}\text { In-kind } \\
\text { In-kind } \\
\text { In-kind } \\
\text { In-kind } \\
\text { In-kind } \\
\text { In-kind } \\
\text { In-kind }\end{array}$ & 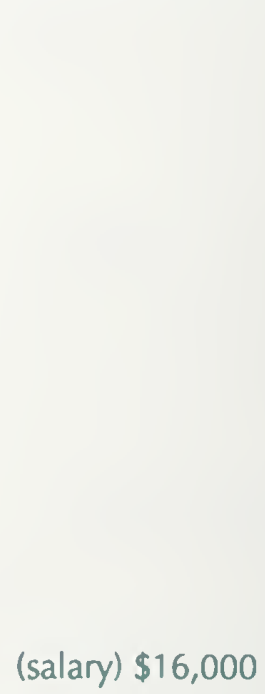 \\
\hline
\end{tabular}



Project
Partners
Partners'
Forest

Natural Resource Conservation Education (continued)

\begin{tabular}{|c|c|c|c|}
\hline & Anchorage School District & (FS paid) In-kind & \\
\hline & Sheldon Jackson College & In-kind & \\
\hline & Sitka School District & In-kind & \\
\hline & Alaska Pacific University & In-kind & \\
\hline & North Side School & In-kind & \\
\hline & Petersburg School District & (FS paid) In-kind & \\
\hline $\begin{array}{l}\text { Natural Resource } \\
\text { Conservation and }\end{array}$ & Tuskeegee Institute & (FS paid) In-kind & \\
\hline Programs (Schools) & Delta Junction Schools & In-kind & (salary) $\$ 15,000$ \\
\hline & $\begin{array}{l}\text { Prince William Sound } \\
\text { Science Center }\end{array}$ & $\$ 5,000$ & \\
\hline & $\begin{array}{l}\text { Prince William Sound } \\
\text { Community College }\end{array}$ & (In-kind) $\$ 3,000$ & \\
\hline & Cordova Public Schools & In-kind & \\
\hline & $\begin{array}{l}\text { USDA Forest Service NRCE } \\
\text { Grants }\end{array}$ & $\$ 3,000$ & \\
\hline & Copper River Delta Institute & $\$ 2,000$ & \\
\hline & Local Volunteers & (In-kind) $\$ 2,000$ & \\
\hline & $\begin{array}{l}\text { Alaska Department of Fish } \\
\text { and Game }\end{array}$ & In-kind & \\
\hline & ARCO & $\$ 9,000$ & \\
\hline Cordova Discovery & National Fish and Wildlife & & \\
\hline Room & Foundation & $\$ 8,000$ & $\$ 5,000$ \\
\hline
\end{tabular}




\begin{tabular}{lll} 
Project $\quad$ Partners & $\begin{array}{l}\text { Partners' } \\
\text { Contributions }\end{array}$ & $\begin{array}{l}\text { Forest } \\
\text { Contributions }\end{array}$ \\
\hline Natural Resource Conservation Education (continued) &
\end{tabular}

\begin{tabular}{|c|c|c|c|}
\hline & & \multirow{2}{*}{\multicolumn{2}{|c|}{ (In-kind) $\$ 1,000$}} \\
\hline & Moose Club & & \\
\hline & Local Volunteers & \multicolumn{2}{|l|}{ In-kind } \\
\hline & Elks Club & \multicolumn{2}{|l|}{ In-kind } \\
\hline & Cordova Times & \multicolumn{2}{|l|}{ (In-kind) \$200 } \\
\hline & U.S. Postal Service & \multicolumn{2}{|l|}{ In-kind } \\
\hline & Cordova Visual Artists & \multicolumn{2}{|l|}{ In-kind } \\
\hline & KLAM Radio & \multicolumn{2}{|l|}{ (In-kind) $\$ 300$} \\
\hline & Cordova Public Schools & \multicolumn{2}{|l|}{ In-kind } \\
\hline \multirow[t]{2}{*}{ Kids Fishing Derby } & Area Businesses & $\$ 500$ & $\$ 500$ \\
\hline & $\begin{array}{l}\text { U.S. Fish and Wildlife } \\
\text { Service }\end{array}$ & \multicolumn{2}{|l|}{$\$ 1,500$} \\
\hline \multirow[t]{3}{*}{$\begin{array}{l}\text { International Migratory } \\
\text { Bird Day }\end{array}$} & $\begin{array}{l}\text { Alaska Department of Fish } \\
\text { and Game }\end{array}$ & In-kind & $\$ 2,500$ \\
\hline & $\begin{array}{l}\text { University of Alaska } \\
\text { Cooperative Extension } \\
\text { Service }\end{array}$ & $\$ 5,000$ & \\
\hline & $\begin{array}{l}\text { USDA Forest Service NRCE } \\
\text { Grant }\end{array}$ & $\$ 5,000$ & \\
\hline 4-H Forestry Camp & local business leaders & In-kind & (In-kind) $\$ 3,000$ \\
\hline \multicolumn{4}{|c|}{ Public Information and Interpretation } \\
\hline $\begin{array}{l}\text { Search for Historic Plates } \\
\text { in Prince William Sound }\end{array}$ & $\begin{array}{l}\text { The Marine Academy of } \\
\text { Vladivostok }\end{array}$ & In-kind & $\$ 1,600$ \\
\hline
\end{tabular}



Project
Partners'
Forest
Contributions
Contributions

\section{Public Information and Interpretation (continued)}

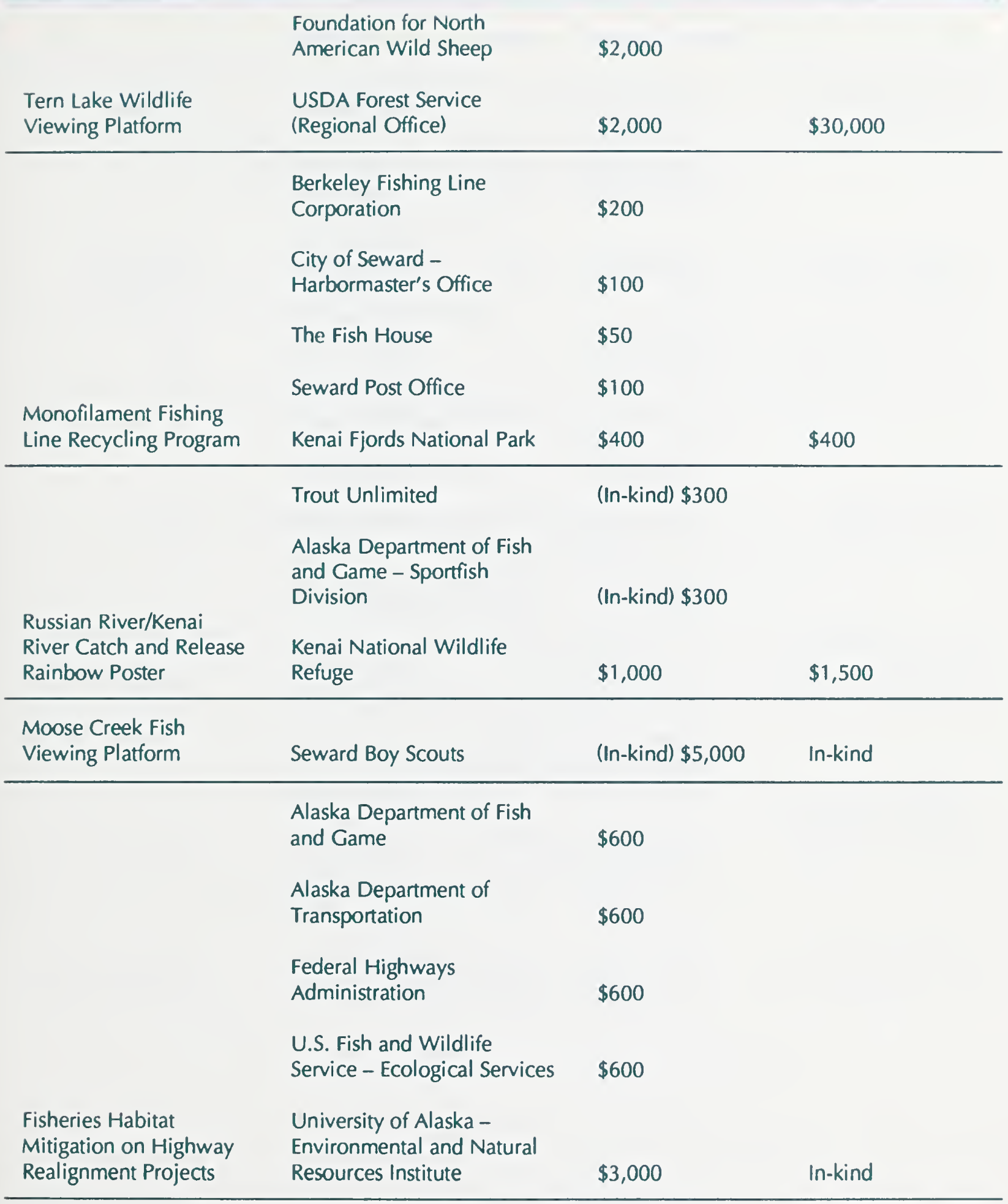




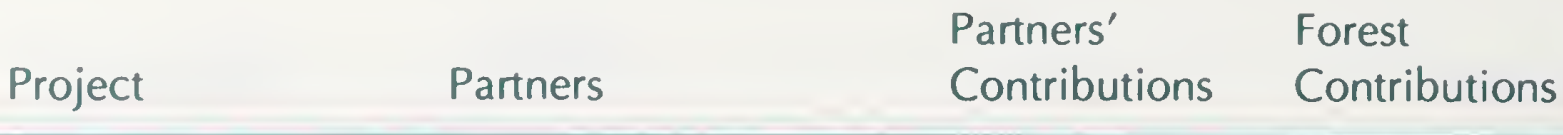

\section{Public Information and Interpretation (continued)}

Kenaitze Indian Tribe Interpretive Site

Kenaitze Indian Tribe

$\$ 53,000$

$\$ 118,000$

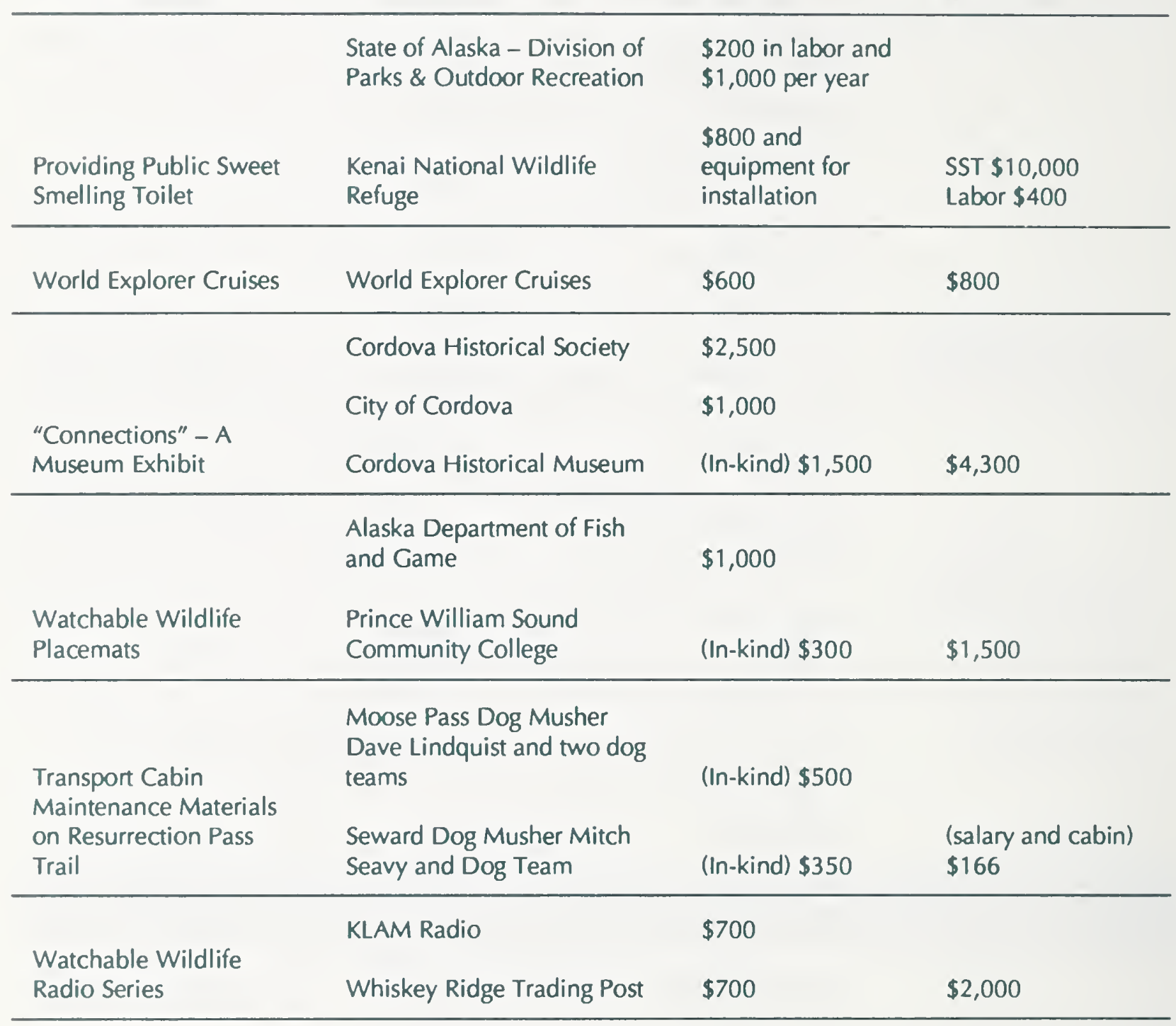




\begin{tabular}{lll} 
Project $\quad$ Partners & $\begin{array}{l}\text { Partners' } \\
\text { Contributions }\end{array}$ & $\begin{array}{l}\text { Forest } \\
\text { Contributions }\end{array}$ \\
\hline Public Information and Interpretation (continued) & &
\end{tabular}

Copper River Delta Institute (In-kind) $\$ 3,000$

Cordova Chamber of Commerce

In-kind

University of Alaska Fairbanks

(In-kind) $\$ 1,500$

Alaska Department of Fish and Game

In-kind

Prince William Sound

Science Center

(In-kind) $\$ 1,000$

Prince William Sound

Community College

(In-kind) $\$ 2,000$

Cordova Public Schools

In-kind

U.S. Fish and Wildlife

Service

In-kind

Anchorage Audubon Society In-kind

Bidarki Recreation Center In-kind

The Cordova Times In-kind

British Petroleum In-kind

USDA Forest Service, Rural

Development

$\$ 8,000$

Kelly Weaverling and Susan

Ogle

In-kind

Copper River Delta

Wrangell/ St. Elias National

Shorebird Festival

Park and Preserve

In-kind

$\$ 4,000$ 


\begin{tabular}{|c|c|c|}
\hline Project & Partners & $\begin{array}{l}\text { Partners' } \\
\text { Contributions }\end{array}$ \\
\hline
\end{tabular}

\section{Public Information and Interpretation (continued)}

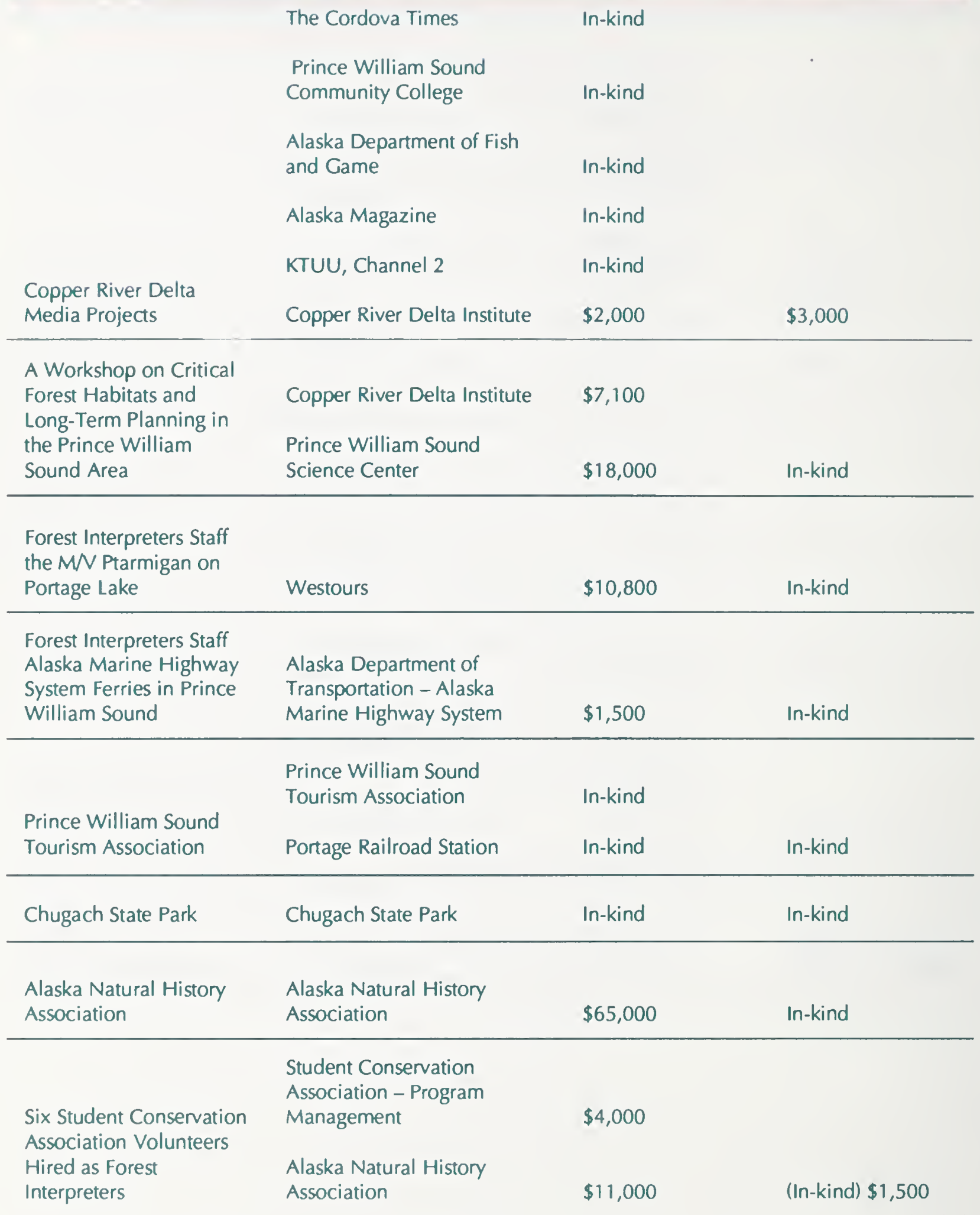




\section{Project \\ Partners' \\ Forest \\ Contributions \\ Contributions}

\section{Minerals, Vegetation, and other Partnerships}
The Role of Equisetum in Phosphorus Cycling and Net Primary Productivity on the Copper River Delta

Copper River Delta Institute In-kind

Yale University

$\$ 5,000$

Mellon Foundation

Copper River Delta Institute

$\$ 30,000$

In-kind

Pacific Northwest Research

Station

$\$ 5,000$

The Role of Nitrogen

Yale University

$\$ 5,000$

Fixation in Copper River

Delta Ecosystems

A.W. Mellon Foundation

$\$ 15,000$

In-kind

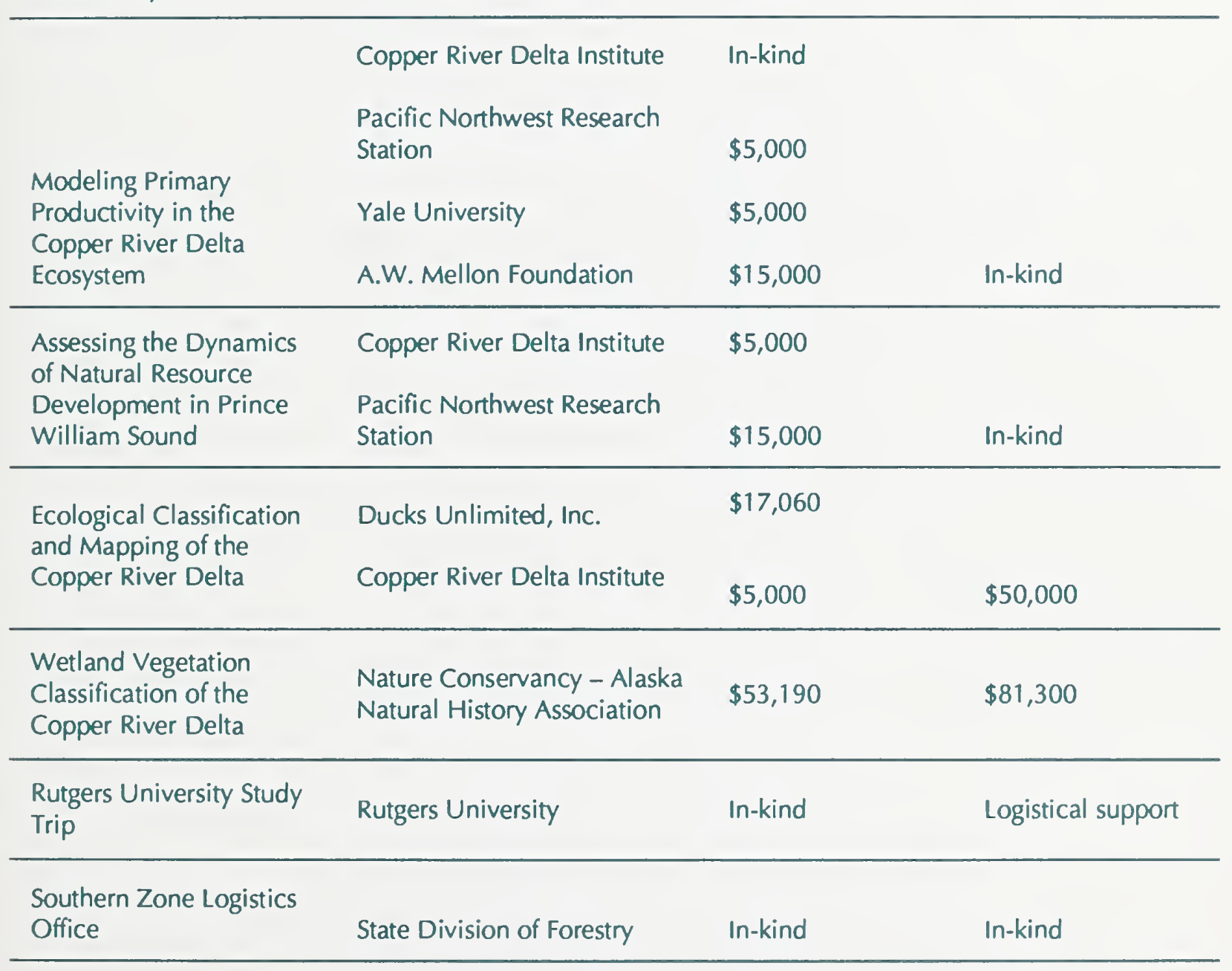




\begin{tabular}{|c|c|c|c|}
\hline Project & Partners & $\begin{array}{l}\text { Partners' } \\
\text { Contributions }\end{array}$ & $\begin{array}{l}\text { Forest } \\
\text { Contributions }\end{array}$ \\
\hline \multicolumn{4}{|c|}{ Minerals, Vegetation, and other Partnerships (continued) } \\
\hline Interagency Airtanker & Alaska Division of Forestry & $\$ 169,910$ & $\$ 10,000$ \\
\hline KAKM Channel 7 & KAKM Channel 7 & In-kind & In-kind \\
\hline \multicolumn{4}{|l|}{ Interagency Fire } \\
\hline & Grand Totals & $\$ 1,353,611.00$ & $\$ 968,862.00$ \\
\hline
\end{tabular}




The policy of the United States Department of Agriculture Forest Service prohibits discrimination on the basis of race, color, national origin, age, religion, sex, or disability. Persons believing they have been discriminated against in any Forest Service-related activity should write to: Chief, Forest Service, USDA, Washington, DC 20250 
